\title{
U⿴囗十⿱ 1922
}

VOL. $83 \cdot$ NO. $1 \cdot$ MAY 2010
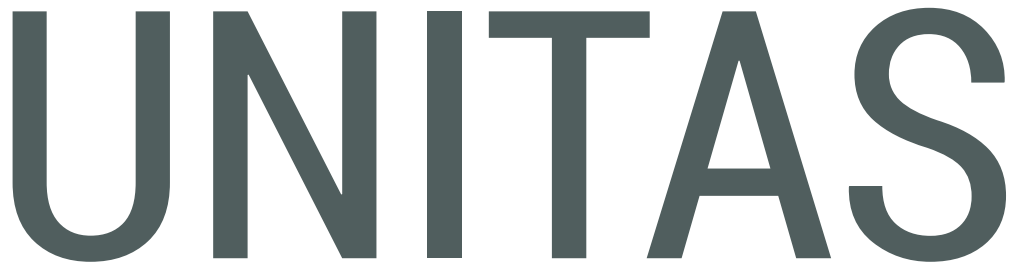

SEMI-ANNUAL PEER-REVIEWED INTERNATIONAL ONLINE JOURNAL OF ADVANCED RESEARCH IN LITERATURE, CULTURE, AND SOCIETY

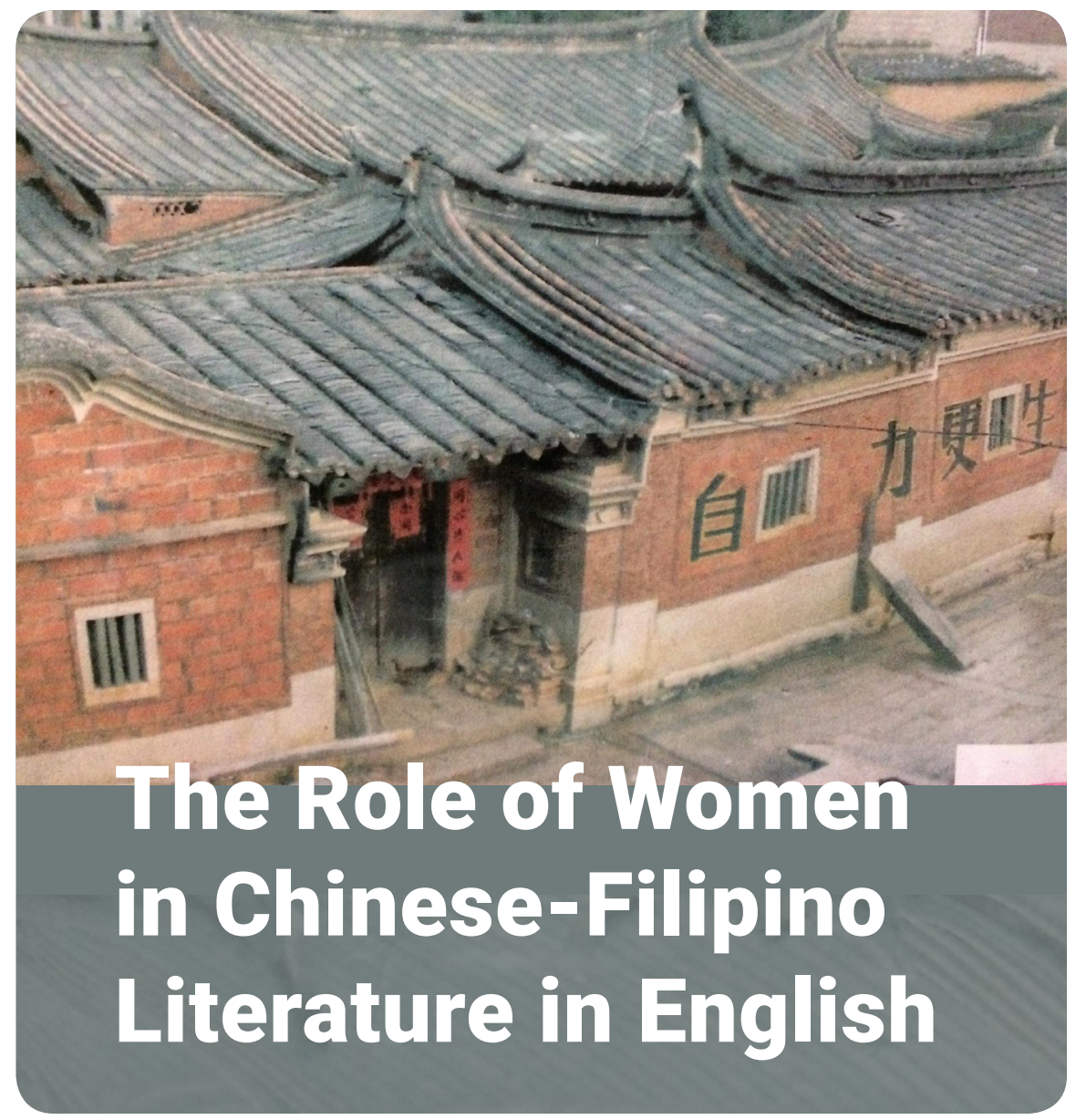

MARY JENNIFER J. QUE 


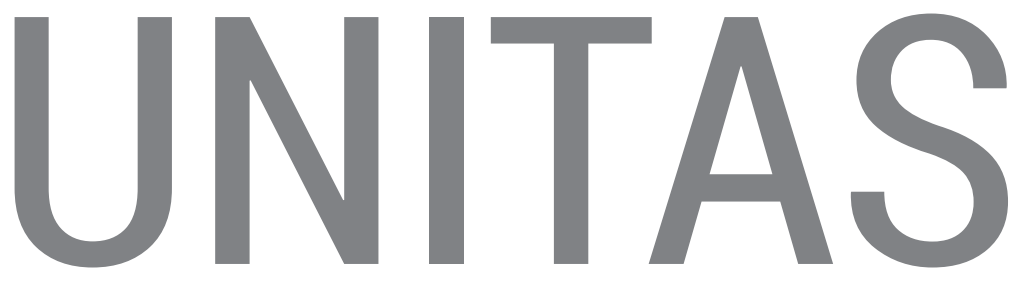

\section{The Role of Women in Chinese-Filipino Literature in English}

A Reader and Teacher's Guide 


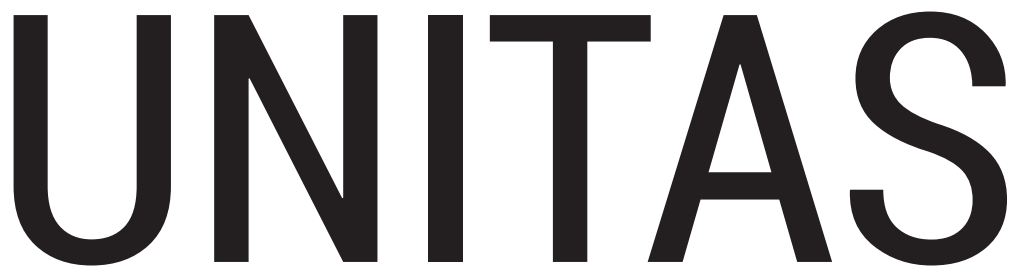

SEMI-ANNUAL PEER-REVIEWED INTERNATIONAL ONLINE JOURNAL OF ADVANCED RESEARCH IN LITERATURE, CULTURE, AND SOCIETY

\title{
The Role of Women in Chinese-Filipino Literature in English
}

\author{
A Reader and Teacher's Guide
}

MARY JENNIFER J. QUE
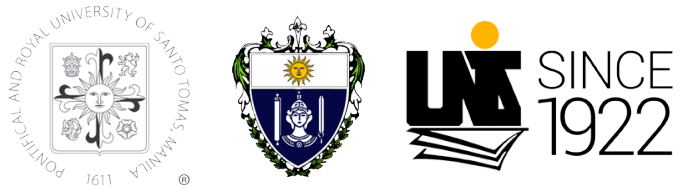
The Role of Women in Chinese-Filipino Literature in English: A Reader and Teacher's Guide

Copyright @ 2010 Mary Jennifer J. Que and the University of Santo Tomas

Layout by Paolo Miguel G. Tiausas UNITAS Logo by Francisco T. Reyes

About the book cover:

Photo taken by Mark Lange and used with permission as book cover.

The house in the photograph is that of the author's maternal grandparents' built in Nan'an, Fujian, People's Republic of China in the 1920s. The characters on the wall of the house when read as separate characters mean "self," "strength," "more," and "life." Altogether, they mean "self-reliance."

ISSN: 2619-7987

ISSN: 0041-7149 


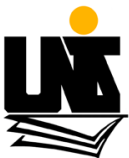

UNITAS is an international online peer-reviewed open-access journal of advanced research in literature, culture, and society published bi-annually (May and November).

UNITAS is published by the University of Santo Tomas, Manila, Philippines, the oldest university in Asia. It is hosted by the Department of Literature, with its editorial address at the Office of the Scholar-in-Residence under the auspices of the Faculty of Arts and Letters. Hard copies are printed on demand or in a limited edition.

Copyright @ University of Santo Tomas

\section{Copyright}

The authors keep the copyright of their work in the interest of advancing knowledge but if it is reprinted, they are expected to acknowledge its initial publication in UNITAS. Although downloading and printing of the articles are allowed, users are urged to contact UNITAS if reproduction is intended for non-individual and non-commercial purposes. Reproduction of copies for fair use, i.e., for instruction in schools, colleges and universities, is allowed as long as only the exact number of copies needed for class use is reproduced.

\section{History and Coverage}

Established in July 1922, UNITAS is one of the oldest extant academic journals published by a university in the Philippines as well as in Asia. Still, UNITAS is perhaps the oldest extant academic journal of its kind in the Philippines and Asia in terms of expansive disciplinary coverage and diverse linguistic representation through the decades. While always cognizant of disciplinary specialization, it has been "multidisciplinary" in publishing scholarship that is intra-disciplinary within the humanities and the arts, and interdisciplinary across the other disciplines. As it was in the beginning, it has aimed for "unitas" by conjoining disciplinary difference through its pages.

Moreover, it has been multi-linguistic on the whole, allowing itself to evolve from a journal published purely in Spanish, and then in English, becoming bilingual eventually in the various issues in which articles are written in Spanish and English, or 
as has been the case in the last several decades, in English and Filipino. And, of late, UNITAS has also published articles in other languages.

Apart from its disciplinary inclusiveness and crossovers, in almost 100 years of its existence, UNITAS has expanded the conceptual terrain of academic and topical coverage. It has published on cutting-edge and time-honored themes in which both established and emerging voices in research and scholarship are heard in articles that range across traditions, modernities, movements, philosophies, themes, politics, geographies, histories, musical types, architectural styles, gender relations, sexualities, government and non-government institutions, educational philosophies, media, forms, genres, canons, pedagogies, literary and cultural relations, and comparative studies, among others, in book review essays, critical commentaries, scholarly papers, and monographs. Such an expansiveness has allowed for establishing new lines of inquiry or exploring new lines of thinking about old ones.

\section{Editorial Policy}

UNITAS invites work of outstanding quality by scholars and researchers from a variety of disciplinary, intra-disciplinary, interdisciplinary and cross-disciplinary principles, protocols and perspectives for its readership consisting primarily of academics, researchers, and graduate students, as well as of a diverse public consisting of scholars and leaders who are at the forefront of their fields and advocacies, undertaking research on multidisciplinary aspects of national and global issues within and beyond academia broadly from the perspective of but not limited to the human sciences.

In general, UNITAS aims to publish leading-edge and challenging articles and monographs in regular and special issues in relation to the critical currents and themes of the nation, the Asian region and the world which try to meet the various problems and opportunities of today's globalization.

Although single-authorship of articles remains typical, UNITAS encourages the submission of papers that are co-written by authors working across multi-cultural and multi-linguistic settings, which have resulted from an inter-cultural, inter-regional or inter-national collaboration of researchers in an effort to internationalize knowledge production, circulation and reception.

In particular, under the rubric of literary and cultural studies in Asia, UNITAS aims to be a platform for ethically engaged studies that represent intersections of national and international literatures, arts and cultures, crisscrossing critical and creative categories, authors and readers, "East" and "West," "North" and" South," text and 
context, close readings and fieldwork, original works and translations, and theoretical and practical methodologies.

UNITAS welcomes submissions from all locations of the globe which are published in English, Philippine national and regional languages, and other foreign languages. Non-English language articles are required to submit an extended abstract in English containing the full argument rather than just a digest of the main idea.

Submissions to UNITAS are to follow the $8^{\text {th }}$ edition of the MLA Style Manual. During the evaluation process, unless otherwise recommended by the double-blind peer reviewers to use a different documentation format, articles must be published following the MLA guidelines.

\section{Ethical Policy}

Every submission is assumed to have not been previously published and is not under consideration elsewhere for possible publication, unless it is a major submission meant as a reprint, and later approved for publication as such.

Plagiarism is the copying of large blocks of texts of someone's work and representing them as one's own. If plagiarism is ascertained after publication, the article may be withdrawn or retracted. Self-plagiarism or or duplication of passages without proper citation will be evaluated on a case-to-case basis.

After the protocols of peer review and editing, UNITAS may or may not ask the authors to review the article prior to publication due to constraints.

Securing the publishing rights of all photos, images, or charts accompanying the article is the responsibility of the author.

Articles have to be submitted via e-mail to unitasust@gmail.com

Address all communications to:

University of Santo Tomas Office of the Scholar-in-Residence/UNITAS Office, Faculty of Arts and Letters

G/F, St. Raymund de Peñafort Building, España St., 1008, Manila, Philippines Telephone No: 406-1611 loc. 8830 


\section{International Editorial Board}

\section{Patricio Abinales}

University of Hawaii at Manoa, US

Syed Farid Alatas

National University of Singapore

Jonathan Beller

Pratt Institute, US

John D. Blanco

University of California, San Diego

Melani Budianta

University of Indonesia

Richard Chu

University of Massachusetts, US

Joel David

Inha University, South Korea

Fabian Antonio M. Dayrit

Ateneo de Manila University

Eduardo Deves-Valdes

Universidad Santiago de Chile

\section{Leonard Harris}

Purdue University, US

Caroline Sy Hau

Kyoto University, Japan

\section{Loren Kruger}

University of Chicago, US

Bienvenido Lumbera

University of the Philippines

\section{Pawit Mahasarinand}

Director, Bangkok Art and Culture

(BACC)

\section{Victor Merriman Edge}

Hill University, UK

Patrick A. Messerlin

Sciences Po, France

\section{Resil Mojares}

University of San Carlos

Cebu City, Philippines 


\section{International Editorial Board}

Mitsuya Mori

Seijo University, Japan

Tran Van Phuoc

Hue University, Vietnam

E. San Juan, Jr.

Emeritus Professor of Ethnic

Studies and Comparative Literature,

University of Connecticut

Stephen Shapiro

University of Warwick, UK

Inseop Shin

Konkuk University, South Korea

Brian Singleton

Trinity College Dublin, Ireland

Megan Thomas

University of California, US

Nicanor G. Tiongson

University of the Philippines
Lily Rose Tope

University of the Philippines

Ruanni Tupas

National Institute of Education,

Singapore

\section{Christa Wirth}

Universität Zürich, Switzerland

Paul Young

University of Exeter, UK

Nie Zhenzhao

Zhejiang University, China 


\section{Editorial Staff}

Maria Luisa Torres Reyes

maria.luisa.reyes@ust.edu.ph

EDITOR IN CHIEF

Joyce L. Arriola

ASSOCIATE EDITOR

Maria Eloisa S. Perez

ASSISTANT EDITOR

Nicole R. Tablizo

MANAGING EDITOR

Vae Ann C. Dadia

EDITORIAL ASSISTANT 


\section{Contents}

xiii Abstract

1 Introduction

9 Women in Chinese-Filipino Literature

144 Appendix 1: The Lesson Plans

159 Appendix 2: Note to the Teacher on the Different Teaching Techniques

$167 \quad$ Notes

168 Works Cited

172 About the Author 



\section{Abstract}

Chinese women have been traditionally viewed in three major roles-as a daughter, wife, and widow. According to the three obediences, which are ancient and imperial China's set of moral principles and social code for women, a woman had to obey her father as a filial daughter, her husband as a chaste wife, and her sons as a devoted widow. Imperial China, however, gave women a fourth role that of a concubine. This monograph examines the roles Chinese women play in society, and presents a compilation of six short stories and six poems written by Chinese-Filipino writers that depict these roles. The selections are restricted to those that focus on the ChineseFilipino woman's role in her family and in the community because gender roles are strictly delineated and prescribed in Chinese society. The selections are followed by study guides for teachers and students to guide them to watch for certain culturally-specific practices or nuances. These texts present the uniqueness of the Chinese-Filipino woman's situation as one influenced by her bi-cultural identity and her western-style education and upbringing.

\section{Keywords}

Chinese-Filipino women, filial piety, wife, daughter, widow, concubine, ancestor worship 



\section{The Role of Women in Chinese-Filipino Literature in English}





\section{Introduction}

Surveying the plight of women in China throughout its history, one cannot help but agree with prominent journalist-scholar Lin Yu Tang (1895-1976) when he commented that "something in the Chinese blood never quite gave women her due from primeval times" (137).

The low status of the Chinese woman has been generally blamed on Confucius' social philosophy, but this view is not totally valid. Confucianism, an ancient philosophy dating back to $6 \mathrm{BC}$, is held largely responsible for the Chinese pattern of close family ties and absolute rule. Confucius (551 BC-479 BC) believed that men would be willing to submit to others if this submission would result in peace. He codified this willingness in terms of five relationships: between ruler-subject, parent-children, brother-brother, husband-wife, and friend-friend, of which only the last is between equals (Welty 15). On the other hand, in Confucian thought, women are supposed to be subservient to the males in the family; she must follow her father, husband, and sons. 
Confucianism emphasized the distinction between superiority and inferiority; it stood for obedience, recognition of authority, and the division of duties between men and women (Lin 139). Since the Chinese woman was considered inferior to the man, it was she who had to cultivate the qualities of quietness, obedience, loyalty, and sacrifice to preserve Confucianism's goal-social harmony. Although Confucius gave the wife an "equal" place with the husband and motherhood an honored place in the family, later male scholars pushed Confucianism's distinction between men and women to such extremes that according to the Book of Rites, it was deemed improper for married sisters to eat at the same table with their brothers (Lin 138).

Feminine virtues like obedience and loyalty were codified by Liu Hsiang, the prominent son of the imperial family in the first century BCE, into something like feminine ethics quite distinct from that of the men.

Noted historian and poetess Pan Ch'ao, author of Women's Guide, was the great exponent of the "three obediences"-a woman was subject to her father from birth, her husband at marriage, and her son at widowhood (Lin 140).

When the Sung scholars came to power (960-1279 AD), women were further subjugated by the imposition of a secluded life: girls were hidden from the public eye and grew up with a coterie of female cousins, aunts, and female slave girls. During this period, men became so obsessed with female chastity that remarriage for widows became a moral crime. This obsession extended to the Ming Dynasty (1368-1644 AD) when chaste widowhood was officially rewarded with pailou [official titles] and exemptions from official labor service (Lin 141).

With the rise of great houses due to the accumulation of wealth during the Wei and the Chin Dynasties (220-420 AD), women were further oppressed when wealthy men took on concubines. A traditional marriage then required the groom's family to present betrothal gifts to symbolize prosperity and luck to the bride and her family; in return, the bride's family was expected to present gifts to the groom's side and to offer a suitable dowry for their daughter. The dowry and gifts from the bride's side should match the groom's family's gifts in order for her family not to lose face. These gifts 
must come in pairs and may include food items such as wine, oranges, and tea. Other gifts expected are gold earrings, bracelets, necklaces, and rings. Therefore, the practice of providing a daughter a suitable dowry and gifts for her groom's family became a burden many peasants found very hard to bear. Although the groom's family would have to pay for a son's wedding, sons would still be more valued than daughters because in the long run, sons would carry the family name. They could work in the fields and care for their elderly parents unlike daughters who, upon marriage, would be counted as part of their husband's family. During this period, thousands of poor peasants killed their baby girls out of fear for the future as wedding rituals grew more elaborate and expensive. It was not long before women were subjected to one of the most inhuman manifestations of oppression: footbinding (Gray 232).

\section{The Three Obediences In Ancient China (1600-221 BC)}

To paint an accurate picture of the Chinese woman, it is important to look at the three major roles she played in society: daughter, wife, and matriarch. However, imperial China (221 BC-1912 AD) gave women a fourth role that of a concubine.

According to the three obediences, a daughter is obliged to follow the wishes of her father concerning everything at all times. She is expected to cultivate the qualities of quietness, obedience, good manners, personal neatness, industry, and abilities in cooking and sewing. She is also subject to the painful process of footbinding as early as four years old. Although the bound feet were painful, unmercifully so during her growing years, she is expected to be grateful to her parents for subjecting her to this ordeal as a measure of their parental foresight (Lin 168). Since men consider bound feet as extremely pleasing and find the carriage and gait of women with bound feet as tantalizing, mothers bind their daughters' feet to assure her of a good match later in life. Their husbands approve this practice since their daughters' marriageability to a socially-prominent family would reflect his own family's prestige. 
Once married, the woman is then expected to shift her loyalty from father to her husband. Convention demands that she serves her mother-in-law with unquestioning obedience and devotion. She is, however, treated as nothing more than a slave to the latter's whims and is expected to endure it. This situation is plagued by disputes between the two, but a Chinese husband offers little help or consolation at all. Filial piety demands that he gives his loyalty to his mother rather than to his wife-the rationale being that unlike the mother, the wife is easily replaced. Faced with this condition, many wives resort to suicide just to escape their bitter situation.

To be a good wife then means being a totally submissive and obedient daughter-in-law. She can, however, improve her status by bearing a son; the more, the better. Since the perpetuation of the clan was of paramount importance to the elders, a wife unable to produce sons has to endure her husband taking on a concubine.

The last obedience is toward a son but unlike the first two, this stage in a woman's life is happy. Although her identity outside the clan is dependent on the prestige of her son's name, a matriarch's stature in the clan is supreme. At death, she receives the same honors paid by her sons to her husband.

\section{The Chinese Woman Today}

After thousands of years of seclusion, Chinese women now work alongside men, involved in all areas of life. This change started in 1911 when China discarded the monarchy, became a republic, and continued after the communists came to power. The May 4th Movement of 1919, a nationalist protest against the unfair treaties of the foreign powers after World War I, showed the first woman's movement as an independent organizational body (Snow 19). Through the following years, female students were in the forefront working for reforms and figuring prominently as nurses, party workers, and even soldiers.

In 1950, the Marriage Law proclaimed a new liberty for the Chinese women, announcing that " $[\mathrm{t}]$ he feudal marriage system based on arbitrary and compulsory arrangements and the supremacy of men over 13 women, and in disregard of the children, is abolished" (Clayre 80). 
For the first time in China, women were allowed to choose their husbands and divorce them if they so wished. Many men understandably resisted this law initially. Divorce meant division of property and for an ordinary farmer, this could result in economic instability or ruin (Clayre 80).

Unfortunately, the legal equality between men and women created in 1949 did not always afford women the equality they strove to get. In practice, women are expected to undertake the same duties as men in addition to their traditional household work. Moreover, centuries of bias against women are proving to be so well-entrenched that even today, much time and energy are still spent convincing parents and, with greater difficulty, grandparents, that a baby girl is as good as a baby boy (Clayre 82). Because of China's one child policy which punishes offenders with stiff fines and other penalties, many resort to killing their baby girls hoping to try for a son next time. This practice continues despite the clause in the Marriage Law which explicitly states that " $[\mathrm{d}]$ rowning babies and other acts of murdering girl babies are prohibited" (Clayre 83). Ironically, because of this situation, alarming and severe social problems are actually in store for those boys. Due to the uneven ratio of males and females, many of them will have difficulty looking for spouses in the future.

The Chinese woman today is indeed a far cry from the footbound slave of yesterday but Mao Tse Tung's often repeated dictum that women held half the sky still does not hold completely true in China today (Snow 3). Top level party slots are still comparatively reserved for men. Still, the situation is bound to further improve no matter how slow, owing to China's increasing contact with western ideas and standards. As more and more Chinese are exposed to other cultures through education and actual contact with other people, the Chinese woman will hopefully be given her rightful place in society.

\section{The Chinese-Filipino Woman}

Despite the delay of Chinese women's migration to the Philippines due to the travel ban by the Manchu Dynasty in the late 19th century, the Americans' 1902 Exclusion Act, and other historical constraints, there was no stopping 
the Chinese women from joining their husbands here in the Philippines. ${ }^{1}$ Wives of Chinese migrants wanted to join their husbands in the Philippines for a variety of reasons: to escape the poverty in their motherland, to be with their husbands and raise their families in a new land, and to escape the clutches of their mothers-in-law. The women ensured the observance of traditional ways and delayed cultural assimilation. Out of necessity, most women immediately helped in their husband's business or in running the store, unlike women in China who were cloistered. This exposure helped in the shifting of gender roles from being patriarchal entrenched to being bilateral.

Further influx of Chinese women migrants stopped between 1949 and 1975 due to the Philippine's recognition of Taiwan. However, the 1975 presidential decree of former President Ferdinand Marcos granting naturalization to many Chinese paved the way for their greater involvement in society. As a result of their naturalization, they gained greater exposure to the country's cultural environment which generally treated women as equal to men. Their naturalization also afforded them a college education which proved crucial in giving them greater economic and social freedoms.

Other factors also contributed to the change in the Chinese woman's role. Aside from their involvement in business and their western-style education, "the change in the pattern of urban residence has contributed to the shrinking of the extended family (Cariño, China and the Overseas Chinese in Southeast Asia 3). Without family elders meddling in their affairs, the Chinese-Filipino family is more receptive to external influences, especially the mass media, the school, religious organizations, and social clubs.

The Chinese-Filipino woman's sustained exposure to the Filipino way of life and her western-influenced education granted her "sharper awareness to the need to raise their status at least equivalent of Filipino women in general" (Cariño, China and the Overseas Chinese in Southeast Asia 3). Comparing her plight with her Asian sisters, the Filipino woman is indeed to be envied. The 1975 Commission on the Status of Woman describes her as: 
[n] either a fragile, merely decorative ornament on a pedestal nor man's downtrodden slave, the Filipino woman participates in activities that influence her home, community and social life. She takes part in making decisions, in earning and managing the income for her family; she takes leadership positions in revolutionary movements that affect national policy; she serves in private and public capabilities to attend to the social and economic needs of her country, even going further afield to contribute her share in the international world. The Filipino woman, therefore, is an active force in Philippine society (12).

More than most Asian women, the Filipino woman stands side by side with her Filipino male partner. The Filipino myth of Malakas and Maganda show her emerging equal to Malakas. Her situation may not be totally satisfactory; like all women worldwide, many are still locked out of the highest positions in politics, business, and social institutions simply on the basis of gender. Conflict inevitably arises in the Chinese-Filipino woman's life because of the competing claims of her family and tradition vis-a-vis her Filipino environment but as the selections in this Reader show, her capability to prevail over all odds shines through. 



\section{Women in Chinese-Filipino Literature}

\section{Preface}

According to Tulay, a monthly Chinese-Filipino digest which started in 1988, there are 121 Chinese schools in the Philippines with an approximate enrolment of 1.2 million students. Chinese schools refer to schools that offer mandatory Chinese classes, but they follow the mandated curriculum of the Department of Education. They are not considered international schools. Today, there are approximately 1.35 million Filipinos with Chinese ancestry. Great as this number is, most Chinese-Filipino students graduate without reading any piece of literature that deals with their bi-cultural identity and the problems that it engenders. Offering a reader where students and teachers can access texts on the Chinese-Filipino experience would afford the students a richer, more complete view of their reality-Chinese-Filipinos living in the Philippines receiving a western-style education and upbringing.

It is hoped that this Reader which includes a collection of literary texts that focus on a specific ethnic group, will help to answer a definite need for supplementary reading materials suited to senior high school and freshman 
college students. Specifically, it hopes to help Chinese-Filipino students understand themselves better within the context, and provide them a more holistic and pluralistic view of Filipino identity. Finally, this reader would address the lack in reading opportunities for Chinese-Filipino students and provide literature that deals with their bi-cultural identity and the problems that it engenders.

This Reader compiles six selected short stories: "Anais” by Doreen Yu, "Trouble in Beijing," “A Tropical Winter's Tale," "Woman of Am-Kaw," and "How My Cousin Manuel Brought Home A Wife" by Charlson Ong, and "The Burial” by Benito Lim-and six poems by Ma. Fatima Lim-Wilson"Mother Tongue," “Upon My Father's Calligraphy," "Father, in Old Town, Stockholm," "Ming Tombs," "Chinatown," and "Frost's Cabin"-all these writers are contemporary Chinese-Filipinos.

Because gender roles are strictly delineated and prescribed in Chinese society, the selections are restricted to those that focus on the ChineseFilipino woman's role in her family and in the community. These texts present the uniqueness of her situation as a Chinese-Filipino influenced both by traditional views and by a western-style education and upbringing.

Scholars have observed that among the peoples of the world, change comes painfully slow for the culturally-proud Chinese. Does the ChineseFilipino woman still have to draw her identity from her father, husband, and son at this day and age? To what extent have changes been effected? Is there room for further change? These and other questions are presented through the selected works of Doreen Yu (1953- ), Fatima Lim-Wilson (1961-), Charlson Ong (1960-) and Benito Lim (1937-). The main part of this Reader contains the selections followed by study guides. The questions are restricted to those that will guide the reader to watch for certain culturally-specific practices or nuances and will not include questions on the formal elements of fiction or poetry. There are two Appendices: the first contains four sample lesson plans to help the teacher present these selections in the classroom and hopefully to help students better understand themselves if they are Chinese-Filipino women and their Chinese-Filipino sisters 
if they are not; the second contains the explanation of teaching techniques employed in the sample plans.

\section{The Chinese-Filipino Woman As Daughter}

Chinese family solidarity is best seen in the relationship of its members. The father rules the family and during ancient times, he possessed the power of life and death over his children (Gray 233). The mother is accorded the same respect as the father and managed the affairs of the household. As seen in the poem from the Book of Odes, a son is clearly favored over a daughter. This is not to say that all Chinese daughters are unloved or uncared for. As children, girls may actually enjoy very close and affectionate relationships with their parents but the certainty of separation due to marriage prevented a long relationship between them. When she marries, she practically severs ties with her family and is considered part of her husband's clan. In a way, she is no more than a mere guest in her own home before and after her marriage. If she remains unmarried, she continues to be seen as a child in her parents' eyes no matter how old she gets.

The bias for sons is due to the Chinese regard for heirs who would continue the practice of ancestral worship. ${ }^{2}$ Since the woman is considered part of her husband's clan, her loyalty is expected to belong to her husband's family and not to her parents.

During ancient times, if a girl was born to a rich family, she was encouraged to learn how to manage a household, play a musical instrument, and cultivate the manners of demureness, obedience, loyalty, and submissiveness. She was secluded from men's eyes and lived among other women of the family. At around age five, she was subjected to the painful process of foot binding to assure her of a good marriage. If her family was poor, she may be exempt from foot binding since she was needed to work in the fields. On the table, she served her parents and brothers first, ate poorer fare or even leftovers as she was regarded as a "wasting asset" compared to her brothers who were "permanent investments" (Clayre 69).

Female infanticide among the very poor was common then, especially in the poor regions in the south. Since one more mouth to feed meant suffering 
for the whole family, poor parents drowned their babies or exposed them to the elements rather than risk the welfare of the other members of the family. Girls were regarded as too much of an economic liability; since she was to be married into another family anyway, what was spent on her is actually money wasted for the benefit of another family. Her future dowry would also be a heavy burden to her already impoverished family. If a baby escapes death, she may be sold to become a slave to a rich man's daughter or be a child-bride to his young son. Worse, she could be sold and end up a prostitute. In the words of a poem written by Fu Xuan in the third century:

How sad it is to be a woman!

Nothing on earth is held so cheap.

Boys stand learning at the door

Like gods fallen out of heaven.

Their hearts brave the Four Oceans,

The wind and dust of a thousand miles.

No one is glad when a girl is born;

By her the family sets no store. (Clayre 68)

A western-style education failed to discard old attitudes and afford her a more meaningful existence with her family. The following stories regarding Chinese-Filipino daughters present a clear picture regarding the tensions brought out by the conflicting claims of Chinese tradition and beliefs and western-style education and lifestyle. 


\section{"Anais" \\ by Doreen Yu}

Doreen Yu was born on November 16, 1953. She earned her Bachelor of Arts degree in English, magna cum laude, awarded the Philippine-British Society Scholarship for English Literature in 1973, and was also the recipient of a fellowship grant of the U.P. Writers' Summer Workshop in 1974. At present, she is an editor of The Philippine Star.

Actually, I heard about Ainee's death by accident. I was at the meat section of the supermarket one Friday afternoon when I overheard two ladies talking about it. I asked my mother when I got home, and through our corporation of aunties, got it confirmed Saturday morning. Yes, Ainee was dead. Her remains were at a funeral parlor downtown, to be buried at the Chinese cemetery on Sunday.

2 Ainee dead. It has always been hard for me to accept that someone I had known in life-someone I had talked to, laughed with, walked with-was dead and would never talk or walk again. I could hardly think of Ainee dead; Ainee who laughed a lot, talked even more. Ainee dead: it was hard to believe.

3 In spite of how much I hated funeral parlors, or memorial homes as they now call them, especially funeral parlors downtown, I dressed myself in a white shirt and black and white skirt and went to see her Saturday afternoon. Through the city traffic and occasional rain, I thought of Ainee.

4 Ainee and I were two of the many second generation overseas Chinese caught between the rigid traditional culture and the modern western influence. Growing up in a situation like that, in a place that was home and yet not really home, is not easy. It wasn't as hard for me since there was not much room for me to vacillate: strict parents and an even stricter grandmother taught me well enough where to draw the line and what kind of decisions to make. Ainee had lenient parents who probably were so confused, if not more so, than she was. Rules never held for long in that family of eight children: though the eldest daughter started 
wearing make-up at 18, the younger girl insisted on false lashes at 16; though that eldest son learned to drive at 21 , the younger boys learned at 15 and wanted cars at 18 . Sometimes the parents gave in, other times they didn't, depending not on reason or conviction, but on how strong or weak their defenses were.

5 As a child, Ainee gave them little trouble. She didn't demand much since I, her best friend and constant companion, did not have much for her to want to demand from her parents. We were the salingpusas in a mile-long game of patintero, the patients when the older children played doctor, the frightened passengers when our elder brothers went careening along their bikes through the streets of the less populated area of the city where we lived.

6 We went to kindergarten in the neighborhood Chinese school together, then we went on to grade school and graduated side by side six years later. By that time we had passed from Chinese jackstones to Nancy Drew books to shared secrets about boys.

7 The next year I transferred to a non-Chinese school for citizenship reasons. She stayed on in the Chinese school, envying me and complaining about the drudge of the old school. A few months later her family moved to another part of the city, and the next year she went to a non-Chinese school near there.

8 In spite of the promised daily phone calls and weekly visits, schools, new friends, and the general business of living became too much. The daily phone calls became weekly, then monthly, then hardly at all. Until the time when our friendship consisted of sending regards through mutual friends and relatives.

9 Somehow I don't remember feeling pain of parting or lost friendship when Ainee left. I had easily found new friends to share my interests and my secrets with. I don't even recall ever really missing her.

10 The last time I saw Ainee was at the birthday party of my fifth aunt about two years ago. We were both college sophomores; she at the coeducational university and I at an exclusive girls' school. She talked of my pakihanap exclusive school as being a "cloistered stifling institution of 
non-learning" rather than a place where one can "expand the horizons of the mind and learn to search for the true essence of life, not merely existence.” Her name was no longer Ainee, she was called Annie, or sometimes Anais, after "the lady in the movie who typified her kind of meaningless existence by an absurd death in a church."

11 Funny now, how I can remember her words very clearly. I also remember I had hardly anything to say to her. I had thought we would chatter endlessly about the years we hadn't been in touch, about what we did and the friends we had... instead I found someone straight from a movie on Haight-Ashbury, an old friend I could not even carry on dinner table conversation with.

12 And now she was dead. Maybe for me, Ainee had stopped existing long ago. Somehow I didn't feel sad; there were no tears. Just a sense of apprehension, anticipation and uneasiness as I saw the flower stalls and shops that cater to Chinese funeral practices lining the narrow crowded street where the funeral parlor was.

13 The driver told me to go down as he had found a place to park and did not intend to lose it. An odor of flowers and horse dung greeted me as I got out of the car. I felt nauseated, and wanted to get back in the car, but the door slammed shut and the car moved away.

14 I wove my way through flower wreaths and cloth streamers with Chinese characters and people in black and watch-your-car boys playing on the sidewalk toward the office to ask which chapel Ainee was in. Two doors before the office I recognized three of Ainee's uncles in a huddle. I went closer and heard them talking about the glass pane on the top half of the door and saw some cousins, some aunts, and a few other people in the poorly lit room. A strip of dark blue cloth with a dozen characters in white was posted on the door, but my grade six Chinese only recognized the three characters that was Ainee's name. A piece of black cloth hung from the top of the door and fluttered a few inches above my head. I took a deep breath and pushed the door. As I stopped inside the door slammed shut with a disrespectful bang. Some of the people turned. I didn't know whether to smile or not so I didn't. I looked for a more-than-familiar 
face among the familiar faces of Ainee's extended family, and finally saw her older sister at one of the back pews, talking in a whisper to a man I didn't recognize. While waiting for her to finish so I could talk to her, I looked around the stuffy air-conditioned room. The figures, mostly in black and dark blue, were huddled in groups according to age and sex it seemed. Some young men, cousins, if I remember right, were drinking cokes, while older ladies, who else but aunts, were sipping hot tea from coarse teacups. Aside from her older sister, I saw none of Ainee's other brothers or sisters, not even her parents.

15 Then I saw the coffin. It was in the front part of the chapel separated by a glass partition with a two panel door in the center. The bronze casket was on a metal stand on an elevated dais. At the front of the pedestal was a huge photograph of Ainee taken quite a few years ago. Incense sticks burned continuously in a small clay pot in front of the photograph. On both sides were bowls of food, and some fruit. On the extreme right, after a bunch of bananas, was a miniature car of orange and gold paper and in it were a pair of shoes and some clothes. On both sides of the coffin stood two gaudy candleholders each with three burning red and gold candles.

16 To the right of the door, in front of the dais, was a big earthen pot, the kind comic-strip Africa natives use to boil people in. This one was almost filled with ashes, and a fat lady sat in front of it, folding what appeared to me squares of colored paper and casting these into the pot. As I was wondering about that, Ainee's sister Lily came over to me.

17 "Dina, how nice of you to come," her voice was as soft as before with a slight trace of an American accent. She wore a black dress, as black as her shoulder-length hair. She was as fair, slender, and delicate looking as she was when Ainee and I used to watch practising her ballet.

18 "I heard about Ainee only this morning. I came as soon as I could. I'm very sorry," I said mechanically, not really feeling very sorry.

19 "Yes, thank you. It is a terrible thing, isn't it? Mama is very upset. She's at home right now, resting. Papa is still in the office. My other brothers 
and sisters will be coming in a short while. Everyone was. "Ah... would you like to...?" She motioned to the front.

20 I looked at the casket shining in the golden candle flames, at the burning incense at the fat lady forever folding and tossing paper. I thought of the nights ahead that I would not be able to sleep peacefully without Equanil. But I was already there and I had already seen the morbid sight of a Chinese funeral wake, so I nodded and followed Lily towards the glass door.

21 As she opened one side of the door, a strong wave of heat and incense hit my face. I coughed and felt rather sick, but walked in as Lily stepped up the dais and stood before the coffin.

22 I walked up and stood beside Lily. I took a deep breath and looked down at the white satin cloth that framed a face I almost didn't recognize. Looking again, I saw, except for a darker tan, the pudgy nose, the small mouth, the long lashes and the bushy brows of the Ainee I walked four blocks to school with, a number of years ago. It was the same face but I felt something was very different. Somehow, gone was the carefree vivacious expression that made the toss of the head and flash of teeth and smile the very picture of joie de vivre. In its place was a kind of tension, grimness that quite jolted me. I started at the face through the yellow dancing light reflected on the glass pane, and wondered whether this was the friend I had come to see.

23 I thought of the Ainee I met two years ago at the party. The one that spoke of existential dilemmas and absurd deaths and stifled minds.

24 "We... Ainee and I... just lost touch through the years somehow. I always meant to call or visit, but things always came up, as they usually do, and I just never did. I often thought of Ainee though..." I fumbled feeling the need to apologize, not really to Lily, more to Ainee who lay so still in the white satin under the glass pane.

25 Suddenly the candles and the incense and the wreaths behind the coffin came back as a big flame burst out behind me. I turned, startled, and saw that the fat lady had lighted the pot and the paper she had been folding caught up in a blaze. It died put almost as suddenly as it burst 
out in flames, and the fat lady sat down again and resumed her folding. I didn't want to ask what that was, but as we walked down, Lily explained, “That's money, sheets of silver and gold. It's being offered for Ainee."

26 I looked at her without a word as we re-entered the air-conditioned room. The people in the front pews stared at us. "You know how Mama is when it comes to customs. Although Ainee was a baptized Christian, she wants to follow all the Buddhist funeral customs. Look at the food. It is changed four times a day for offering. We had to clothe Ainee in seven satin suits and buy a pearl ring for her index finger." She sounded a bit exasperated.

27 “Yes, I know, your mother has always been very traditional," I wondered how Ainee would have reacted to all this.

28 As we reached the back of the room, Lily motioned me to sit down. I slid into an empty pew and she sat down beside me. I then asked the question that had been bothering me ever since I found out about Ainee's death.

29 "What happened? This is so sudden. I heard it was a car accident."

30 "Yes," she sighed. She ran her hand through her hair and the sparkle of the diamond ring on her finger caught the dull yellow light of the metal chandelier overhead. "Dina, I'm going to tell you this because you're a family friend and you were very close to Ainee once." The last word sounded mixed with reproach."Ainee's life is something very painful for us, something forgotten... until this happened. It's a terrible thing for the family. Mama's health isn't good and Papa has a lot on his mind. These last few years, Ainee's been nothing but trouble it seems..."

31 "Lily, I appreciate your telling me this. I know a family tragedy is difficult to bear, even more to talk about, but I do care for her a lot," I said convincingly, touching her arm with assurance.

32 "Yes, we all do care for her, one way or another." She sighed again. "You might already know that Ainee left home two months ago. Before this, it's been night after night of arguing and fighting with Mama and Papa and all of us. She complained about everything and she said such things. 
We don't know where she got her ideas. She sounded almost like a... a... communist..." she spat out the word.

33 "I'd better start from the beginning, if there is such a thing. Not long after we moved, she went to this school near our house. She was all right at first, happy that didn't have to study the double load of English and Chinese anymore. Then First Brother and I went to America and she was a junior, she seemed to change. She became bitter, cynical, always angry about everything we did particularly about the way we lived. We thought it was part of growing up, so we tried to be patient with her. Then she started coming home less and less-she would leave early in the morning and come back late at night. We talked to her, scolded her, but she didn't care. We don't know what she did; we tried to find out but couldn't for a while." She paused.

"Well, we soon found out that she had joined a political group and was attending rallies and all that. Of course, Papa was very angry, I remember they had a long fight one night, and well, after that, Ainee was home more often but she was still bitter and angry all the time, maybe even more so. She graduated from high school and that summer, Papa was going to give her a trip to Hong Kong as a kind of graduation present but she refused. Instead, she went on a tour of the south with some other students. Naturally we all didn't like the idea, but well, it was a school activity and the principal assured us it was all right. Besides she insisted and we couldn't really stop her." Lily sounded confused, uncertain, as if trying to convince herself about what she was telling me.

35 "She went to the university after that. She was taking nursing at first, but then late in her first year she joined an artist's group and shifted to A.B. She went around with some painters and poets or people who called themselves that. Then she became some kind of philosopher. She talked continuously about the meaning of life and searching for the true essence... Oh I can still remember some of the things she talked about."

36 "Yes, I remember she seemed so... different at Fifth Aunt's party..."

37 She continued as if she didn't hear me. "But at least this time she wasn't bitter or angry anymore. She didn't hate Papa for being a businessman 
or us for buying new clothes, as she used to. She went around in jeans and t-shirts and joined workshops and had paint splattered all over, but she did well in school and worked very hard at her painting and her writing. In fact she even gave me a beautiful painting for my wedding last year. For over a year, maybe even two years, things seemed to be tolerable, if not all right, with Ainee.

38 Now Lily sounded tired. I felt it was my turn to say something, but I didn't know what. As I opened my mouth to speak, she continued.

39 "Then, a few months ago, sometime last summer, we found out that she was sick. She lost weight and didn't eat much, and she complained about a lot of things... dizziness, nausea... She had only a year to go before graduation, but Papa thought it best to send her to First Brother in America for a rest before she continued school. It certainly was for her good, and we thought she would be happy about going, but she was just the opposite. She got angry, said she wouldn't go, and started hating us all over again. We fought a lot of the time. I'd ask her to be reasonable and she'd call me liar and a hypocrite and all sorts of things. Then she even refused to go to the doctor here. Not long after that, about two months ago, she left home. One morning she just disappeared. When we got up, she was gone. Some of her clothes were gone but she didn't leave a note or anything. We didn't want a scandal all over town, so we hired detectives to look for her but they couldn't find her. Her artist friends never had any addresses, or even last names, and we just didn't know where to look. Then Mama became ill, and Papa got so angry he just decided to stop looking for her. Of course we couldn't really forget her, and we still looked." She looked at me blankly and I hoped my face showed concern.

40 "About three weeks ago, I learned that she had moved in with this hippie poet or something in some kind of apartment above a beer house near the university. I went there but she wouldn't talk to me, wouldn't even see me. We all tried to see her, all of us children I mean. We didn't let my parents know. Mama was ill and Papa would get so angry I didn't know 
what he would do. But I left my address and my phone number, at my house, not Mama's, plus some money for her, but she never called.”

41 Lily seemed to tense up as she went on. "Then last Wednesday night, I got a call from one of her friends. It was late, about eleven o' clock, when this girl called and said there'd been an accident, a car crash, and Ainee was in the hospital. At first, I thought it was a joke, maybe they wanted money. But she told me to call the hospital and check. I did and it was true. Bill, my husband, drove me over. I didn't dare call home first. I wanted to see how she was first. When I got there she was already dead. I didn't see the body. Bill said the lower half was crushed...” She stopped, sounding terrified, as if it happening again. I put my arm around her to comfort her.

42 "I'm all right," she said, wiping tears away. "You see it's just so hard to call Second Brother, and the next morning we told the family. Mama almost had an attack. Second Brother made all the arrangements, and Mama and the aunties wanted all the traditional practices, so... I... Second Brother... asked her friends not to come. We're so afraid that Mama will have a second attack. She's not well but she wants to stay here all the time. Last night we were able to get her to go home to rest, but she'll be back for the Mass later. Last night, while Mama wasn't here, Third Brother went to pick up a few of her friends. They were here for only a while. I don't know if they'll come for the funeral. Third Brother says the one... the man she was... wasn't here. In a way maybe it is better he didn't come. Papa was very angry..."

43 She didn't go on. The man whom she was talking to earlier came up and gave her some tea. I presumed he was her husband. Lily was crying and I didn't know what else to say. The man asked me to leave her, so I moved to the pew across the aisle.

44 I thought over what Lily had just told me. I wondered what had happened, what had changed Ainee so much. I understood how Lily felt. It was hard to believe, harder even to accept as happening to a sister.

45 I was still thinking it over when I noticed someone at the other end of the pew I was in. It was a young man, in a white t-shirt and blue jeans. 
I wondered who he was. Perhaps he felt my stare, for he turned to look at me. We stared at each other for a long time. I seemed to recognize the face, then did not believe who I recognized. the funeral the next day. Outside, the air was hot and the stench from the gutters mixed with the scent of flowers and the setting sun. I looked for George and saw him at the corner, near the office I had intended to go to earlier when I came. I walked over to him and we went to the small sitting room next to the office. No one else was inside.

63 "Dina, I really have to go." George protested.

64 "George, tell me something. Were you the one Ainee moved in with?" He looked at me. I stared back at the former intercollegiate chess champion, the one the girls drooled over and stepped on each other to get a dance with at parties. We had worked together in several projects and got along well as friends since we had both decided we weren't each 
other's type. What was he now? I wondered but didn't ask. "You haven't answered my question."

65 "Why should I?" He became angry. "It doesn't really matter much whether she moved in with me or not. Fact was, her family was sending her away, throwing her out. She had nowhere to go. We accepted her, gave her a place to stay."

66 "But she was sick. Her family wasn't throwing her out. They were sending her to the States for treatment."

67 "Why couldn't she be treated here? There are doctors and hospitals here too, you know? Except that here, people might talk, and they'd lose their precious reputation!"

68 "What do you mean? What was wrong with her anyway? Lily didn't say."

69 "Isn't that just like them? Didn't say, did she? Well, I'm talking about heroin, and gonorrhea. Yes, addiction and VD. That's Ainee's sickness."

70 "Heroin? But how...?" I was shocked.

71 "She got hooked long ago. And I don't really blame her, with her kind of family..."

72 "But the VD. Where'd she get...?"

73 "She got it from some creep who took advantage of her. Said he'd get her writing published." He slammed his list on the wall.

74 "But, she didn't die of...did she?"

75 "No, it was a car accident. She was all excited about it, said she was going to meet some hotshot writer or another. She died on the way." I saw tears in his eyes. He started for the door. "I'll see you, Dina. Take care of yourself....”

(Focus Philippines 20-21, 24-45, 28-29) 


\section{Guide Questions:}

1. Ainee and Dina are second generation overseas Chinese "caught between the rigid traditional culture and the modern western influence" (par. 4). Would there be any significant change if this story happened:
a) In China?
b) In Taiwan?
c) In a country with a big Chinese population like Singapore?
d) In a Philippine province?

2. List the traditional Chinese values or customs you see in the story. How do these contribute to the conflict?

3. The Chinese regard filial piety as one of the most important values in life. To what extent is filial piety expected of Ainee? What Filipino value would you consider as its counterpart?

4. In paragraph 12, Dina declares that "Ainee had stopped existing long ago." Exactly what does she mean? Can it refer to something else?

5. Pearls are believed to possess magical powers and are regarded as charms against fires. During Ainee's funeral, she was dressed in traditional burial clothes and traditional practices regarding death were also observed in her honor. Discuss the irony of this situation in light of her wasted life. 


\section{"Trouble in Beijing" \\ by Charlson Ong}

Charlson Ong studied at Xavier School and the University of the Philippines. He has won several prizes for his short fiction from the Carlos Palanca Memorial Awards, Asiaweek, Philippines Graphic, and the Philippines Free Press. His first short story collection was given the National Book Award for fiction in 1990 by the Manila Critics' Circle. He is a journalist for some time and a writer for television.

He has packed his Chinese version Lutheran Bible this time. Conversion to Protestantism during his old age seemed to be Father's final affront against Mother's Buddhism and the Catholic upbringing of us children. The old termite-ravaged Kuomintang flag could be unfurled at Tiananmen Square at the "crucial moment." And certainly, the vintage WWII issue .45 calibre pistol may come in handy if things really got ugly. A duffel bag and leather attaché case have been sitting in our living room since early morning. Father's finally gotten his reluctant travel agent to book him on the next flight to Hong Kong where he plans to sneak into the mainland since direct flights to China have been cancelled as political tension heightened. "Wait till things settle a bit, Ah Bien." Mother pleaded. But save for the travel visa he hopes to secure from the Chinese embassy later this afternoon, my father is again packed and set to "reconquer the mainland."

2 With the rest of the world, Father had watched curiously the growing student-led popular movement in Beijing which the foreign press had dubbed as being "pro-democracy." Curiosity turned into excitement as the masses of demonstrators occupying Tiananmen Square swelled. He was exhilarated, awaiting every bit of satellite-fed news from China. Hope became trepidation as conservatives gained the upper hand in the government power struggle and as enthusiasm waned and police crackdowns began, there was anger in Father's eyes before he wept. He actually wept. Those he'd certainly deny me should I, his daughter, drop dead here and now. 
3 “He wept, Mother," I bleated like a goat, then, quite unable to hold back my own tears. "He wouldn't even show up for Roger's funeral and now he weeps for strangers across the Pacific Ocean."

"White hair cannot bury black hair," Mother replied for the umpteenth time, explaining how Chinese parents aren't supposed to send their children to the grave.

5 Father came to Manila during the 30 s to help market his uncle's silk, textile, and foodstuff imports from China across the Philippine Islands. By the end of the Second World War Father had made enough of a fortune to return to Amoy and set up a trading post for coconut products from Manila. In fact, he'd begun refurbishing the ancestral home in preparation for our eventual return when Mao marched his armies into Beijing and short-circuited Father's plans. Not that he loved the Kuomintang any better but Father simply hated the communist more. It was an absurd hatred seemingly beyond ideology and politics, a personal score that has yet to be settled. I remember Mother relating to us kids once how Father was arrested by some overzealous communist youth league when he returned to Amoy in '49 amidst civil war chaos to try and bring out Grandmother. But the old woman was too weak to travel and Father was detained by this band of militant youngsters demanding that he unload his "foreign gold hoard." Father never talked about this incident, although years later I'd guessed that the callouses on his back had to do with those times. Even after travel restrictions. To China were lifted back in the '70s, Father wouldn't hear of us visiting the place. He wouldn't touch any merchandise from the mainland even as our dry goods competitors were bringing in abalones, mushrooms, preserves, and other delicacies in demand in the local Chinese community.

6 "There are no communist mushrooms, Father." I remember Roger raising his voice once in desperation. We later shifted to textile and garments from Taiwan although, lately, mainland merchandise are again gaining on the market. Father's semi-retired, though, since suffering a mild stroke six years ago, my cousins and I mostly run the business. 
7 Father frequents Taiwan and Hong Kong which he calls "free Chinese" territories. He has an uncanny way of timing "business meetings" abroad to coincide with important family matters at home. Two years ago he missed Roger's funeral for a property auction in Hong Kong. Although he might have been holed up in some local five-star hotel for all we know.

8 Since the student movement began in Beijing a month ago, Father's entire existence has revolved around news from China. You didn't try conversing with him unless it concerned the latest developments on the trouble in Beijing. He fired off letters to Chinese language dailies denouncing the communist leadership in Beijing and supporting the "patriotic youth." He even went around soliciting funds for the movement from kin and associates.

9 I don't think Father will make it to China, at least not until the political situation normalizes. No one in his right mind will issue him a visa to that country at this hour and I'm sure Mother knows it, too. But she chooses to play his game. Mother's great at playing Father's games.

10 It's not that I don't care about Chinese students being roughed up by their police. For I too am routinely concerned with the plight of workers being tear gassed in South Korea, blacks being lynched in South Africa and gorillas being hunted down in the Kenyan mist. But for the life of me, I cannot fathom this sudden concern for freedom and "human rights" in someone who insists there are "technically" no political killings in the Philippines.

11 When I was picked up by the military years ago on the campus where I was associate editor of the school organ, Father did nothing to help me get out of detention although I knew he had a couple of generals in his Christmas mailing list. It was Mother who visited me every day and finally pulled enough strings to set me free. The old man thought detention would teach me some lasting lesson.

12 "So you think washing latrines is the worst thing they can think of," I remember shouting at him in exasperation a week after my release just to break that consuming silence that has since come between us. But 
he was deaf to my anger and has hardly been a presence in my life ever since.

13 So much has happened since then and Father certainly has had more than his fair share of pain. Still why am I convinced that he is again running away? Because Father thinks I'm marrying Hilario Brill in less than three weeks and it would be quite convenient for my old man to be fighting for democracy in China just when he is supposed to be giving me away in church.

14 Father doesn't seem to like Larry. He doesn't seem to like anyone since Roger died nearly two years ago from a malignant brain tumor Father insists that Roger would still be alive if Mother had consented to send him to China for acupuncture and chi kung treatment which is supposed to work wonders. But Roger had gone into coma two weeks after experiencing those crippling headaches and the doctors assured us that nothing could be done for him anywhere-even in Texas where Uncle Soo, Father's cousin, sits on the board of some expensive hospital.

15 Roger, four years my junior, was Father's only son. This preference for male heirs among the Chinese used to bother me, too, and I tried desperately to find common cause with my bereaved parents. But Roger was Father's progeny and his loss was something I'm not supposed to comprehend. That, I guess, is what Father has been saying to me all this time through his silence and evasions.

16 Larry's much older than me. But that fact didn't matter to my parents as much as his being a purebred Pampanggo. Women in our clan have had to marry grandfathers back in the mainland when circumstances warranted. But this would be the first time in eight hundred years that a daughter of the Lim's would be marrying a non-Chinese person, a huanna.

17 "It's 1989, Mother, "I'd say as if such dates mattered to people for whom the fate of the universe is inexorably tied to family history; people who are wont to recall, for instance, "the year of the great flood, when our patriarch Lim Bao became Minister of Rites in the Court of Emperor Chien Lung...” 
18 I've known Larry for over a year since meeting him in an introductory session on Transcendental Meditation and we've been dating for six months. He is the editor of a left-leaning weekly journal to which I contribute occasionally. Perhaps things would have been more difficult for us if Roger hadn't died. Father would still be quite vigilant in protecting the purity and honor of his progeny - on all fronts - and my marrying a non-Chinese person would have constituted a major tragedy. Now, I guess he couldn't care less if I eloped with a Martian. I think Mother saw this, too, and let go. What really bothers her is the fact that Larry has a sixteen-year-old son by a former lover. But when Mother realized that I'd been sleeping with Larry, marriage suddenly loomed as the lesser of evils. Mother's from an age where its virginity or death for single women no matter if they were raised to be concubines. I think she'd have gone bonkers if she knew Larry wasn't my first. But what she doesn't know won't hurt her.

19 Father thinks Larry is some kind of communist. He was among a group of a students who entered China back in 1970 but left after a year. I warned Larry against telling Father this and he did avoid discussing the matter when I invited him home for dinner once. But Larry kept on about the Proletarian Cultural Revolution being the "best thing that ever happened to China" despite my vain attempts to steer the conversation to safer ground. I could sense Father's discomfort as he munched a bit too loudly on his roast beef. But Larry was irrepressible. Father's a largely self-educated man, spending less than four years of his life in school. The apocalyptic bent of his new found faith often cuts me in the wrong places, still, I don't think he could have risen from the depths of depression were it not for the Chinatown evangelical group he joined eight months after Roger's death. I even think it has vastly improved his English, all that Bible study.

20 "I have a cousin who used to head the Physics Department in Beijing University," Father had said to interrupt Larry's enumeration of Madame Mao's theatrical achievements. "Oh? That's wonderful,” Larry, dense as always, had replied, stumbling into Father's snare. 
21 "I can't see why anyone would want to eat yogurt," I'd quipped even as Mother excused herself from the table. "You either have ice cream or you don't. "Why stuff yourself with tasteless muck," I'd muttered on. But Larry at once turned to me. "So, have you been in touch?" he'd asked Father.

22 "Not since they made him shovel manure in Mongolia to learn about revolution from the people," Father declared in his this-is-the-word-ofthe-Lord tone and Larry at once turned to me, having understood my sudden concern over yogurt.

23 "Please, this isn't necessary," I'd whispered to no one in particular. Then, Larry muttered his final undoing before Father: "Well, there were excesses, I must admit.”

24 “Excesses?" Father's tremolo could've belonged to the Sea Dragon King silencing the waves, the silverware leapt as he pounded the table. Larry couldn't have been more shocked if the Dragon King had in fact invaded our home.

25 "Let's say grace," I remember saying as Father looked away and Larry stared at his own hands.

26 I went home with Larry that night. I don't know why but it had suddenly seemed the only thing to do. Father had locked himself in his room after the dinner table incident. Mother strained to keep up conversation with us but the confusion and pain in her eyes were too much to bear. I heard myself saying in Chinese: "It's late, Mother, we'll have to be on our way." She looked at me and her eyes seemed to brighten for a moment before she quipped almost distractedly, "Yes...yes, you should be, it's late."

27 "How could I have done this?" I asked Larry in bed, "How could I have done this to them?" I said, fighting back tears. We both knew on the way to his place that we wouldn't be making love that night. I couldn't even bear to take off my clothes. It was terribly cold and I felt feverish. I hugged myself on the couch and Larry brewed coffee.

28 "I just killed them both, Larry," I said.

29 "Come on, Simone, they know the situation. We're getting married soon, anyway." 
30 “They've been waiting for someone to kill them off since Roger died and I just did it," I whispered in the dimness.

31 "You'll feel differently after we're married. We'll have kids and they'll have grandchildren to fuss over."

32 I looked at him and saw him smile and the space between us suddenly loomed awesome. "No, Larry, I can never give them grandchildren." Larry's voice was sad and confused. "What?"

33 “They lost everything with Roger's death. Can't you see? That's the only reason they're letting this happen. They don't care. They don't give a shit what I do anymore."

34 "I'm sorry," Larry said to protect us from silence. "I'm sorry about your dad. It was my fault."

35 "No. He meant for it to be that way."

36 "Those scars on his cheek," he said, "how did he get them?"

37 "I don't know."

38 "Looks like someone cut him with a knife a long time ago. Was he ever tortured... back in China?"

39 "I don't know," I said, my throat parched and my eyes stinging. "He's never told me much about himself. He's never really talked to me.” I swallowed hard to fend off nausea. And felt Larry's breath on my earlobes. "I love you, Simone. No matter what happens from now on."

40 I rested my head on his arm and probed his chest for those familiar callouses around the nipples. "How about these, Larry? You've never told me about them, either." I'd known that Larry was picked up by military agents shortly after he returned from China in '71 and spent the next four years in detention. I'd heard the worst horror stories about detention during my own brief and relatively uneventful incarceration, and suspected Maoists like Larry were known to have been tortured during the early years of Martial Law. But Larry has always avoided the subject. This is something he has in common with father. This black hole in both their pasts from which no light escapes and yet sucking in so much of the lives presently about them. I've never known Larry a Maoist. The TM-practicing health buff I met a year ago was anything but a political 
radical. He still maintains cordial ties with former colleagues on the left but cleaning up the environment and saving forests are his priorities these days. I think all that gab about the Cultural Revolution was cheap nostalgia or his misguided attempt to impress Father with his knowledge of contemporary Chinese politics.

"What else could they be?" he said in the dark.

42 "What?"

43 "Love bites."

44 It was the first time Larry made that joke. He'd said that of sundry wounds and scars. Yet, hearing the words still pricks my memories of some childhood sin. I'm reminded at once how little I know of Larry. Only twice have I met his son Frankie - who lives with his maternal grandmother - and neither occasion took over twenty minutes. I don't know if Larry has told Frankie much about anything. Larry's a sensitive lover but I could tell from the first that he hasn't had many. There's this old story that Larry's good friend Pol likes to tell about the heiress to a sizeable fortune that once offered to marry Larry on the eve of her betrothal to one of Manila's most eligible bachelors. "I'm a communist," Larry was supposed to have said. "I'm a marked man in this country. I can offer you no future." Next day, the woman runs off to Sweden with an Ermita folk singer and eventually ends up marrying a Sweden lawyer-or so the story goes.

45 I've never asked Larry about the heiress just as he has never inquired about my earlier loves. It's not indifference that has kept us from probing into each other's past but a sense of the fragility of our present relationship that can easily be overwhelmed by a surfeit of history.

46 "I like your dad," he whispered.

47 "Ya? So do I."

48 "You can't really forgive, you know," he said, though, I wasn't certain he was still addressing me, "I still have this dream some nights wherein I drag this poor bastard off the streets and cut him into tiny bits."

49 I'd never heard Larry like this and a chill ran down my back. 
50 "Yet, it's not a nightmare, you see, It's a pleasant dream. Quite pleasant. Maybe, he's had this dream too."

51 "Maybe you should talk to him again, sometime. Maybe he needs you to talk to him," I said, feeling sorry for the man beside me yet angry, inexplicably angry, though my voice remained calm. "Maybe he's been waiting for you to talk to him about us."

52 We were both silent for a while. Larry had dozed off but all at once it seemed to me that I've said everything I ever wanted to say to him. Then the phone rang. It was Mother making sure we'd made it home safely. It was the first time she'd called up Larry's place. It was the first time she'd looked for me anywhere in a long time.

53 Larry went back to sleep. In the dimness, the scars on his back seemed to glow purplish. For an instant they appeared to be exactly like father's. The same pockmarks defining similar welts as if there was this giant branding iron that all torturers in every age and place use on their victims. Some other nights I would have found myself kissing those scars. Softening the callouses with my fingers. But my fever had passed and it was time to leave.

54 It's nearly sunset and Father's still sitting by the phone waiting for the call from the Chinese embassy that everyone, including himself knows will never come. He's been reading his Bible for hours.

55 “Father," I whisper. "Let's talk, please," I say in Chinese.

56 He peers at me for an instant and goes back to his Bible and I want to grab the book from him and tear it into shreds. "The Book of Job," he says to no one in particular." That's the only thing anyone ever has to read. You figure it out and you'll have all the knowledge you need," he says in Chinese.

57 "Father, you can't leave," I say. "Father, I'm getting married. You have to give me away," I plead but he's not there. "For Chrissake," I blurt out in English.

58 "Don't blaspheme," he says, staring at me with those rock-hard eyes. And what I see is old, truly, and terribly old.

59 "I'm sorry. But why are you doing this?" 
60 He closes his eyes for a while and thinks of something to say. "My life is over. I must now live for the Lord."

61 What do you plan to do? Preach the Gospel in Tiananmen Square?” I could hear my voice thinning.

62 "China must convert. China must accept our Lord for the glory of our race," he says, his voice trembling.

63 I might as well be attending one of those Bible powwows the way Father's been carrying on but the anger is gone from me. "Father, please..."

64 "You don't need me anymore, Siao Mei," he says, calling me by my Chinese name, my girlhood name. I don't remember the last time he called me by that name. I don't recall the last time he called me anything. "You're a big girl now. You know what's right for you."

65 "You haven't invited any of your old friends to the wedding," I say.

66 "What for?" he says with a blankness in his eyes that cuts me in so many pieces.

67 A long time ago, before Roger was born, a fortune teller told Mother she could never bear children - she didn't have time lines on her palm.

68 "But I'm here," I protested. "I was born."

69 "You don't count," Mother had said. "Girls don't show up on palm lines."

70 I don't think I ever forgave Mother for that moment. I doubt she ever told Father the story. Still, I say to him. "You should have listened to the old people, Father. You should have given me away as an infant or drowned me in the river. It might have prevented Roger's early death."

71 Father hears me at last and he turns to me with a frightened, haunted look that I've never seen before. "I know what they say," I go on, "my karma's too strong. I can never have a brother. And I wouldn't have had one if not for mother's offerings to the deities."

72 Father's fear has turned to anger. "I will not hear that again, Siao Mei. I will not have any of the Devil's talk inside my house. The Lord has revealed to me his heart and I abide in him."

73 “I'm sorry," I say just to hear myself. “The huanna is a good man," he says. "Older men make better spouses. They are responsible and caring." 
74 I'm tempted to let the conversation end there but I know we've gone far enough this time. "No, Father," I say. "I lied. There isn't going to be any wedding. I'm not marrying Larry.”

75 "What?"

76 "I'm not marrying him, Father. There's really nothing between us."

77 He was confused and truly haunted now. "What are you saying?"

78 “There just isn't enough between us," I mutter, swallowing hard. Despite the years of silence between us and the fact that he has never raised a finger against me or Roger, I must muster courage to confront him like this.

79 "Not enough?" he asks. "You sleep with him," he says as if uttering a curse.

80 "It's not what I mean," I try to make sense knowing my words are stale and he no longer hears me.

81 "Why do you young people do this to yourselves? Why do you behave like animals? Why do you treat yourselves like dirt?"

82 "That's not how it is," I scream but the spirit has flown from me and my bones are weary. "That's not how it is," I mutter.

83 Father turns away and waves me off. "Go," he says, "just go and live your own life."

84 I think of doing just that but remember at once what I really came to say. “I loved Ah Di," I say, calling out Roger's Chinese pet name, his boyhood name - Piggy - for the first time in two years. "I bathed him as a boy. I defended him against bullies. I wrote for him his first love letter. He was my baby brother, Father. I would have died in his place if I could, damn it."

85 The back of his hand feels like lead. It is the first time he has hit me. I know it would be the last.

86 We part over white wine and Japanese food. Larry agrees that we should take time off from seeing each other and his six-month lecture tour at Tokyo University is quite timely. "I feel guilty pigging out while my mainland compatriots are risking their lives for the future of the race," I 
sigh over sushi. "It's enough you're with them in spirit," Larry quips and unloads a couple of jokes about Deng Xiao Ping.

87 It's easy to make light of events so far removed yet I'm really edgy about the latest developments. Chinese authorities have cut off satellite transmission from Beijing and the news blackout could be a prelude to violence. Larry thinks violence is inevitable. "There's no tradition of political restraint in the culture," he says. "It's always been winners take all. If push comes to shove, it could be bloody."

88 I shiver at the thought. I fear for the people in Beijing but I fear more for Father. I don't dare to imagine how he'd react if they started bashing heads in Tiananmen. He's quite convinced that the "crucial moment" for China has come. That the conversion of the Chinese people to Christianity is at hand - despite the absence of any sign of Christian persuasion among the demonstrators.

89 It's almost midnight and this guy having dinner with the German woman at the table beside ours is startled when voices emanate from his two-way radio. He's an old friend of Larry now editing a major daily. The guy says something over his radio and scrambles to his feet. "Sorry," he tells the woman. "I've got to go back to the office. We have to reformat. They're kicking ass in Beijing." The woman doesn't quite catch his drift and I hear Larry asking: "What's up, Mark?"

90 "The army has moved in. They've begun shooting," Mark says.

91 "Oh no," Larry says and I see his face folding in. Perhaps he wants to cry and I'm thinking maybe I can love this man, after all. "I'm sorry," he murmurs. "I'm sorry," and he lays his hand over mine.

92 "I've got to go, Larry," I manage to say. "It's late."

93 "Yes, it is," he says. "I really hope your Father will be all right."

94 I don't really know where I'm going. I wouldn't want to be the one to break the news to Father and in case he knows, which is likelier, I'd hate to be at the firing end of his misplaced anger. I cruise down the highway and suddenly feel that here are far too many cars on the road for the hour. I wonder whether it's the eve of some festival and am suddenly reminded of the nights at EDSA with Roger and his girlfriend, 
Anna. Linking arms with the multitude, facing down tanks, awaiting the downfall of a regime. I'd never seen Roger so animated. He's always been this apolitical whiz kid who was convinced that somewhere in all this mess would solve every human concern. Yet he was the most reckless among us. Running from one barricade to another. Haranguing the crowd, teaching anyone who would listen how to prepare Molotov cocktails. And when it was finally over, when they confirmed Marcos' departure, he hugged me and wept like a kid. Like the first time he was in a fight with this kindergarten bully. I'd never felt closer to Roger than that night at EDSA.

95 But that was over three years ago. Three long and unforgiving years. The advent of a new political dispensation has not brought forth peace and prosperity to our home, but death and silence. I couldn't weep for Roger back then. The short season of his sickness and death left me groping for meanings and scapegoats. But now I can sense the tears welling inside me. There is a sourness on my tongue and my lips are dry. I step on the gas and run a red light. Perhaps I'll drive all the way to Beijing. But before long I realize where I'm headed.

96 It's two in the morning and the guards are quite fidgety as I alight at the cemetery gate. They flash lights and appear genuinely disturbed. "Here's another one," one of them say. "What's going on?"

97 "Good morning, ma'am," the other one says. "What are you doing here at this hour?"

98 "I'm visiting my brother's grave. He's on Matahimik Street."

99 “The cemetery's open only from eight in the morning till six in the evening, ma'am. I'm sorry but we can't let you in."

100 "Please," I say. “Just this once, please. It's very important. It's family matter."

101 The shorter guard scratches his head. "Are you Chinese, ma'am?' he asks.

102 "Yes.'

103 “Are you going to do some kind of ritual?"

104 "Sort of," I quip, sensing their confusion.

105 "Is the old man a relative?" 
106 “Old man? Yes," I almost shout, "Yes, he's my father."

107 "He's been inside almost an hour," the taller guard says, looking quite weary.

108 "It's okay," I assure them. "This won't take too long. We have to do this tonight or his soul won't ever find peace."

109 The guards look at each other and open the gates reluctantly. All right, just this once," the shorter one says. "But don't do anything crazy. Our jobs are at stake."

110 “Don't worry," I say. “Thanks a lot. You're doing the dead a great favor. You'll be blessed for life."

111 Approaching Roger's grave, my headlights define the outline of a figure kneeling by my brother's tombstones. Father's never been here before, as far as I know. Chinese parents aren't supposed to light joss sticks or kneel before their children's tombstones. And Father's chosen to stay away altogether, although both his and Mother's tombs have been built beside Roger's.

112 I see smoke rising from the urn as I walk towards the tombs. The smell of incense arrests the thin air. I think I see Father looking over his shoulder as I approach. I've left the headlights on and I'm sure he sees me. I squat beside him and listen to him mumbling some ancient warrior's dirge. We're like that for a long while until I say: "You're not supposed to light joss sticks before sun up." But Father's deaf to me again.

113 Finally, I lean over and kiss him on the temple. "We can all go visit China, once this trouble is over," I say. "You, Mother, and I." His singing stops and I hear crickets taking up the slack. He is silent for a while and his head drops to his chest. The cold air nips me and I have to get up. I rest my hands on his shoulders. "I'm going ahead, Father," I whisper. "Don't take too long. It's cold."

114 As I approach the car, his voice rends the silence. "I'm sorry, Siao Mei. Forgive me," he says not looking at me. I drive away in the dark and turn on the radio and listen to an excitable British on the shortwave band says that scores have been killed as tanks crashed human barricades and all hell broke loose at Tiananmen, the Gate of Heavenly Peace. I turn 
the dial to catch Nat King Cole crooning: "Smile, though your heart is aching..." I park just outside the cemetery gates and turned off the headlights. I shut my mind and listen to Cole and forget for a brief moment the trouble in Beijing.

(Ong 55-69)

\section{Guide Questions:}

"Trouble in Beijing" depicts the conflict between a China-born father and a local-born daughter, Simone, who are trapped in their unresolved grief over Roger, Simone's younger brother. Roger's death proved to be the powder keg in the already volatile relationship of father and daughter. Partly due to the Chinese custom of barring parents from attending their children's burial, Roger's death remains a painful and unresolved reality in their lives.

1. Explain the rationale behind why "white hair cannot bury black hair" (par 4 ). What advantages and disadvantages can this practice bring to a grieving family?

2. In the story, Simone's father refused to sell goods from the mainland (but sold those from Taiwan and Hong Kong - free "Chinese territories") even as his competitors were raking in profits from selling mainland products. Can we dismiss this decision as simply poor business policy on his part? Why or why not? Trace the reasons for his decision and analyze them for their soundness.

3. Describe Simone's relationship with her father. To what extent is their relationship typical to that of a Chinese father and daughter? What beliefs do the Chinese have regarding daughters that account for such a relationship? 
4. Cite all possible reasons that led to further alienate the father and daughter from each other. Explain why her impending marriage is problematic.

5. Larry was an editor well-informed about China's affairs and yet he was hardly welcome as a prospective son-in-law. Why? Is his being huanna-a non-Chinese-the main reason for the objection? Would his welcome be different if he were an American?

6. The Chinese prefer that their children marry only fellow Chinese to continue their practice of ancestor-worship. Research on this unique practice to explain its importance in the Chinese way of life. Do you think this practice is still important today? Why or why not?

7. Part of the problem in the story is the conflict between the adherence to the traditional values and the western-influenced education of the younger ones. Larry and Simone's marriage became acceptable only after her mother realized that they were already sleeping together. Cite other potential problems the two would encounter if they eventually got married. Take into consideration how the Chinese view marriage and grandchildren.

8. Even today, girls have not quite reached the status of the boys in a Chinese family. Discuss why this remains so. Does the Filipino practice of naming a son a "Junior" the same as the Chinese preference for boys? Explain.

9. What is the role of a sister in the Chinese family? Does she occupy the same position as an ate in a Filipino family? How are they different or the same?

10. At the end of the story, Simone finds her father kneeling before Roger's tomb with joss sticks lit for her brother. According to Chinese custom, a parent should never light joss sticks and kneel before or even visit the grave of a child. Another custom forbids the lighting of joss sticks before sunrise and after sunset and yet Simone's father did all these. Why do you suppose he did so after staying away all those years? In the final analysis, what do you think is the author saying about traditions, death, and familial ties? Explain. 


\section{The Chinese-Filipino Woman as Wife or Concubine}

Since marriage among the Chinese is considered not just a union of a man and a woman but also a union between two families, it is the parents of the couple, with the help of a hired matchmaker, who traditionally arrange everything (Latourette 269). Filial piety demands nothing less than total obedience from the couple. Preparations for the expensive, elaborate rituals marked by exchange of gifts prior to betrothal and wedding rites are so tedious that to back out of an impending marriage is considered the height of ingratitude and inconsiderateness. This means losing face, which the Chinese regard as a fate worse than death.

In ancient times, a poor man usually paid a bride price for his wife, while the rich provided a dowry for their daughters. In any case, love was not a prerequisite for marriage but was considered a result of it. Although tradition dictates that wives obey their husbands, in reality, the Chinese wife has to please and obey her mother-in-law more than her husband. Unlike in the West where it is the men who crack jokes about their mothers-in-law, in China, it is the women who told these jokes. Although they are subordinated to men, women are more immediately subordinated to other older women due to their seclusion.

As earlier mentioned, when a woman marries, she ceases being part of her family and joins her husband's clan. Similar to her poor plight in her own home, she is expected to be obedient and observes filial piety toward her parents-in-law and most especially toward her mother-in-law. She is expected to following the latter's demands at all times and is treated as nothing more than her personal slave. This oppressive treatment of the daughter-in-law is born out of the older woman's jealousy of a younger rival for the affection of her son. Chinese mothers are unusually close to their sons because the birth of those sons accord them the respect of their in-laws, and pave the way for their improved status in the family. Generally, a wife only achieves her full power in the family after the death of her mother-in-law. To illustrate how formidable a Chinese mother-in-law is as a foe, one astute Han Dynasty mother counselled her daughter: "When you go to 
your husband's home, do not behave well for whatever you do will be wrong in any case" (Clayre 72).

In public, the relationship of a man and his wife is of indifference (Clayre 72). Whether or not there is love between the couple, calling each other names of endearment or engaging in any public display of affection is considered vulgar. It is the wife who has to work to earn her husband's respect and affection to secure her status in the family. Many marriages are unhappy but divorce is not really an option.

During the Tang and Sung Dynasties (618-906 AD and 960-1279 AD), divorce could be contracted through mutual consent. However, in later centuries, the husband could divorce his wife for any of the "seven reasons for divorce," which are disobedience, infertility, adultery, jealousy, disease, garrulousness, and theft (Clayre 74), while the wife was only protected by "the three reasons for not repudiating a wife," which are "she has no family to return to because her parents have passed away; she had observed a full, three-year mourning period for a parent-in-law; and her husband was poor when they married and is now rich" (Clayre 75). In reality, divorce is not really widely practiced. Aside from the disgrace it brings, a poor man cannot really afford to pay for a new bride, while the rich can simply take a concubine.

Usually, divorce is only considered if the wife is unable to produce sons. Contrary to the general impression, concubinage is not commonly practiced in ancient China. In reality, only the rich practiced it while the general masses were monogamous out of necessity (Gray 212). Compared to the wife, a concubine generally comes from a family of inferior standing. She is usually either hired like a superior servant or bought, considered a member of the family, at least while the husband lives, and helps the first wife in the running of the household. The first wife is called "Elder Sister" by the concubine and "Big Mother" by her children; (Clayre 76) she is treated as these children's true mother. Even the most favored concubine is not protected by the "Three Reasons" against divorce but she cannot be simply discarded without an arrangement with her family. Understandably, the coming of the concubine brings tension in the family but in some cases, because these were 
loveless matches right from the beginning, the wife welcomes the concubine and even treats her like a younger sister. This is not such a strange event owing to the unique structure of the family and social mores then; all things considered, the wife and the concubine are but one in sharing a plight of domination by the man.

The following short stories of Charlson Ong-“A Tropical Winter's Tale" and "Woman of Am-Kaw" - depict the struggles of Chinese women who come from tradition-dominated China to settle in the Philippines with their husbands. Noting the difference between Chinese and Filipino social conventions regarding women, we can understand Bei Xiong's seemingly inconsiderate, almost inhumane treatment of his wife Li Hua and Mei Gin's infuriating innocence and passivity. Torn between self- preservation and the dictates of tradition and society, the women triumph over many adversities. 


\section{"A Tropical Winter's Tale"}

by Charlson Ong

It was winter when he came for her. The last winter of her life. The cold air stung her face. Her throat was dry and her breasts were swollen. She felt her innards turn to stone and she was suddenly heavy with fear and longing. The man wore layers of animal fur-some strange animal the girl had never seen. They called him Bei Xiong-Northern Bear because he was said to have originated from Northern Province where it snowed in winter. The girl Li Hua had never seen snow.

2 She thought she must have another name, a real name but it didn't matter. His head was made of stone, his eyes were red, and when he turned to her in the half light, the girl thought for a moment that it was indeed some unknown animal standing before her. Her heart would have leapt were it not frozen.

3 The girl had been waiting for the stranger at the outhouse. The night earlier Bei Xiong had come with two sacks of rice, a goat and a jug of rice wine which he gave to the people Li Hua had always believed were her parents. They told her, however, that she was bought off some sick peasant as an act of Buddhist charity. But when she grew older the girl was too frail to work the fields, too clumsy to care for the young ones, had no talent for cooking or embroidery and could never be married off to a well-off family.

4 But Bei Xiong had seen the girl buying rice wine in town one day and decided to have her. He had two wives but neither had borne him any offspring. Now he wanted a younger woman. A fresh field to plow. And if she was yet a girl, he would be patient and wait for her to blossom. He needed a strong woman that he could take away with him to another land, across the seas where he would seek his new fortune after debt and pestilence had wiped out his crop and remaining kin. He would have a new life in that far away land of brown men who worshipped white gods; where many of his village mates had gone, where the earth 
was forever kind and the sun warm. He had enough of barrenness and winter.

5 Bei Xiong had asked for the girl and the old couple had consented though he was far from rich. The girl had no dowry and was worth far less than the food she consumed. The old woman gave Li Hua some of her own clothes, a bowl of steaming broth, some sweet potatoes, and told her to wait for her man at the outhouse. The old man berated Hua for being lazy and admonished her to thank the gods for not having dealt her a worst fate.

6 When the stranger spoke rocks grated against his throat but Li Hua knew he meant for her to follow him. He rode black mule and threw her a piece of fur to cover her face against the cold drizzle. Rain seeped through the girl's cotton clothes and her shoulders began to burn. For a moment, Li Hua felt an unearthly comfort and the fear flew from her body as ghosts of dead sparrows. She had always had an affinity with winter. The sadness without her was sister to the sadness within. But the fire raced down her spine and threatened to enter her. She screamed.

7 The woman awoke in a pool of sweat. In her dream, the snow fell the clumps as giant dumplings, burning her. She knew she was inside a dream but couldn't escape. She had to shake her head several times to fully awaken. The air conditioner was dead. Another brownout in the dry season. The woman thought at once of the good meat and foodstuff in the refrigerator.

8 Yesterday, some drunken customer complained that his meatballs tasted like clay, "These accursed brownouts will be the death of us," she cursed beneath her breath. Forty years of feeding habitués of their hole-in-thewall Chinatown eatery and her meatballs had always tasted like nothing else but meatballs.

9 She heard the measured pounding and the scent of dough being kneaded assailed her. It was six-thirty; the girls were preparing fresh dumplings for the day. Since the new girl was hired-Anna, yes that is her name she remembered, these "huanna" names continue to baffle her after forty years of calling them out-work seemed to progress faster. 
There were now six of them-three working in the kitchen and another three waiting on tables. The woman remembered how she fed far more customers working in tandem with their old cook Ah Beng-who had since left them-but that was many years ago.

10 The woman hurried down the stairs leading to the kitchen as she did every morning. "Good morning Mrs. Lao," the girls greeted her as always. "Good morning, Mrs. Lao," they repeated. It often sounded strange to her-especially when spoken by a "huanna" tongue-even after many decades of being so addressed. When she first heard Ah Beng greet her as he met them at the wharf-"Lao Tai Tai"-he seemed to be cursing. It took the woman a while to realize that was Bei Xiong's true name-Lao. Old Lao, most people called him. The woman had never called him. She never needed to.

11 For all his boorishness, Ah Beng was at least respectful of her. Though the differences between their ages left little doubt among the "lannang"people from the old country-that she was not Old Lao's first wife, Ah Beng continued to address her accordingly. Later, when the fact of her distant affinity with Lao was established, the thirtyish cook would refer to the woman as "sister-in-law." The rest of Chinatown would simply call her Li Hua, if at all. Only the "huanna" greeted her simply as "Mrs. Lao.”

12 The night he had her they had spoken a little. The man had hoped to be patient with the girl. He would wait for her to feel at ease, to come to him, but the coldness oppressed him, mocked his timidity, and turned his patience into desperation while she enjoyed her silence. She was centuries distant from him, wrapped in those wet cotton slacks reeking of drenched manure, trapped in her thoughts.

13 Her lips wanted to smile even as her eyes remained empty as a cadaver's and the man was suddenly frightened.

14 "Come here," he called her, trying not to be rude. "Make me warm." But the girl seemed deaf. Bei Xiong panicked. Had he indeed bargained for an idiot? Why else would the old couple have given her up for so little? She had sat almost unmoving in her corner since coming to his 
home two days ago, chewing occasionally on her piece of her sweet potato. Certainly his many layered brick home with its large heart which housed generations of kinsfolk before the plague was preferable to the old couple's mud shack. How can the girl be pining for such people who treated her not much better than an animal? She had not uttered a sound while trudging the ten "li's" to his village and since wallowed on her muteness-refusing food, unmoved by his gesture, dead to all else but some vision in her mind's eye. Bei Xiong felt his chest tighten, he had heard of "yao kways"-ghosts of those who died before forty, who possessed winter travelers. And Bei Xiong thought for a moment that he'd indeed taken in the very evil spirit that had cursed his family. The force of his backhand blow sent the girl sprawling and when she looked up, she saw him in the light for the first time.

15 Her innards seemed to be melting as she felt a sudden nausea. She was weightless now and the man lifted her and brought her to her fourpost bed-the largest bed she'd ever seen. He began undressing her brusquely. She wasn't sure what he wanted from her but a strange peace came over the girl. She was at once a child being rudely tucked in bed by an impatient father-the father she never had. She could hear him vaguely: “Don't you know how it's done? Don't you ever watch the dogs, the pigs? A rural runt like you?" she thought of the pigs and the dogs. She remembered the boar she helped their neighbor, Co Lay, butcher a fortnight ago. Li Hua loved butchering. The first time Co allowed her to try his big sharp knives, her hands and arms seemed possessed by the spirit of these wondrous metals. Li Hua could see in her mind's screen the brilliant blade sliding softly through the layers of flab and the deep red blood oozing forth then rushing out in torrents. She suddenly remembered how they had laid the bled pig down on its back even as Bei Xiong pinned her down. Bei Xiong tied the girl's arms and legs to the bed posts. She thought for a while he'd cut her open like they had the pig; carve out her entrails, her still throbbing heart and stew them in his aromatic herbs, said to be the finest in all Fujian. And then a hundred knives slashed through the girl's insides. But she thought only 
of the disemboweled pig. How she masterfully cut through the rib cage to extract the lungs whole and unmarked-perfect for cooking in ginger oil-how the entrails seemed to give in to her every move offering her no resistance. She had never been so much the master of her actions. And the girl knew then, in her heart, that is what her calling.

16 Li Hua told Bei Xiong about her talent for butchering. He glared at her in disgust and shook his stone head, convinced he'd bargained for a nitwit. She spoke to him again and the man flared up. Where on earth, he wanted to know, were there women butchers? Anyway, there was never enough food for people much less animals. After he'd disposed of his remaining property they would travel to Xiamen and board the ship to a place called Manila where Bei Xiong's distant cousin, who'd gone there earlier and apprenticed himself to a cook, would help Bei Xiong open an eatery. The brown natives of Lu Song were said to possess an insatiable appetite for Chinese food. Bei Xiong himself had worked in eateries in Fuzhou and Guandong where he learned from some of the best masters.

17 The wind soft and the sun gentle as they alighted from the boat. For two days and nights they were trapped amidst a sea of humanity aboard the overcrowded ship. Li Hua feared at times that she was among ghouls being brought to the land of the newly dead. But the air that greeted her was the scent of rice and palm. The man, Ah Beng, who met them was lean and square-shouldered. His teeth were the color of tobacco but his smile gave her strange comfort. When he called her "Lao Tai Tai," Li Hua thought for a moment that the man was addressing a fellow traveler invisible to her, but he smiled and she understood.

18 The "kalesa" took them through cobbled streets of gray stone houses and low wooden structures. She saw earth colored men and white women with hay colored hair. Even the "lannang" here laughed louder, their skins darker, like Ah Beng. Perhaps the earth was truly kinder here, perhaps she would bear Bei Xiong sons and he would treat her well. Her heart rose with the wind and she pined for winter. 
19 In the beginning, life was simple. She helped Ah Beng shop for fresh foodstuff at day break; they'd wash and prepare the meat, fish and vegetables while Ah Beng taught her the ways and words of the "huanna." Later, Bei Xiong would fry the radish cake and boil the peanut soup for workers who came for breakfast. The food was simple-dumplings, fried noodles, beef stew, "maki," "machang," "siopao," "siomai"... the people were simple. Li Hua made fast friends with other women from the old country. They brought her news of her home village. In the evenings she listened to the tilting melodies of the "huanna" over the radio which lulled her like the monotone chanting of Buddhist sutras or went to see a Fujian opera with friends. At night Bei Xiong came to her. Sometimes when business was good and he'd just had enough to drink, the man was gentle and the time passed quickly. He was always fast when gentle. Other times, when Bei Xiong had just turned over a day's earnings to the "huanna" policeman who dropped in occasionally for his favorite beef noodles, and had had too much to drink, he'd be rough and impatient. He'd wield his member like a weapon against a despised enemy. On such nights, Li Hua thought of the pig she had disemboweled, she remembered the grace and power her hands and fingers once commanded. Later, she'd try recalling other sights and sounds as his body mashed desperately against her. She'd try helping him but this made him angrier and more violent. She thought of winter, the sleet hanging from dead trees like mutant fruits. Her insides would freeze and the pain would fly from her body like the ghosts of dead sparrows. But in the end she always returned to the disemboweled pig, to the power and grace in her hands, and her spine would stiffen sending needles throughout her body as the man released his anger into her.

20 But when two years had passed and she still without child, Bei Xiong accused her of secretly aborting her pregnancies. Li Hua begged her innocence but his anger was beastly. He left her for dead and disappeared for weeks. Ah Beng nursed her wounds and ran the business singlehanded. At night he read poetry and tried to teach himself the words of the "huanna." He would practice calligraphy and sing to her 
songs from the old village. The masters, he said, would paint trees only in winter. For only in winter, stripped of foliage does a tree's true character surface. Yes, she answered, she understood. When he held her hand, guiding the brush along its smooth, plaintive arch, Li Hua felt the power return to her fingers. Not since the day of the butchering had her fingers been possessed by this unearthly force. The black ink spread cleanly across the crepe paper. Three strokes and their hands, together, had written the character for "person," he said. Then she saw his hands move up her arms, feeling her shoulders, her nape, her back and Li Hua knew then that everything that had gone before were but a means to prepare her for this moment.

21 One night as Ah Beng was teaching Li Hua calligraphy, Bei Xiong returned. His face was unshaven and wounded, and when he saw them he knew he was the stranger in their lives. Bei Xiong looked at the couple almost imploringly like cattle about to be slaughtered and went to his room. Li Hua fixed him supper. Early next morning Ah Beng was gone.

22 Ah Beng's departure left a void in their lives that would never be filled. Li Hua had to do the morning shopping by herself while she and Bei Xiong seemed to spend every moment of their lives cooking and waiting on tables. Some evening's Li Hua would try practicing the few characters Ah Beng had taught her. But without Ah Beng's strong guiding hand and vibrant eye that seemed to see beauty in a bowl of fried tofu as much as in Li Hua's crooked calligraphy, the spirit withdrew from Li Hua's fingers. And when Bei Xiong came to her at night, she could only think of the disemboweled pig.

23 During weekends Bei Xiong would be away on what he claimed was "business." The hours of his absence grew longer until he'd spend nights and days away from home. On such times Li Hua hired extra hands to help her with the work as words of Bei Xiong's almond-flavored dumplings spread among the "huanna" as well as the "lannang." Yet something close to joy seemed to have descended upon Bei Xiong. He was hostage to a distant anxiety and often seemed hard pressed to resist smiling just 
like the time he thought Li Hua pregnant. His new found lightness was a blessing to Li Hua and she was both glad and fearful but above all she savored his absences.

24 Bei Xiong brought the "huanna" woman home one morning. Her name was Clarita. She had black, silky hair that reached to her buttocks, her skin was light but the black in her eyes reminded Li Hua of brunt coal. She was smaller than Li Hua and not much older. Bei Xiong announced that Clarita would henceforth live with them. She would sleep in their room, eat at their table and help in their kitchen. The woman was with child, he said.

25 Something inside her told Li Hua she should be angry, that she should rage against Bei Xiong's animal ways. Yet, the thought of an extra hand to lighten her load, of another presence to liven up the deadening days of their togetherness gave her strange comfort. And if the "huanna" girl were truly pregnant, if she were indeed to bear Bei Xiong's child, then he may yet be saved from the anger gnawing away inside him. That night, Li Hua moved her own things out of their room and into the kitchen. She was now completely free of the man.

26 But before long Li Hua heard the ugly rumors spreading across their neighborhood. The "lannang" was distraught. Bei Xiong had always seemed an illiterate but honorable man. Even the "lannang" back home who took other wives housed them separately if within the same courtyard. How can Bei Xiong have two women, and one of them a "huanna" at that, under the same roof? "Shameless," they whispered. The man was truly descended from some northern barbarian. And many of the "lannang" stopped patronizing Bei Xiong's eatery. In the beginning they looked at Li Hua with pity but soon enough in disgust.

27 Clarita in fact grew big and Bei Xiong was never happier despite his diminishing profits. Li Hua too felt a sense of fulfillment. She was happy for the "huanna" girl and despite the ugly talk, Li Hua had never been more at peace. She helped Clarita bathe, brushing the long lustrous hair to life seeking expression and the sense of grace and power returned to Li Hua's hands, if only for a moment. 
28 Clarita and Li Hua taught each other their respective languages. They sang songs and shared stories. Clarita learned to cook and Li Hua to embroider. Li Hua began to feel that she at last had a family. And as the moments passed the shared conviction between the two women grew stronger that this was in fact their child to be born and that the man in their lives but an accident of fate.

29 But Clarita stopped growing, the time of her child's birthing came and nothing happened. Bei Xiong panicked. He took her to the herbalist who felt the woman's pulse and said she could not detect the child's heartbeat.

30 Must be a weak infant she consoled, and gave Clarita some medicine. Weeks passed and they took Clarita to the "huanna" doctor who pried into the woman and told everyone that Clarita had never been pregnant. A rare case she admitted but some women who desperately wanted to can in fact exhibit signs of pregnancy without being so. Bei Xiong flared up. He called the doctor a liar and had to be hauled away by the police. That night, the man's anger leapt from him as a wounded tiger. How could such things happen to him? Bargaining away his rice wine for an idiot girl and then picking up this "huanna" witch, this mad woman who can bloat her belly with nothing but air and lies. What evil had he committed in his past life to deserve such fate?

31 Li Hua could feel her own skin break as Bei Xiong beat Clarita. Her heart leapt as blood trickled from Clarita's lips. For a moment she wanted to rush to the girl's defense but at once feared for her own life, Bei Xiong had once nearly killed her. Bei Xiong dragged the girl out into the streets and threw her clothes at her. He told Li Hua to move back into their room and when he came for her she could only remember the blood, the knives and the pig.

II

32 The "huanna" girl excluded an air of unreality. Her eyes were opaque and unreadable. The old man often had to strain to feel her presence. But when he looked hard enough, her skin shone with a pained luster. 
He could tell from the way she carried herself that the girl was not born of a good woman. "She has bad bones." Bei Xiong said to Li Hua once. But he could see how the older woman had taken to the girl. "Anna," he could hear Li Hua calling out in the kitchen, "Your steamed chicken is getting better." Indeed the first time he saw the "huanna" girl, Bei Xiong felt hungry worn boring down his spine. Her round bloodshot eyes reminded him of another girl whose wolfish look had struck fear in his heart inside that outhouse ages ago. And he knew that some indescribable evil had once more entered his household.

33 Since the time he threw Clarita out of his house, Bei Xiong had little interest for women. He came to Li Hua less and less until finally deciding to partition their room. He had given up on anyone bearing him children and was revolted at the suggestion of adopting some "huanna" orphan. It had dawned on Bei Xiong that he was fated to live some solitary existence that he and Li Hua lived almost entirely separate lives bound incidentally by strangers who came for their food. It was but a matter of time before one of them dropped dead and their dilapidated building be torn down by some Taiwanese developer bent on remodeling Chinatown.

34 But the girl had brought with her a vitality that seemed to rub off even on their customers. People liked her and Li Hua doted on her...the old woman commented upon her every action - admiring her meatballs, criticizing her chicken soup - acting as though any of it truly mattered.

35 Li Hua was again retreating into her own world from which Bei Xiong had once saved her. The world she would share with Ah Beng, with Clarita, and now with this "huanna" wench, Anna. The woman was displaying once more the cold conceit that mocked him when she'd found common cause with Ah Beng and years later with Clarita, He could tell she was conspiring once again against him. Anna had finally turned her out. Bei Xiong saw the triumph on Li Hua's face as she consoled Anna and offered to take her in. The old woman's eyes were steeled as she stared down an incipient protest from a surprised Bei Xiong; they assailed him, mocked his aloneness and sterility. And when she spoke in 
that loathsome, gentle manner to the distraught girl, he heard the voice of a mother.

36 No, she had no right to be a mother, Bei Xiong raged mutely. She was barren like Clarita and all the women in his life who had failed to bear him progeny, to bear him the son who would be his joy and comfort in old age-the mirror of his own youth. A youth long lost and irredeemable. That land of the "huannas" had not been a land of rebirth and sustenance for him. Here was the same barrenness and death that had haunted him in the old country. He was the last of his line and his line was doomed. A proud and noble line of warriors, once honored by the Tang emperors, which would perish in this barbarian earth feeding grimy laborers and unlettered merchants.

37 In the beginning, fear had bound Bei Xiong and Li Hua. The alien night drove them into each other's arms. But soon their profits grew and became a wall of silver insulating them from the wiles and wherewithal of the "huanna." Policeman, revenue collectors, immigration people all dropped in regularly for their favorite meals and shares of their profit. Life was difficult but more bearable than in the old country and for sometime Bei Xiong imagined he would grow into an old wealthy patriarch of a large clan in this country. But the woman had given him no offspring. Had deceived him and poisoned those closest to him. She had seduced Ah Beng and made him - Bei Xiong, who had saved her - a cuckold. Yes, he could tell by their looks that night when he returned that the two had betrayed him.

38 He had been forgiving but her treachery was boundless. She would deceive Clarita - the only woman who could have borne him children and turn her against him. Bei Xiong was certain now that it was Li Hua, employing some despicable witchcraft from her village, who sucked out the spirit of his child from Clarita's womb. And now she'd taken in the "huanna" girl to drive him completely out of her life, to make him a stranger in his own home.

39 Bei Xiong marched downstairs to the kitchen where he could hear Anna puttering about preparing the day's foodstuff. She had been sleeping in 
the kitchen for nearly a month since weeping to Li Hua about being thrown out of the apartment she shared with foster cousins. Li Hua would still be away, it took her over an hour to haggle at the fresh food market. Bei Xiong knew he must act before the old woman returned. It was shameful but true that Li Hua's power had grown even as his own had weakened through the years. The demon, inside the woman whom he had fed and nurtured through the years was now a monster before which Bei Xiong often felt lost and confused. He could not look into the woman's eyes without seeing that demon staring him down. He could not remember the last time he won an argument with the woman or had his way with her. She ran every detail of their lives from the number of dumplings steamed for the day to the amount of small change he was allowed to buy cigarettes with. But she will not bring this "huanna" being into his home. She will not be a mother to this evil wench at his expense. When Li Hua returned Anna would be out of his home and his life forever.

40 The girl was unsteadied by the old man's voice. "You," he croaked. "Leave my house," he wanted to say, but the morning had lent vigor to her pout and he could see the outlines of her adolescent breasts poke haughtily at him through her "kamiseta." His belly ached.

41 "Come here," the old man finally quipped.

42 "What is it, Angkong?"

43 Her voice seared his ancient skin. "Don't call me that," he yelled. "I am not your 'lolo' I'll not have any "huanna" wench call me that."

44 "I'm sorry," she muttered, "but it's how Amah said I should call you."

45 The fire raced through his brain and he leapt at the girl as a scared prey. "Don't call her that. She is not your 'lola.' She is nothing to you and are you nothing to us. You have no business sleeping in my kitchen.” He gripped the girl's frail wrists as to his fading sanity.

46 Anna wanted to struggle, to hide from the rage seizing her, but she knew in a moment that the storm had trapped her inside its eye and all was futile.

47 "She told me I could stay." 
48 The girl's helplessness warmed his aching belly. Her eyes begged for mercy even as the blood trickled from her bitten lips. And in that instant the old man knew she was the one he had waited for.

49 "Do you want to stay?" he whispered.

50 "Yes."

51 "Be quiet then."

III

52 They were a strange couple, the girl thought. The woman must be sixty though her back was always straight even when eating and she never ceased moving around. The man looked much older to the girl and often seemed weary and disinterested. His presence was almost accidental and it was more than once when the girl mistook him for a customer as he hunched over a corner table sipping tea. "Don't mind him," the old woman would tell the help whenever he grunted and bellowed about how the food was deteriorating. "His brain is rotting," she'd quip.

53 Anna used to call the woman "Mrs. Lao" like the rest of the girls before she moved in with them and was told to call the couple Amah and Angkong. Amah was finicky about the dishes; a poorly washed plate could set off a long winded diatribe. Her Tagalog sounded funny at times but was mostly understandable. And she could be patient too, when teaching a new girl how to season roast duck or listening to another's latest plea for a loan. All the girls owed her at least half a year's wages.

54 When Anna told Mrs. Lao that she had been thrown out by her relatives, it didn't take the woman more than a few minutes to decide on letting her move in. She could not see though that the old man was disturbed. She could not see why. They were childless, after all, and she could not help with the house chores. Still, she made up her own mind to move out once she had saved enough to fend for her own.

55 The old man hardly ever spoke. What he uttered was mostly inexplicable and he seldom waited for a response. Sometimes he'd be gone for days and then lock himself up inside his room for a week upon returning. Whenever she brought him food, Anna would see him slumped on his 
hardback narra rocker with an empty look on his face. Once she thought he'd stopped breathing and nearly screamed, and then he groaned and his eyes were beastly. She froze.

56 Anna knew that the old man would soon turn her out. But she could not understand his anger when he came at her. She could not see how his frail, weary body could hide such rage. He was all over her in an instant, gripping her wrists so tightly she thought they would break. And then he was breathing down her neck uttering something into her ears. She could smell his nicotine breath as he began licking her forehead. She squirmed but he'd pinned her against the wall before darkness overcame her.

57 Bei Xiong slept like a child. Li Hua had never seen him sleeping so soundly and was almost envious of the peace that seemed to have come over him. When she returned home from the market with her load of vegetables, Li Hua had found Anna weeping inside the kitchen. Something steely ripped through her insides. Nausea clogged her throat and her heart clubbed against her chest. "What happened?" The woman managed to ask but the girl would only weep. "You must leave," the old woman quipped, swallowing hard. "But I have no place to go..."

58 "You must leave," she repeated.

59 Li Hua gave Anna some money and helped her to the door. "Goodbye, Amah...”

60 "Come back in a week's time," Li Hua whispered placing her golden necklace-her only piece of family heirloom-in the girl's hand.

61 It had been many years since she last held a cleaver, much less a butchering knife. Since her arthritic fingers began causing her pain, Li Hua had let the girls do the chopping and heavy kitchen work, content to supervise the cooking. Yet the twin knives felt surprisingly light. Bei Xiong's wrinkled skin offered no resistance as she slit the blades across his throat. The dark blood trickled and then broke out in waves. Lightness suffused her. She remembered the day of the disemboweled pig and the spirit of those wondrous blades returned to her hands. They knew exactly what to do - bleeding dry the carcass, splitting the upper 
torso and expertly removing the entrails and the organs. She had never been more the master of her actions and the fear flew from her as the ghosts of dead sparrows.

62 A few of the neighbors soon noticed Bei Xiong's absence and started asking about him. Li Hua told them he had gone home to visit his kin. But in truth, Bei Xiong had been disappearing slowly from their lives for many years and not long after, few would remember his real face. Once a "huanna" cop came by to ask some questions. He later learned, however, that the Manuel Santos, who allegedly owned the eatery, had died many years ago in Pampanga. Li Hua offered the cop some tea and almond cake and after failing to obtain useful information from the neighbors, he gladly went on his way. Anna returned to the eatery and stayed with Li Hua for many years until their side of Chinatown was razed by fire. To this day, many of the "lannang" say that for a few days after Bei Xiong's disappearance, Li Hua's dumplings exuded an exotic, addictive flavor, the likes of which they have not tasted before nor since.

(Ong 40-54)

\section{Guide Questions:}

1. Li Hua had no choice but to marry Bei Xiong since her foster parents had already arranged the marriage. Considering it was her life that was at stake, why was it so unthinkable for her to have objected to the match?

2. In the story, we see Li Hua transformed from a meek and obedient daughter and wife to become the powerful Mrs. Lao. Her influence and power grew that "she ran every detail of their lives, from the number of dumplings steamed for the day to the amount of small change he was allowed to buy cigarettes with" (par. 39). Trace the events that made this transformation possible. Could she have eventually become this powerful if she remained in China? Why or why not? 
3. Li Hua's only dowry consisted of her foster mother's old clothes, a bowl of steaming broth and some sweet potatoes. Yet she never complained nor thought of rebelling against her parents, Bei Xiong, or against tradition. Explain Li Hua's almost perfect obedience. To what extent is society responsible for her submissiveness?

4. Although Li Hua was exempted from mother-in-law problems, she was not spared humiliation when Bei Xiong brought Clarita home to live with them. Cite all possible reasons why and how Li Hua was able to accept such an arrangement. If you were Li Hua, would you consent to such an arrangement? Explain.

5. Since sons ensured the perpetuation of the clan and the practice of ancestor-worship, we can understand Bei Xiong's frustration at not having any son to bring him "joy and comfort in old age" (par. 36). Knowing how frustrated he is, is his treatment of Li Hua, Clarita, and Ana justified? Explain.

6. Initially, Bei Xiong's character is portrayed as some kind of demon"his head was made of stone, his eyes were red, and when he turned in the half-light the girl thought for a moment that it was indeed some unknown animal" (par. 2). Further action in the story did little to change how readers regard him. However, based on what you know about the Chinese culture and its regard for sons, can you say that Bei Xiong's untimely death was well-deserved? Explain.

7. Did the author reveal how he feels toward Bei Xiong and Li Hua? Based on the story, do you think Charlson Ong approved of the way a Chinese wife was treated? Why or why not? (If other stories of Ong have already been taken in class, support your answers by referring to his other stories.) 


\section{"Woman of Am-Kaw"}

by Charlson Ong

The first time she saw the wolves the girl Mei Gin dropped her bucket, spilling precious, deep well water she had drawn for two hours over the baker Old Ma's front porch, which was directly facing the moon before midnight wolves are born. She raced "without spirit" for home, awaking big Mother-Ah Lang, Father's first wife-piercing together a story of evil-smelling blue fog and gray wolves like giant rodents with fangs, the size of butcher Co Lay's slaughtering knives, between gasps of putrid breath. For her efforts Mei Gin suffered five pole lashes on her back, a sore earlobe, and a day without food.

2 Next day Grandma Lao, village herbalist, gave her "eight saints potion" to calm her nerves and "Fairy-wading across her stream" ointment to stem the tide of her fear whenever encountering strange verities of dark. In gratitude, Mei Gin fetched the old woman's water for three days and washed her hogs.

3 It was the season Ching Ming-clearness and brightness-when spirits returned from the netherworld, essences of all sorts abounded and filial sons journeyed home to their ancestral shrines to pay homage. The Wang widow, Siao Lan, whose husband died on their wedding night, was on her third and final year of mourning. Her weeping-singing went asunder the twilight calm, "O Master, thou are cruel. O Father, curse the day of my birth. Fate is a playful warlock. One day the fresh young bride, tomorrow, an empty-bowl widow."

4 The second time the creatures appeared Mei Gin calmly laid down her pails, sniffed from the pouch of magic ointment and chanted her sutra: "Goddess of Mercy, quell this evil before me."

5 They came at her but not for her. She saw them-three, perhaps more-a pack, chase each other past the well, rounding Old Man's store and scampering into the shrine of Ban Li Kung-deity of a thousand blessings, guardian of Am Kaw-the spirit of Sy Tek Su, ancient ditchmaker who had channeled the swelling river into the China Sea. 
6 The girl swallowed her heart which had crept up her throat, wiped a way of ointment across her nostrils and picked her way towards the shrine. Inside she saw a family in white mourning clothes-hands, knees, and forehead on the floor. Father, mother, boy, and girl. She watched them until her fear passed into fatigue. When she awoke, they were gone; their wolf tracks smeared by dung of chicken and dogs.

7 The early morning sun warmed her face-a gigantic bulb that some foreign sorcerer from the other side of the earth, in Gold Mountain, had lit across the heavens, Long ago the True Sun had burned out and the White Devils had flown steel eagles across the skies to hang their light above the seas. Tong Lai the village blacksmith, Am Kaw's first sojourner to the New World, had returned with pictures of the silver metal birds to prove his story.

8 Mei Gin chose not to tell Big Mother about the pack of wolves who turned into a family of mourners inside Ban Li Shrine just before dawn or she would have to go without food for the rest of the day.

9 The third time she saw the wolves outside the gate of Sian Kung Temple in the street of Binondo, in a village called Manila in the land of Lu Song, and she knew in her heart of hearts they had come for her.

10 When Northern Bear Yu, Am Kaw's wealthiest liquor trader, visited Lin Kay Siao's peasant home, Mei Gin was bathing baby brother Hao So, Ah Lang's youngest son. Through bamboo slats Mei Gin saw a large man in western clothes, like the ones the foreign priest wore on holidays. He had a clean-shaven pate, not unlike Hao So's infant butt. It was the first time she had seen a bald man. He was a Peiping man from up north who had snipped off his pigtail in defiance of the Manchu rulers. It was said that Northern Bear Yu had singlehandedly killed a hundred soldiers wielding his massive Sung Dynasty axe. The Ching Emperor feared the BEAR a thousandfold more than he feared the foreign devils. Northern Bear had his own army of northern warriors. Villagers avoided crossing his path whenever he rickshawed through the streets of Am Kaw. The town mayor, whenever forced to call upon him, would address the man as "GENERAL" or "BIG MAN YU." 
11 "I am a simple small town trader." Northern Bear thundered in his Peiping dialect. Lin Siao Kay felt the heavy hard-edged accent weighing down his shoulders. The monstrous laughter strapped his innards.

12 "To what accident of heaven does this inferior one owe such a distinguished visit...General?” Siao Kay strained to hear his own greeting.

13 Northern Bear slapped his thighs and waved away his escorts. "Brother Lin, I am a man of some means. My household is large and never hungry. I have four wives and sixteen children. My servants live better than most of you peasants. That is true. But for many years my women have been barren. I long for an infant son. It may possibly mean your good fortune, Lin.”

14 "Pardon the ignorance. But this useless peasant cannot ponder the great general's meaning."

15 Northern Bear's laughter sent the rats scampering and Lin felt insects crawling down his spine; his forehead was almost touching his own thighs.

16 "You southerners are full of crap! Don't worry. I will treat her well. My wives will treat her well. She will live like a princess. You are an honest man, Lin. You make honest rice wine. I like honest men, they make good daughters. Sixty yuan, ten foreign silver dollars, six sacks of rice, one water buffalo and one mule. What do you say, enough?”

17 A pained silence shot through Lin Siao Kay's ears. His groin ached; the insects were biting into his guts. Twice he had lost his voice. Once, a long time ago, when the landlord's men had come to take away his father for lying about his crop. And now this warlord comes to buy his daughter.

18 "I'm told you had her with a servant girl. Your wife hates this girl, doesn't she?" The sweet-stale stench of aged opium stung the old peasant's sun-baked face.

19 He gasped. "My daughter is truly useless. Big Man, she has not yet come of age. She is dull-witted and hard of hearing. Her skin is coarse as dried meat and cracks at the very touch of a strong man. Warts cover her body such as your brilliant eyes have not seen before. I'm truly ashamed." 
20 "Spare me your senseless self-mockery! You whining southerners have made a mess of this country. I'm no landlord; I do not take anything for free. I'm a trader. I offered you a fair enough price. Do you accept or not?"

21 "Please...please, General. It is not as easy as giving away a calf."

22 "You have enough daughters to beggar an emperor. How do you people say it? Having an infant daughter is worse than being attacked by a gang of bandits!"

23 Lin sat on his heels. If there was any dishonor a peasant upbringing spared him, his father once taught, it had to kowtow to anyone. "We break our backs to feed the emperor and his concubines. Never let your forehead drop below another's manhood," his father screamed at himstrapped to the oxcart, his head erect-the day they took him away.

24 Lin heard his father's voice assaulted his mind's ears. But he had also heard stories about Northern Bear Yu. About how the man-beast had once eaten alive an enemy. About how he had razed villages and violated fifty women in one night. And then Mei Gin, peering through the bamboo slats, saw the Spirit for the first time. A grey mist shrouded her father followed by the smell of wolves. A strange presence possessed Lin Siao Kay and knocked his forehead to the mud floor. Lin would struggle to his knees but the force would again prevail. Her father reminded Mei Gin of the funny toy of the foreign priest had once shown her. The priest had opened a multi-colored box releasing a clown that whipped back and forth ceaselessly. Northern Bear's massive scarred face wound into a scowl. Men had humbled themselves before the Bear but this was something else. The old man was mad. Lin was possessed by some playful spirit bent on embarrassing him-Northern Bear Yu, the great warrior of Peiping.

25 "Very well, very well! Stop this, old Lin! Don't break your old skull over some wench. Stop! In heaven's name I'm not asking for your head, you mad man! Alright, send her to my place in two days if you accept.” With that Northern Bear stormed out of the Lin's peasant abode in mortal 
fear of being ensnared by this malicious presence even as he ordered his escorts to leave behind a mule and three sacks of rice.

26 Lin Siao Kay did not raise his head from the ground until the blood on his forehead turned black. It was almost sundown when he finally moved. The spirit had withdrawn but no one had dared touch the old peasant. Ah Lang burned bundles of spirit money to appease the "Good Brothers"-souls of the unclaimed dead. She lighted joss sticks admonishing the souls of her parents-in-law to bring back the lost spirit of her husband. The entire village had gathered at Lin's home. Someone had asked for the town mayor, another called for the exorcist. But, in truth, none wanted to miss a single moment of Lin's possession. The dried blood formed a crayfish mound over Lin's forehead. He wobbled through his door as silence settled among his kin and neighbors. He wobbled aimlessly until he found the river. Lin buried his head into the running water and when he at last raised it, he wept. It was a bonepiercing cry as if all the unborn children of Am Kaw, the starved one hundred surnames in China had lent voice to his weeping. The villagers say it was the collective ghost of a thousand children weeping. But Mei Gin had heard it before; she knew it was the weeping of the wolf.

27 That night Father and Ah Lang argued. Father refused to send off Mei Gin to Northern Bear Yu. He'd rather starve to death than have his only daughter devoured by a northern beast.

“Then starve alone!" Ah Lang screamed. "Spare me and my children!"

29 "She's barely fourteen, woman!"

30 "You insult fate! Good fortune smiles upon you for once and you look away! What better deal can we get for that dumb girl?”

31 "What are you saying?"

32 "You'll have to give her away sooner or later. You don't have even enough dowries to marry her off to a beggar."

33 "Silence!"

34 The girl Mei Gin could not understand why Father refused for her go to Northern Bear's large house. She thought Father at least cared for herthe man had never beaten her. But now it was Ah Lang bent on doing 
her a favor. Mei Gin had once seen Yu's sprawling abode when her father sent her to deliver a jug of rice wine to town. The massive dragon gate reminded her of a mausoleum she had seen as a child when Father took her to pay homage to a distant deceased relation. She had heard people say that the Bear lived like the Emperor. Mei Gin had never seen a mandarin. None of her ancestral village of Am Kaw. But her mind's eye savored the blinding shimmer of golden palace walls, jade furnishing like living sea urchins. She dreamt of slipping inside the Bear's palace. She'd be happy to serve him. And now the man had come to ask for her, had spoken of making her a princess. How strange all these were. But stranger things had happened during this season of the dead.

35 Mei Gin felt her heart creeping up once more like the night of the wolves. But this time she urged her heart to beat faster and her spirit to wander. She would soon be living well. No more drawing pails of rockheavy water at dawn, washing babies and cleaning dung. Ah Lang would be but a bad memory. But why?! Why must Father refuse? Why must he keep her a slave for life?

36 That night Mei Gin dreamt again of wolves. When she awoke at dawn, blood smeared her thighs, her abdomen ached. Mei Gin wept in fear. The wolves had attacked her in her sleep. She would go to Ah Lang-the woman had cared for her, after all. But Ah Lang hated the sight of blood and didn't believe in wolves or dreams. She thought of seeing Grandma Lao, the old woman knew of such things. But the herbalist had been ill for weeks and was said to be dying-she might scare away Mei Gin's soul and take over her young body. Finally, the girl realized that only the alien magic of the foreign priest could quell this evil spell.

37 "Not wolves," the large, foreign priest with the eyes of the color of sky and hair like corn stalks, caressed Mei Gin. "Not wolves, dear child. God is telling you that you are now a woman."

38 A woman like Ah Lang. Like her own mother, Siu Kim, Beautiful Lute. Ah Lang's maid whom Father had taken to wife-she had died of a strange sleeping sickness. Will I be Father's wife, too? Will I die in my sleep? 
"No, no, Mei Gin. You will be a beautiful woman. You will have a good husband and bear him good, strong children."

40 Will he put me up in a big house like a princess? Mei Gin told the foreign priest about the Northern Bear Yu. The priest made Mei Gin promise to stay in the chapel until her father came to fetch her. When Lin Siao Kay came, the foreign priest, who spoke all the languages of the world, asked him why he had sold his daughter to a man like Bear.

41 Lin found his voice-"She is my daughter and I can do anything I want with her!"

42 "She belongs to God!" The foreign priest kept the girl inside his white stone chapel.

43 “Whose God?!" Lin Siao Kay's anger pounced like a wounded cat at the white man's growing indignation. "Your Western God owns nothing of mine!" Lin insisted on taking Mei Gin home but the foreign priest had warned Mei Gin she'd go to hell if she ever went with Northern Bear $\mathrm{Yu}-\mathrm{a}$ devil he was, cast out from the Lord's kingdom.

44 "Let me have my daughter, foreigner!"

45 "Only if she wishes it."

46 The girl wept at the sight of her father, at the sight of his anger which all at once seemed puny beside the white priest's sudden stature. The white man was at least two-persons tall. Mei Gin remembered her father kowtowing before Northern Bear; she feared for him. The girl knew her duty, but she feared the terrors of Hell even more. She was afraid of the man-like beast with a bull's head and a goat's tail.

47 That night Lin Siao Kay and Northern Bear Yu came to the foreign chapel with torches and many of the Bear's wild warriors. They shouted for the priest to release all the young village girls he had lured to be his mistresses. They set afire effigies of white men and threatened to burn down the chapel. That was when the priest sent his old helper, Ah Bien, to fetch Mei Gin whom he had earlier delivered to a foreign house in Foochow. Ah Bien handed Mei Gin the foreign money given by the priest and took her to the wharves. 
48 When they reached the boat Ah Bien told Mei Gin that the foreign chapel had been razed and the white priest hanged by Northern Bear Yu. He gave the girl two notes, one for the "huanna" captain on board and another for Ah Bien's relatives in a place called Manila where the boat was headed. Mei Gin had never sailed on a boat; she had never ridden on anything but an ox cart.

49 The "huanna" captain wept when he heard the foreign priest's death. He knelt on deck and made the sign of the cross-to the Father, Son and Holy Ghost. Three Gods in One, the priest had once explained to Mei Gin-foreign gods were strange. The captain made Mei Gin do likewise. He called her a "sister in Christ." He had learned to speak Fukienese from the white priest who long ago had cast out an evil spirit from him - the ghost, they say, of many of those who have drowned. Mei Gin had wanted to be baptized by the priest but Father refused.

50 "Do not mourn, young sister. Fr. Le Sage is now with Him." The "huanna" captain consoled Mei Gin.

51 "He died for me!" the girl cried. "It is my fault and now I've lost everything. What is to become of me now?"

52 "The ways of the Lord are often difficult to know. He has plans for you." The "huanna's" words reminded Mei Gin of the white priest.

53 “Are you a priest?"

54 "No." He spat out his denial as if some incantation against a lingering curse. A pain crossed the "huanna's" bearded face. He turned away. "Once, long ago. I thought it was to be my calling. But I was wrong." He walked towards the railings and would have leapt into the sea had not a wicked wind blown away the ghostly sadness that reminded Mei Gin of the first corpse she had ever seen.

55 That night Mei Gin heard once more the wailing of wolves. She could hear it dying as she drifted farther and farther away. But when she awoke she saw it was her father. Lin Siao Kay, raising his bloodied head from the river weeping for his lost daughter, for all the lost daughters of Am Kaw. She saw the stone chapel wrapped in flames and her innards scorched. A dozen torches burned inside her and Mei Gin rushed for the 
railings but the "huanna" captain was waiting. His arms cold and wet as the first snow of winter tamed the fire within the girl. He chewed at her ears-"No! Not yet. You are too young."

56 "I am cursed! I must go back. My place is within him! I have betrayed my own father. I am unfilial! Worse than a dog!"

57 But she had grown weak in his arms. The coldness sweeping through her. Touching her in ways she had long forgotten. Once she must have been so caressed, by her mother, perhaps, or in another lifetime. Mei Gin saw her spirit flowing away. "She was as young as you are." Those were the last words she heard before the sea and the pain.

58 The "huanna" town fascinated and horrified Mei Gin. She saw many white men; their hair like sun-burnt hay and the eyes of a color she had never seen. This must be the land of foreign priests. Here the White God of Love and Mercy reigned supreme. To this land had journeyed many of her own village mates. A few had returned with wealth yet unknown in Am Kaw. Some came home saddened and silent. The old people say these once had lost their spirits to the "huanna" witches whom they've taken to wife. The sad ones would often forget their homes and relatives. They wandered about aimlessly or sat alone in mud corners until the wife or kin sold their "alien papers" to others who were bent on journeying to Lu Song. The old people warned against buying these papers-to assume the identity of people who'd lost their spirits made one susceptible to a similar fate.

59 Mei Gin had suspected that her villagemates left Am Kaw not so much in search of wealth but in want of a greater god. The Yellow Emperor whose divine corpse was the land of the Middle Kingdom and whose body hair had fathered their own fathers was powerless amidst steel eagles, gigantic bulbs and Western priests. Riding in a horse-drawn "kalesa," through the cobbled streets of Manila with its grey stone and wooden buildings like endless rows of foreign chapels, watching the brown, earth-colored faces staring back at her, Mei Gin wandered how 
many of them were actually her own people from Fujian who'd shed skins and memories.

60 The "huanna" captain took Mei Gin to a place called Binondo. She had no papers; it was safer for her to be among her own people. She would feel at home. The Chinese of Lu Song had different ways. They called themselves "lannang"-our people-and although the language they spoke remained recognizable to Mei Gin, it lacked the melodious quality familiar to her. The language had lost its spirit and the "lannang" spoke it among themselves merely to still the incipient fear lurking it among themselves merely to still the incipient fear lurking amidst them. Many of the "lannang" had ancestral altars and placed To Ti Kung-the god of the earth-inside their homes and stores. But others wore the clothes of the "huanna' and spoke in tongues the girl had never heard before. The people of exile always had enough, if not too much, to eat. They celebrated many feasts. Some were feasts from the old country but they also observed the feast days of "huanna" saints and gods. It was as if all were making up for the many years of famine. Perhaps a surfeit of feasting would exorcise forever memories of want and starvation.

61 Although Binondo had one of the grandest Buddhist temples Mei Gin had ever seen, many of the "lannang" went to the foreign church. Those who were baptized removed the ancestral portraits from their altars and placed instead a crucifix or a picture of the White God. They threw away their incense and joss sticks and refused to partake of food offerings to the elders. These were ghost food, they claim, tasted by demons. Mei Gin could not understand why people took away portraits of their ancestors. What would happen to them should they pass away in this land? Who would lead them back home? How were they to be reborn? Many nights she would sweep over her misfortune. She who had forever lost parents and kin. There were nights when the "huanna" sailor was away. Few of the "lannang" ever spoke to Mei Gin. When she asked about the ways of the "huanna," old woman Ah Sim would grunt and growl, mumbling some inaudible sounds that the girl thought were the 
woman's village dialect. "Do you come from Fukien?” Mei Gin would ask. But Ah Sim's dagger looks sooner or later disturbed the girl.

62 "Why did you bring me to this place of the deaf and dumb?" Mei Gin asked the "huanna" sailor.

63 "They are Chinese. They are your own people. If you can't get along with them, how can you get along with anyone else in this country?"

64 "I get along with you." The girl almost smiled and the sailor thought he saw another child-woman hidden behind Mei Gin's charmed sadness. The girl he had found in an orphanage had brought home and loved. For her he turned his back on the priesthood with only a few months left before ordination. He married her but the Lord would have his way, she died in childbirth too young to be a mother.

65 "You speak better Fukienese that I've heard any of them speak," Mei Gin quipped. "I'm not sure they speak anything at all." The girl was embarrassed by her own brashness. In the few months of their togetherness they had barely spoken to each other. Whenever the "huanna" sailor came home from his travels at sea he would bring her small gifts of exotic perfumes, Japanese pearls, once, even preserves from China. When he was to go away he would hand Mei Gin some money and a note-just in case any immigration inspector showed up. Every morning the Cantonese butcher Bai Lee brought her fresh meat and vegetables, leaving them outside her door as the sailor had instructed. Once Mei Gin had waited by the door and opened it just in time for Bai Lee. The bull of a man was startled at the sight of her as if some monstrosity and fled in mortal fear.

66 "I don't know why they fear me," Mei Gin wept.

67 "You're new here, give them time."

68 Mei Gin busied herself with cooking and making a home for the sailor. But the "huanna" would not even touch her before retiring to his room silently. He was the only person left in her life and Mei Gin longed for him. She longed for the strength and the coldness that had stolen her from the sea that night. For the pain that was more than a pain. But 
he could only beg her forgiveness and speak of another one in another lifetime.

69 "They're getting even younger." Rabit Pai, the Taiwanese grocer quipped as Mei Gin walked down the main cobbled street. It was the first time she had ventured out into the streets alone. Whispers dogged her. "Where does he pick them up ... the 'huanna' ghost." "Some wench from Taiwan or Macau." "Poor girl, shouldn't be a day over sixteen." "It's in the bones, bad bones."

70 Bad bones. A long time ago Ah Lang had screamed that the girl had "bad bones." Just like her mother! She'll end up in some dirty house in Shanghai, whoring for foreign devils." When bad women from the big cities came to town, Mei Gin would get up close trying to feel their bones. The good women would glimpse the outsiders from the side of their eyes but none dared to sneer too loudly or show disdain. They remembered the time when a jilted village toughie called Northern Bear's favorite woman, Yellow Orchid, barren sow. The Bear's men cut off the young man's tongue right before the town elders. Ah Sim's glances reminded Mei Gin of the women of Am Kaw.

71 "Why do you look at me so?" Mei Gin finally confronted Ah Sim one morning as the old woman was shooing away children.

72 "The 'huanna' sailor's woman!" A fat boy yelled, scampering away. "I saw her! I saw the woman!"

73 "Mother will beat you up!" A girl retorted, chasing after him.

74 Ah Sim turned away. "Please Old Aunt, why do they say these things of me?”

75 "What kind of young woman shacks up with a 'huanna' sailor?"

76 "He saved my life."

77 "It's bad enough some of our men are lured by these native wenches. But you have to come here and live with a 'huanna.' You shame your family! You shame your village! You shame us all! Who are your parents? Do they know where you are?"

78 A sharp dryness stung at the back of Mei Gin's eyes. She was cold. "I have no family." 
79 Ah Sim's indignation melted into a confused gentleness. "Are you an orphan?"

80 Mei Gin wept though she had sworn not to. "I am not a bad woman."

81 "Leave the 'huanna.' You're young, there are many of our men here who will still have you."

82 "He is good to me."

83 "Fool! He is a sailor. He has women wherever he goes. You are not the first girl he has brought here and you won't be the last."

84 That night the "huanna" sailor gave Mei Gin some papers.

85 "These are your papers. You are now MARIA MORENO. Maria-the mother of God."

86 Maria. Mei Gin heard herself utter her new name like some mythical incantation. The Mother of God. Maria. She loved her name. He made her hold a pen and carved her fingers bled as she worked on perfecting the letters. She was infused with vigor. She wielded her pen as she would a divining rod. She was now beyond the stares and poisoned tongues of the "lannang," beyond pain and memories, beyond the past.

87 "This is your name, now. Remember. Forget all else, this is you." The sailor gave her a bundle of "huanna" money and taught her some of the words. He told her she had been through a bad dream and must now awaken unto a new life.

88 "Yes, we shall have a new life together."

89 Lightness suffused Mei Gin. God's plan for her came in an pungent wave of fresh sampaguitas and human breath.

90 "You must be with your own people."

91 "I want to be with you."

92 They were together that night. By daybreak the sailor had gone. Ah Sim spoke to the girl: "The "huanna" is gone. He's asked us to take you in. You can move with us if you want.”

93 "Gone? Where? He will be back. He always comes back. I'll wait."

94 "Listen. I won't say this again. The "huanna" has gone away and will never return. He still has a heart, he's set you free. You have until tonight to move in with us." 
95 Many days and nights passed but Mei Gin's door remained closed. Not a sound was heard from her room. The neighbors were one in their muted fear. For months they had suffered this indignity amidst them in pained silence. They feared the "huanna." Although he was mild-mannered and rumored to have once been a "man of God," the sailor wore a strange air about him. They whispered among themselves about the many young girls he brought home. "He devours young flesh to stay young..." "It's the juices..." Yet the half-breed Carlos confided to Ah Sim that the "huanna" merely took care of these girls in retribution for a wrong he had once committed.

96 "Nonsense!" the woman barked. "He’s a beast."

97 The next door neighbors had taken to putting talismans on their doors. They would never forgive the "huanna" for devouring one of their own under their very noses. He had been at most a curiosity. Suspect but at a safe enough distance from their lives. Bringing home a Chinese girl was the worst insult against the "lannang." They cursed in their shared disdain. How low have sunk the women of the Middle Kingdom. They came to these barbaric islands willing to take on any physical labor, suffer all inconveniences but not to have their dignity sullied. And the girl had destroyed it all; through her they were stained forever.

98 Yet they were careful not to speak too loudly of the "huanna" sailor's woman or to face east when they cursed lest the east wind carry their voices too far. One should never offend a "huanna" much less a strange one like the sailor. He could easily make life difficult for them. How many of the "lannang" owned alien papers? How many bore "huanna" names but could hardly utter a syllable of the foreign tongue? An inspector could flush out half the illegal residents and carry away their hardearned fortune. Let her be. She would soon regain her wits. And now the unspeakable was at once a presence. What could have happened? She must be the curse sent by the abandoned women of Amoy. Her death could spell the undoing of them all.

99 On the seventh day Ah Sim, bearing a talisman and the remainder of her pride knocked gently on Mei Gin's door. The old woman froze as she 
heard the howl. Ah Sim quickly struck herself to regain her senses and rushed back home.

100 "What is the matter, woman?" Her husband Yu Bien had never seen Ah Sim so disturbed. Ah Sim cast a quick glance and fidgeted.

101 "What is it?" Yu Bien asked. But the woman had lost her voice and kept herself busy to avoid her husband's inquiries.

102 At midnight a knock startled Ah Sim from half slumber. The door knob felt like burning lead. Ah Sim could smell essences from the "other world" standing at the other side of the door. The sailor's woman stared at her in the dark; Ah Sim saw hundreds of eyes staring at her as she muffled a scream. The child-woman entered upon Bien's household like a regent. She sat herself upon Yu's high chair, back straight and legs apart.

103 “Are you hungry?” Ah Sim heard her own voice tremble.

104 The girl ate like a hungry wolf, consuming the household's weekly provisions.

105 "Must have starved for days...” Ah Sim whispered to Yu Bien.

106 "Why did you take her in?” Yu fumed. Ah Sim fell silent.

107 For days the girl kept to herself. She sat by the window watching blankly the traffic of commerce and humanity, without uttering a sound.

108 "Now, what do we do with her?" Yu Bien asked his distraught wife. "Do something!" he screamed. "I'm afraid..."

109 After a month Ah Sim summed up enough courage and talked to the girl; "Lim, the butcher, is a good man. He is a widower; his wife back in the mainland has died. He has been alone for many years. It will be a waste of such a good man as he should take on a 'huanna' woman. He asks about you..."

110 A week later, Ah Sim had arranged for Lim and Mei Gin to be wed. In the midst of the celebration Mei Gin leapt atop the wedding table and her placid countenance wound into a scowl of disdain. She stomped her feet and waved her arms as an ancient warrior-"Lim, I condemn you! For fifteen years you left me alone to care for your parents without 
sending home a single dime. I suffered and died a broken woman and now you have the gall to remarry."

111 A deathly silence came over the gathering. Lim fell prostrate. The crowd was stunned. The spirit of Lim's dead wife had taken over his new bride. She spoke with the voice of the aggrieved dead. It was said that a powerful wind lifted Lim off the floor and flew him out the window.

112 Mei Gin's fame spread among the "lannang." She could summon the spirit of any dead relative from the mainland. She would tell supplicants the plight of their kin and friends back home. "No rose is forever red," she answered the man asking about his fiancé whom he had left behind for five years. Those with intimate queries would beg to see her in private. She would suddenly castigate cynics, exposing their darkest secrets, leaving them shamed and dumbfounded. People stopped calling her the "huanna" sailor's woman in fear of incurring her wrath. Yet there was almost nothing anyone knew about her. A traveler once mentioned that the girl resembled a lost daughter of a certain Lao of Am Kaw. She was believed to have gone mad because of ill-treatment from Lao's wife. The girl had begun seeing ghost wolves. She was lured by an evil foreign priest and taken away. The "lannang" of Binondo did not care to believe such tales, they kept faith only with what the girl spoke during her trances. They would speak of her as the woman of Am Kaw.

113 The woman of Am Kaw was sometimes called the "Empress" by the "lannang." She took on gestures of the Imperial Mother whenever the spirit possessed her. Her devotees multiplied and Yu Bien decided to convert part of his home into a temple-Sian Kung, the "Empress" named it-where the Woman of Am Kaw could minister to the "lannang." Although she did not accept payment for her spiritual services, people brought food and gifts as homage to the Spirit and the household of Yu Bien grew prosperous. Very soon the "lannang" had forgotten that she was the strange girl the "huanna" sailor had devoured in their midst. People of exile have short memories. The old people insisted that she was the angel of vengeance sent by the abandoned women of Amoy to 
castigate their menfolk while those who worshipped the Western God called her a demon.

114 It was many seasons later, the "lannang" recall, when a large bearded man with deep scars carved unto his face and neck arrived in Binondo. He entered the temple of Sian Kung one day and came up to the woman of Am Kaw who was then in a trance. The crowd fell into a tense silence. The woman awakened as if seeing some otherworldly creature. She stared at the man for a long while before standing up and ordering her devotees to leave.

115 That was the last anyone would see of the woman and the stranger for several months. The "lannang" were distraught, The Woman of Am Kaw was a vessel of virtue. A filial daughter. Hers was a bodhisattva's body that will never know men. The stranger who was perhaps from some unheard of island, must have been sent to defile the woman. The old people say he was dispatched by "huanna" witches to destroy the power of the Woman of Am Kaw and silence the voices from home.

116 On the eve of the Ching Ming, no longer observed by many of the "lannang" of Lu Song-they had since adopted the day of the dead of the "huanna"-Chinatown burned with news. Maria had at last been seen with the "huanna" entering the Sta. Cruz Church. They were seen kneeling before the foreign priest. Maria's head was wrapped in a black veil, her spirit had indeed been captured by the stranger.

117 Next day, Maria finally spoke to her devotees.

118 "For many years you have called me Maria. Yet you know her not. Maria is the mother of the one true God. The son of man-our Lord Jesus Christ. Today, I am truly a daughter of God. Brothers and sisters, I have found my true fate, my real devotion-Christ! If you really believe me, then listen. Forgive me for the deceptions of many years. I have allowed unnatural presences to use me in keeping you in darkness. Now let me atone by showing you the way. Allow yourselves to be baptized, we shall 
be siblings in Christ. Those who partake of the Body of Christ will never die and shall be with the Father on Judgement Day."

119 The "lannang" heard the voice of evil speaking through the woman. It was then that the memory of the forsaken girl and evil "huanna" sailor passed among them as a foul wind. Yes! Here again was the beast who had devoured one of their own in their very midst. Now he had returned to take away the Woman of Am Kaw who had lent voice to both living and dead from home.

120 Maria revealed the entirety of her past to her devotees. She would devote the rest of her life with the "huanna" to caring for young women led astray by sellers of sin. Not long after, many young girls came to live with Maria. Some were "huanna," others were "lannang" from Macau and Hong Kong. Some had been sent from Amoy to be concubines of those who had come upon great wealth in Lu Song. Maria taught them the ways and language of the "huanna." She brought them to church to be sprinkled with water by the white priest. At night they chanted guttural verses and sang foreign hymns. In the mornings they strung rosaries of oyster shells and coconut husks while the "lannang" watched in despair. Maria had brought bad women in their midst. She and the "huanna" were up to some evil. The girls will be sent out to sow discord and death among the "lannang" whom the white priest had called "heathen" and low. Yet they feared the "huanna," but mostly, they feared Maria.

IV

The girl, Estella, was a Portuguese half-breed from Macau. She had escaped from the textile merchant to home. She was sold by the Cantonese ship captain who won her in a mahjong game. The oldest among the "lannang" remember her as the "number one brush under heaven"-Chinatown's "foremost calligrapher" in her time, they say. She'd clamp a brush between the outer lips of her vagina and paint birds and bamboos on scrolls auctioned off for fortunes by the merchant to drunken revelers. 
122 The night she came to Maria's home the merchant had sent men chasing after her. But they were all repelled by Maria who stormed out of her home with a man-sized crucifix while screaming foreign curses. She startled faces in fear of being burned Estella lived with Maria and the other girls for many months before bringing about their doom.

123 It was a young half-breed, a boy, not yet sixteen the son of a jeweler named Tan-who was smitten by Estella's sad charm. He tried wooing Estella with trinkets from China and pearls from Sulu. But the girl, weary of the lures of men and much loved by "her sister in Christ" rejected the boy. Some believe this made the boy go mad while others insist it was Estella who demanded him to do the dastardly act in exchange for her love. Whatever the reason, the boy in a frenzy stormed into the textile merchant's store one morning. He stabbed to death the older man and carved out the merchant's heart. The boy was seen running with the bloody organ still writhing like a decapitated snake-towards Maria's place. When he reached the door, the boy prostrated himself and begged Estella to love him before he dies.

124 At midnight, Tan, the jeweler led a throng of torch bearers to Maria's home. They called upon Maria to release the boy from her curse and for all the women to leave town or else be burned alive. They had suffered enough of this indignity. Some insist that it was then that Maria turned into a she-wolf attacking the crowd, while others claim a powerful wind blew the torch flames towards Maria's home setting fire to the place. Then, the old people say, a large pack of wolves broke through the gates, scampering every which way, entering homes, attacking sleepers and chasing away the spirit of restless dreamers. The fire spread, engulfing many of the "lannang's" homes and stores including Tan's own house.

125 One of the wolves entered the home of an artisan whose wife, back in China, had just died of typhoid. In his deep sadness he thought the spirit of his dead wife had come to bid farewell but when he felt the supple skin and silken hair he knew she'd possessed the body of another and would be his forever. Now, this artisan had recently been baptized because the foreign priest could not allow sacred images of the Church to be soiled 
by pagan hands, and the priest had named him Tomas Resurrecion. Tomas and his wife had six children, the last of whom became my father.

126 So, Fr. Molina, you must know my grandmother was a she-wolf and the evil blood flows through my veins. Five years of theology, ascetism, prayer, sacrifice and service to my fellow men have done little to quell the incipient longing of the flesh. I must admit to a pinch of desire whenever the laundry woman Maria enters my room to collect the laundry. Oh! Why couldn't she bear any other name? MARIA. The sound rushes through my bones as a wave of fire. Her bosom weighs heavy upon my manhood. But truly, Fr. Molina, her suspicions are unfounded. I believe with all my soul that in time, under your thoughtful spiritual guidance and the sustenance offered by my brother seminarians I shall earn the privilege for which I am ready to lay down my life at any moment.

127 And if I have chosen, without your knowledge, to keep a weapon by my bedside it is only because many among my grandmother's pack of wolves still roam the earth tracking down descendants such as I. You see, they are beyond salvation, beyond the fear of God. Crucifixes repel them not. But if you so mandate, I obediently surrender this weapon to your care and leave my destiny in God's hands.

(Ong 1-20)

\section{Guide Questions:}

1. In the story, one can see the "manners"-the customs and traditionsthat the Chinese follow. Part of this elaborate custom is the very Asian trait of self-mockery, the belittling of oneself or of one's station in life. (This includes mockery of his looks, his children's intellect, and others.) This "humility" is especially demanded when one is relating to someone whose stature in life is above yours. Mei Gin's father greets Northern Bear Yu with: "To what accident of Heaven does this inferior one owe such a distinguished visit..., General?" (par. 12) Even a Northerner like the General starts his proposal by saying, "I am a simple small town 
trader" (par. 11) when he in fact was Am Kaw's wealthiest liquor trader. Discuss how adherence to this practice can sow discord between the more traditional parents/grandparents and their modern, western-influenced children/grandchildren.

2. The conflict in the story started due to Northern Bear Yu's proposal of "marriage." Note his offer of 60 yuan, 10 foreign silver dollars, 6 sacks of rice, one water buffalo, and one mule for Mei Gin. This offer is considered generous especially when we recall the wife in "Tropical Winter's Tale" who was given away for almost nothing. Can we say that Mei Gin's father erred in not consenting to the proposal? Why or why not?

3. There's an old saying referring to the practice of giving expensive dowries that says having infant daughters is worse than being attacked by a gang of bandits. What does this saying reveal about the Chinese regard for sons and daughters?

4. Why do you suppose the practice of dowry-giving remains today? In what ways are daughters still looked upon as commodities to be traded and/or sold?

5. Initially, readers may consider the conflict between the foreign priest and Lin Siao Kay as a simple misunderstanding that ended tragically. However, if we study the history of the relations between the Chinese and the foreign missionary and the relation of a father and his children, we would understand that this conflict involves more than just religious differences. Explain why the conflict of Lin Siao Kay and the foreign priest in the context of the story ended the way it did. How is this conflict between Lin Siao Kay and the foreign priest similar to the history of China and the foreign powers in the 19th and 20th centuries?

6. Mei Gin was a fruit of the relation between Siu Kim, a slave, and Lin Siao Kay; and yet she calls Ah Lang, her father's wife "Big Mother." Explain why this is so in light of the family system in old China with its practice of concubinage.

7. The Ching Ming is the Chinese equivalent of All Souls' Day. Celebrated in spring, this important festival is devoted to visiting one's ancestors in their tombs to offer food, light joss sticks, and burn spirit money. 
Lighting these sticks made from sandal, garoo, and other fragrant woods mixed with cedar or fir is indispensable in the proper observance of rituals. The Chinese believe that the smoke of the joss sticks would reach the netherworld together with their prayer for their dead. Two sticks are lit for the dead while three are for the deities. Moreover, spirit money (made from coarse paper with gold or silver denominations and bought from Chinese shops) is also burnt for the use of the dead in the afterlife. The Ching Ming is an important occasion as it allows the clan to gather together to pay proper respect to its ancestors.

Influenced by Confucian ways, traditional Chinese still believe that they do not belong to themselves but were only part of a line from their ancestors to their descendants. This is in sharp contrast to the staunch individualism that the West advocates. Explain how a strict adherence to this custom can create conflict between the older generation and their modern, western-influenced children and grandchildren.

8. When Mei Gin is brought to Manila, she cries out: "I am cursed! I must go back! My place is within him! I have betrayed my own father! I am unfilial! Worse than a dog!” (par. 56) What is filial piety to the Chinese? Is it the same as obedience?

9. The Chinese are said to be one of the most superstitious people in the world. Based on what you know or have observed about the Chinese, is this true? If you think this to be true, cite some beliefs they adhere to.

10. In Chinese symbolism, the wolf is the emblem of cupidity and avarice. What is the Western belief about wolves and werewolves? How do these beliefs about the wolf relate to the story of Mei Gin? 


\section{The Chinese-Fillipino Woman as Matriarch}

Unlike Westerners who dread the coming of old age, Chinese women look forward to this stage in their lives. During this stage, they achieve greater stature in the family. Traditionally, a Chinese matriarch has complete say in the running of the household and controls and vastly influences the upbringing of her children, including grandchildren and other relatives in her home (Clayre 71). She is so revered a figure that children are taught to immediately obey her summons, follow her dictates, and support her decisions. Although technically, she is supposed to obey her son, filial piety has exalted her position in the family to the point that her son usually gives in to her wishes at all times. Her life is happiest at this point and she finally gains the respect of men, young, and old alike.

It is this absolute power of the Chinese matriarch that helps us make sense out of how a grown man like A Puy in "How My Cousin Manuel Brought Home a Wife" can be reduced to a wreck when dealing with the numerous demands of his mother and aunt. Usually threatened with emotional blackmail, sons are left with no recourse but to give in to their mothers. For the Chinese matriarch, customs, and beliefs regarding ancestral worship, choice of mate, death, and other important issues are of paramount importance that veering away from them would surely ignite war. This we witness in Benito Lim's “The Burial.” The following short stories show the dilemmas of the Chinese-Filipino families torn between tradition and change and the important role their matriarchs play. 


\section{"The Burial" \\ by Benito Lim}

Benito O. Lim was born on March 14, 1937. He graduated from the University of the Philippines with a degree in English Literature in 1957 and earned his Master of Arts degree in Communications from the University of Pennsylvania. He was a former editor of the prestigious Literary Apprentice and an associate professor in Chinese Studies and Communications at U.P.

After a while I could look without squinting. The first thing I saw in the house was the coffin laid on two bronze brackets. Incense burned in jars at either side. The coffin was carved with dragons. Their black eye glared against the red of their scales, and their yellow tongues and legs strained to attack the naked bulbs strung around the white walls of the room.

2 The mourners seated at the end of the room were silent. They were sweating profusely in their white clothes. They had unbuttoned their shirts. They fidgeted in their seats without taking their eyes off the coffin. Once in a while they would flap their shirt fronts to make a breeze. At their left side was a round yellow table on top of which a gilded porcelain Buddha was surrounded by bowls of steaming rice. Trays of shrimps, crabs, and meatballs exuded a warm unctuousness which mingled with the sour smell of sweat. The door at the mourners' right which led to Grandfather's room stood open. At the dark corner near the door, a woman's figure in white great effort. I could hardly distinguish her but I knew it was Mother.

3 I went across the room, past the sweating mourners who gaped at me as I entered my Grandfather's bedroom. I stood motionless for a moment inside the dark room. Then I asked her to close the door.

4 The room was cool and unusually spacious. After a while my eyes were adjusted to the darkness. Most of the furniture had been taken away. Grandfather's bed was still on the left side of the window facing the door, the rocking chair on which my ancestral history was carved stood 
right in front of the bed. Behind the bed were the richly-carved table and three chairs which formed a set together with the rocking chair. On the table was one of Grandfather's treasured porcelain, a tea kettle with dragons on relief. The kettle had been broken, patched together, and preserved all the time. I caught myself smiling at Mother's hysteria when my cousin-in-law Juana broke the tea kettle. For days against Grandfather Wang's chidings, Mother labored with tar and glue to restore the kettle only to get it more and more askew.

5 It was one afternoon while Grandfather was asleep. Juana and I entered his room looking for something to play with. Juana asked me to get the tea kettle for her. She thought it would be fun to have it as a toy. I refused to give it to her, deepening my voice; I explained anything with dragons was sacred. Juana was angered by my refusal. When I finally let her take a look at the dragons, she snatched the kettle from me and smashed it on the floor.

6 I opened the window and switched on the light. The blue paint of the room had faded into gray and there were cracks along the entire length of the walls. The small table, the three chairs and the bed looked barren after Grandfather's things were removed and hidden.

$7 \quad$ Mother's red swollen eyes were smarting under the glare of the light. She had grown very old. She was a bare skeleton in her mourning clothes.

8 Mother asked me to turn it off. I turned it off, she asked me to sit. I sat on one of the chairs near the window and faced her.

9 "When did you arrive?" her voice was very faint. "A while ago," I answered, through the darkness. "Did you take the six o'clock train?"

10 "Yes." It was a curt reply. I could sense that Mother expected me to say more.

11 "Who met you at the station?" Mother asked unmoving in her chair.

12 Clearing my throat, I replied: “Uncle Luciano and Cousin Juana.” I could swear Mother winced at the way I addressed our Filipino relatives.

13 “Did Luciano say anything about me?” I felt Mother's eyes glaring at me. I pretended not to hear. I tried not to talk about the incident at the river after my arrival. 
14 It was about six o'clock and the train wound along the last curve leading to town. The lights in the station alternated: red to mauve, green to red. The train coughed off its mass of black smoke when it halted with a jerk. It was dusk, the passengers were rushing to get off the train. The luckier ones who got off sooner crowded on the platform. I inched my way to the narrow train corridor, and was above the noises of the crowd. I heard someone calling, "Hsin! Hsin!” It sounded familiar.

15 "Hsin! Hsin!" It was the same voice, this time it was louder, "We're here, "Hsin!" I turned and looked across the heads through the window of the train. It was Juana's father, Luciano. Although he was not a blood relative, he being the son of grandfather's Wang's wife by her first marriage, I have preferred to call him Uncle.

16 “Wait, Uncle!" I shouted. When I hurried out of the train and finally out onto the platform.

17 "Hsin!" Uncle Luciano seemed unable to contain himself. "Hsin, you've come." He said grasping my hands. "We've been waiting for you for so long.” Behind Uncle Luciano stood a woman. I stared at her. I wasn't sure when my uncle let go of my hands.

18 “Oh, I almost forgot," he said and pushed Juana forward. "Here is your cousin Juana.”

19 "How are you, Hsin," she said shyly. She lifted her eyes then turned it down quickly. She was as tall as I was.

20 “Ana,” I was surprised to hear myself calling her by her nickname. "Ana," I called her once more. She was no longer the scanty little child I knew when grandfather Wang was still alive. Ana had grown fuller, lovelier. Her breasts and hips filled out her once gaunt figure. “Ana, Ana,” I kept calling her.

21 "Did Luciano say anything about me?" mother asked again.

22 "I'm not sure, Mama," I hesitated. "What should Uncle Luciano tell me about you? Why can't he tell you himself?” I wished Mother would stop asking.

23 I thought of the ease with which the horse drew our "caretela" through the cemented street. The sun's rays diffused in dull reds, made all the 
forms blend into shadows. I sat beside Juana. She was very still, almost stiff and her eyes were turned away from me, towards the distance. The wind blew her hair back revealing the delicate shape of her neck. She was blossoming.

24 "Ana," I whispered.

25 She did not turn, as if she were lost in the rhythmic rattle of the caretela.

26 "Ana," I called her again. But my voice was drowned in the sound of wheels and the horses trot.

27 She must be deep in her thoughts of Grandfather Wang.

28 "We missed you, Hsin," Luciano turned to me from where her sat on the cochero's seat in front "your grandfather too, I believe. Oh, I don't know really."

29 "I missed you all," I said aloud, hoping Ana would turn her head to me.

30 We drove until we reached the asphalt road; then we turned toward Franco extension. Immediately before us rose the steeple of the San Agustin Church. The lamps were already lighted. The streets were deserted.

31 As we approached the church I recognized the sounds coming from the church. People were reciting the liturgy for the dead.

32 "They are praying for your grandfather. It is our offering for his soul." Uncle Luciano explained.

33 The church was well-lighted. People filled the pews from end to end. The air smelled of melted candles.

34 I looked at Ana. I caught her looking at me out of the corner of her eye. She quickly looked away. Blood rushed to my head.

35 "Your Mother said he died yesterday morning," Uncle Luciano continued.

36 "Mama said the same thing in her telegram," I affirmed.

37 The asphalt road turned left and it changed into loose gravel sloping down into the fields of Baloan. Wide fields lay darkly before us, ending in the black clumps of trees. Farther up, the river sang. The wind was cold. I felt Ana shiver behind me. Uncle Luciano urged the horse on guiding it carefully on the bumpy road. There were big stones and ruts all over the street. The wheels of the caretela groaned as they headed 
up and rolled down. Ana held on to the crossbars of the caretela. She breathed deeply, yielding herself to the jerky motions of the vehicle.

38 Soon we were in the middle of the fields. The smell of the decaying plants, upturned soil and carabao dung enveloped us. Then the sound of the river grew louder. At times the river slashed angrily at the banks. Uncle Luciano turned to the river bank and stopped the caretela.

39 "Let's rest for a while," he said and stopped down the caretela. "Besides..." he faltered, then went on, "I must talk to you before you see your mother."

40 “What about?” I asked as I alighted from the caretela.

41 "Oh, Hsin, I don't know how to say it. It has been going on for some time, I mean, the way your mother treated us. It's six years since you went to the university. Since then things have changed. Your grandfather's cough grew worse, he suffered a lot. Then your mother took him into your household. He was not allowed to leave the place. Oh, Hsin, your Lola suffered so much after that. She was allowed to visit him, but what the woman could bear visiting her own husband in another household? You should have seen how your Lola cried... it pains me, Hsin... for two long years it has been that way. And...” his voice broke and he cried.

42 "Come Uncle," I said, "I think it is wrong to offer flowers to the dead, I mean, it is against the Chinese custom."

43 "Can't you do something? It means so much to Mother, those wreaths, it's the only time she could honor your grandfather," Luciano insisted as he try to control himself.

44 "It is not our custom to offer flowers," I repeated.

45 "So, it is against your Chinese custom!" Ana cried from the caretela, "It is not our custom to offer food and burn incense to the dead. But do we prevent your mother from offering food? Don't we let her burn incense as much as she likes?” She came down the caretela and came close to me. I turned away helplessly.

46 "You mean you can't even try to persuade your mother? Don't you understand?” Uncle Luciano pleaded. 

understand, Hsin."

51 Ana was silent. She was breathing heavily.

52 "Luciano said something about me, didn't he?" It was Mother again, this time she spoke sharply.

53 "Yes," I weighed my words. "Uncle Luciano said something but not exactly about you. It was something about flowers Lola sent for Grandfather...”

54 "You mean Luciano's mother!" She interrupted.

55 She turned away and for a long time she could not stop herself from sobbing. Her hands gripped the armrests of the rocking chair. In the darkness she mumbled: "Many things happened since you left, Hsin. Your grandfather was not very sick when you left. Then he visited your Lola more often and slept there every night. It was like that for four years. His cough grew worse and worse. When one day he collapsed here, in this very room, I knew he was a ruined man. From then on, I took care of him until yesterday morning. As if...as if they had not done enough harm, Luciano brought flowers. Flowers on top of your grandfather's coffin to damn Father and us!" Mother was hoarse.

56 "But Mother, flowers mean just the opposite for Lola. She is honoring Grandfather," I explained.

57 "No, my son, you no longer understand!" Mother groaned.

58 "Grandfather himself would've been honored," I continued, "he always wanted us to live the way Lola and Luciano live."

59 Mother was sobbing violently. Through the window the stars were tiny silvery spots on the dark velvet sky. The night was placid and the tall fields of grass were mirror blades reflecting the stars. There was an indifferent silence in the night while Mother cried. 
60 I tried to forget Mother. I laid my head on the window ledge that smelled of moss and mushrooms.

61 In those days, when the city was being built, we had to reach it from Binmaley Highway, over the Calmay River and across the fields. The streets swerved one after the other - the newly risen factories lined themselves with the swerving streets. The circular plan of the city could be seen from the steeple of the San Agustin church. The steeple was the hub of the city. One could see far around. There was the Chinese cemetery directly opposite the Filipino cemetery, then behind the two cemeteries, a short distance away were clumps of the nipa shanties with their rusty aluminium roof tops made from advertising signs. There was the river of Calmay bordering the city, flowing from east to south, cutting across the Baloan rice fields as it left the city and together, the river and the fields stretched as far as the eyes could see. At sunset, a golden sheen rippled the surface of Calmay. Its water flowed indifferently through the two cemeteries. From behind the church where the processions of roads from the neighboring towns. The widest of these roads originated from the railroad station.

62 When grandfather was alive, he used to take a walk with his friends, lawyers, doctors and laborers. I, too, had taken walks with him, longer ones. He told me stories about my ancestors who left China and wandered about in the outside world, and returned successful. Grandfather explained their wandering as the fulfilment of the tradition of dragons. Stories of my successful ancestors were always told with so much passion. Sometimes his insistence on success in business made me feel he was afraid. Sometimes Grandfather would say mysteriously: "This is the end of our wanderings."

63 The days when Ana and I played in Grandfather's room, he would sit up from his sick bed and watch us play while he smoked a cigar through. He would often call us to him and stroking his head gently he said: "You will soon realize that you are different, but I hope you shall be one." Without knowing why, I felt Ana and I belong to each other. 
64 The muffled cries of the mourners were drowned by the sudden clatter of basins, silver, and plates from the kitchen downstairs. The people were busy preparing for the wake.

65 "Hsin," Mother called, her tone almost tender. "I had to throw some of those flowers away. You understand, don't you?"

66 "Yes," I said.

67 "Yes, I know you understand," Mother said, somewhat comforted. "No, they can't damn us, not while you and I are alive." She laughed hysterically.

68 I thought of leaving the room but the mourners had started crying again. The mosquitoes buzzing around me and the lamentations from the other room sent my head whirling.

69 I laid my head on the window sill. It felt cool. Mother had begun to rock her chair. The whole room swayed with her. I opened my eyes hoping to steady myself. Then the sky was whirling, bending, and stretching continuously. I tried to raise my hand to drive the bussing away but my hands had grown numb.

70 Gradually the moon came out from the clouds. Mother was asleep. There was no longer any crying. The whole house was still. After great effort I was able to stand up. I walked straight to Grandfather. No one was keeping vigil. The electric lights were out. All the windows were open. In the moon-illuminated room, I moved closer to the coffin. I could not see grandfather's face. The moon was reflected on the glass. Mother's hollow voice was metallic: "They cannot kill us while you and I are still alive." I peered through the glass, straining to see through the reflection of the moon on the glass. I couldn't see grandfather's face. Moving closer, directly above the glass, my head cast a shadow on the moon. In the limpid light I saw the same old Grandfather now unstirring and clean. His eyes were half-open; they caught my gaze and led my eyes to a rose between his hands. My eyes began to smart after peering through the glass for some time. My knees trembled. I tried to stay on my legs by leaning heavily on the coffin. Slowly, my knees weakened until I knelt 
before the coffin and I was face to face with the dragons. They were old and gray in the moonlight and charged with fierceness.

71 "Hsin! Hsin! Are you awake?"

72 "Hsin!" someone whispered into my ears again.

73 It was Ana.

74 "I have something from Lola, Hsin."

75 I shook my head vigorously shaking off my drowsiness.

76 "Please come with me, Hsin."

77 We left Mother silently. The lights blazed outside where the mourners were still keeping vigil. For a while, i kept blinking my eyes. People were still seated in a circle. Sighs and cries momentarily punctuated the liturgy going on at the table on which the Buddha stood surrounded by cold food. One drowsy head would suddenly droop then it would jerk violently up, as if startled. The dragons on the coffin glared and their red scales dazzled.

78 I followed Ana downstairs. The plink of silver and china came louder.

79 The kitchen which led directly to the garden, was built like a cellar. The women were setting the table in the middle of the kitchen. At the right end of the room was the altar with the wooden image of Buddha brightly lighted with candles and incense sticks. A man was kneeling in front of Buddha. He kept bowing after each recitation of his prayer. There was another altar at the left end of the room, where the image of the Virgin Mary was also brightly lit by candles. The candle lights cast limpid shadows in the kitchen. Ana stopped at the kitchen door.

80 "I suppose when he's through," nodding toward the man before the Buddha, "you'll follow," she said.

81 When I did not answer she turned to the altar at the other end of the kitchen and knelt before the Virgin. I followed her.

82 The two women did not seem to mind us and the man before the Buddha continued his prayers, oblivious to everything about him.

83 The cold wind from the garden made the candle flames flicker. I moved nearer Ana. Her eyes were fixed up to the altar. She was beautiful as she knelt beside me. Her bosom rose and fell regularly with her breathing. 
I felt my blood throbbing against my temples as I watched her. After a while, she made the sign of the cross and stood up hastily.

84 I stood up with her and follow her out of the kitchen in the garden under the moonlight. At the gate where the kerosene torch burned she showed me a wreath and bouquet of roses.

85 “These are from Lola. It is her farewell to Grandfather Wang.” Ana said. "You'll put these on Grandfather's coffin, won't you Hsin? If only for Lola's sake."

86 "I've talked with Mother but she refused to put any flowers on the coffin," I explained.

87 "You mean you did not explain to her?" Ana's voice sounded harsh.

88 "I tried, I tried to explain but she refuses to understand. Ana, please believe me, I do not want to...” Ana refused to listen any further. Angrily she started to run away from me, I held her quickly by wrists and pulled her closer to me. We stood face to face. For a long time we gazed at each other.

89 "It's useless to talk with you!" she snapped at me. Her eyes caught the moonlight, they darted nettles at me.

90 “Ana, I'm sorry. It's Ma, please don't be angry," I pleaded. She struggled and pulled herself free.

91 "You don't care for Lola, or for anyone of us! You hate us!" her accusations tore at my vital organs.

92 "I do care," I protested, "I care for Lola and for Uncle... and I love you, Ana.”

93 Ana turned her head away sighed heavily.

94 “Ana, I love you," I said again.

95 Then she looked at me straight into the eyes, "Then why did you not accept our wreaths?” she was challenging me.

96 "Please understand Ana, it's Mother who refuses to accept..."

97 She did not listen but ran directly out of the garden, into the open fields towards the river.

98 “Ana, wait!” I called her back. I pursued her. Through the faint light I had only Ana's face to guide me. I kept shouting “Ana!” until it seemed 
that the whole countryside echoed her name. She was running faster unmindful of the mounds of caked earth against which my toes were constantly jabbing. I caught her at the river bank. I held her tightly, pressing her to me. She struggled and almost fell.

99 "Hsin! Let me go!" she was gasping, "you are hurting me!"

100 "Ana, I love you, Ana, I love you” and heard myself repeating. I held her tightly until I could not feel our bodies throb together and feel her yielding to me. I kissed her over and over again on the mouth.

101 "You are one of us, Hsin, you are one of us," Ana murmured and kissed me back.

102 For a long time, we clung to each other in silence.

103 Inside the house I had to readjust my eyes to the glaring light. Mother was alone, keeping vigil. She knelt before the coffin, burning incense papers. Her eyes were fixed on the dragons. She seemed to be conversing with them. When she heard me enter, she quickly threw the gilded strip of paper into the incense jar.

104 “Where have you been?" she asked.

105 "I took a walk to the river with Ana," I answered trying to appear casual.

106 She did not speak. When she spoke again, she told me to get some rest.

107 I was dozing off to sleep when suddenly a scream burst through the other room. She kicked and stamped the flowers which had fallen on the floor, I seized her by the shoulder and shook her gently.

108 “Stop it, Ma! This won't do you anything good." I tried to calm her by making her sit down.

109 "They are demeaning us... the two of us!" she leaned on me crying wretchedly. I didn't know that to say and only clasp her closer to calm her.

110 The brilliant sunlight made the coffin glitter. The trees swayed with the wind. In the garden behind house, men were decorating four trucks with strips of white cloths on which were Chinese inscriptions and anagrams intended for the world of the dead. These was a truckload of Chinese musicians. They were turning their instruments, the din they made hammered into my head. I spotted uncle Luciano from the crowd. 
I couldn't find Ana anywhere. My heart beating wildly beneath my ribs. I turned away from the window and sought grandfather's room.

111 In the daylight, the room did look as bare as it did the night before. The ornate and massive pieces of furniture crowded against each other. The rocking chair, battered and bruised as it was, had most of the reliefs worn off. I found Mother looking out of the window, watching the preparations for the burial.

112 "You told Ana, didn't you?" mother kept her face turned away from me.

113 I did not answer.

114 The funeral will soon start. "Tell Luciano and Juana not to insist their flowers this time!" Then as if to herself, "Why can't these people let me bury my father in peace?"

115 A shrill melody came from outside. Someone was playing the "siao." The melody was nasal, it came out slow and hesitant, ending abruptly as if it could not sustain itself. It made me more aware of the damp, moldy air inside the room.

116 After a pause, the Filipino band played Gounod's Ave Maria. The music began slowly and quietly, almost reluctant. As it grew louder and louder, it became more dense, gathering more momentum, heaving and swelling into agony.

117 "Hsin!" it was Ana. "Let's go!" she tapped me gently on my shoulder. "The funeral will start soon."

118 I trembled to feel her hand on me. Last night's vigil had been for Ana's coming.

119 "Let us go," she said again as she walked ahead of me, out of the room. "You are to lead the group which will follow the hearse on foot."

120 Mother was waiting for me at the foot of the stairs. She eyed Ana but said nothing. Ana stared back at nothing. The two women measured each other in cruel silence.

121 "Please, Ma, the funeral will soon start," I interrupted, sensing a quarrel. Mother looked startled as she turned to me.

122 I guided Mother, brought her to the waiting hearse. Ana had disappeared into the crowd. Mother was sobbing. I knew it was more out of 
anger than sadness. I grasped her arm and pushed my way through the crowd. I wanted her to bid grandfather's goodbye.

123 The glass pane of the coffin was dazzling and reflected the clouds in the clear sky. I had to bend over to see through the glass. I saw grandfather's face but there was another face I saw. It was grandfather when he was young. I realized I was looking at my own image on the glass. Then when I turned, I found out I had lost Mother in the crowd.

124 The Filipino band started to play the Ave Maria again. I moved with the procession of mourners wondering where Mother and Ana were. The Chinese musicians started to play a Buddhist chant. It dragged heavily in endless rhythm. The people marched with the surging rhythm of the chant. Finally, reaching its climax, a gong struck: bam! bam! bam! Resounding in my diaphragm. Then I heard sobs. It was Mother walking right behind me.

125 “Ma," I tried to console her. I guided her as we walked.

126 We had gone quite a distance from our house. The heat of the sun began to prick our sweating bodies. The green fields spanned endlessly before us. I welcomed the scent of their verdure. As we turned into the loose gravel road that led directly to the concrete street, the smoke of the factories and tall buildings of the city appeared before us. The gray steeple of the San Agustin Church dominated the skyline.

127 The Filipino band began to play the Ave Maria again as we entered the Franco extension. People looked out of their windows and pedestrians stopped to watch us. The Ave Maria became louder. Then the Chinese band played another tune. The sounds were deafening me. My head felt like splitting. Mother leaned heavily on my arm.

128 At the shade of San Agustin Church the funeral procession stopped. Both bands had finally stopped playing. People began filing into the church. I saw Ana among them. I moved towards her but Mother held me back. Ana saw me and came to where Mother and I stood under the church portal.

129 "Why are we stopping here?" Mother asked suspiciously.

130 "We are offering a requiem mass for Grandfather," Ana said. 
131 Mother refused to look at Ana and turned to me, "Stay here, don't go with them."

132 The coffin was carried into the church by six men.

133 "Come, Ma," I held her arm to guide her into the church. She shook her head and withdrew her arm abruptly.

134 "Oh, I'm sick," she said faintly leaning on my arm.

135 We waited outside till the coffin was brought out again. The procession went on, again the two groups of musicians started playing.

136 We turned into narrower streets then to the forked path which led to the two cemeteries; to the left was the Filipino cemetery backed by adobe walls, to the right the Chinese cemetery spread out over the wide plains surrounded by tall mausoleums painted yellow, gray, blue, and white. The small tombs were lined with acacia trees on the left side. Six men carrying Grandfather's coffin past the yellow, blue, and gray mausoleums then stopped at the white newly-painted one. Another group of four men started burning strips of cloth on which the anagrams were written. The Chinese musicians began playing the same Buddhist chant they played at the beginning of the procession.

137 When an old man in thick glasses began to deliver his eulogy, Ana slipped into the mausoleum with a bouquet in her left hand, followed by Uncle Luciano who was carrying a large wreath near the coffin.

138 Mother screamed, "Hsin, there they are again! They are damning us!" She ran toward the coffin. I ran after her and held her back. She struggled from my grasp.

139 "I'll kill you, you devils!" Mother shrieked.

140 "Ma, please be quiet." My hold tightened on her as she struggled.

141 "Hsin, you are not helping me, let me go!"

142 "Mother, please!" I looked helplessly at the people staring at us.

143 "You are not my son if you don't let me go!" she was struggling fiercely from my grasp.

144 Ana came to us, "No, it's too late for you to stop us," her voice was hoarse, "it's too late!" 
145 Ana stood firmly almost fiercely in front of Mother. Then all of a sudden, her shoulders loosened as if all her ferocity was instantly depleted. "Mo... Mother!" she stuttered.

146 “No, Hsin, no!” Mother protested weakly.

147 Under the afternoon sun the coffin glared more intensely amidst the flowers. They were pushing the coffin into the tomb.

(The Sunday Times Magazine 42-48)

\section{Guide Questions:}

1. The conflict in the story is seemingly petty; however, to the protagonists, their fight is of paramount importance. An old Chinese custom forbids flowers during a wake because of the belief that in the dead's journey to the netherworld, he would be stung by the bees, and thus would be unable to rest in peace. Is this practice still followed today? Why or why not?

2. Unlike the West which considers the dragon as a fearsome foe, the Chinese regard the dragon as a genius of strength and goodness. It is the emblem of imperial power and is considered its symbol of vigilance and safeguard. Relate this to why Hsin's mother tried so painstakingly to glue the broken tea kettle decorated with dragons.

3. Readers are startled to read about Hsin's relationship with Ana, they being cousins. Generally, the Chinese forbid the marrying of people with the same surname. No matter if Hsin and Ana bear the same surname or not (depending on whether Grandfather Wang is a paternal or maternal grandfather), the story seems to be saying that their relationship, like assimilation to the Filipino way of life, is bound to be unacceptable and problematic to both. Discuss how the Chinese, represented by Hsin, can truly assimilate into the Filipino way of life. What are the possible blocks that could prevent such an assimilation?

4. What kind of man is Hsin? Based on the story, we know that he has been away for 6 years, making him around 22 years old. Yet he could not 
convince his mother to allow flowers for the funeral and burial. Can we dismiss this as a simple case of lack of will on his part? Why or why not?

5. Although a Chinese woman is generally subject to the dictates of men, she can wield great influence once she bears sons. In old age, although she is traditionally subject to her son's wishes, she usually has her way due to the importance given to filial piety in the Chinese way of life. Discuss the value of filial piety in the context of the Filipino way of life. How are the matriarch or the "lolas" of a clan treated in Filipino society? Are conflicts bound to occur, given how Filipinos regard the matriarchs of the clan? Would the same hold true in an American family? Explain fully.

6. Respect for the elderly is generally practiced around the world. Find out how Asians (like Indians, Koreans, Indonesians, the Japanese) differ in showing this respect. Do Chinese and Filipinos differ in how they show their respect for the elderly? Based on what you have read, where does a Chinese mother draw the line between concern and interference in her child's affairs? Explain.

7. In the story, Hsin is torn between his loyalty to his mother and his love for Ana. The choice between Ana and Hsin's mother can be viewed as a test of Hsin's determination to retain his traditional Chinese ways or to follow the Filipino way of life. In any case, the choice would cause pain and discord to all concerned. Aside from the question of flowers, cite, and explain all the possible areas of conflict between the two. 


\section{"How My Cousin Manuel Brought Home A Wife" by Charlson Ong}

He was the one called Ah Siao - the crazed one - who left the country many years ago, before Martial Law was declared, when I was not even ten. I remembered him as a gangling beanpole, with those dead dog's eyes that seem to be always falling off their sockets. The guy was believed to have inherited the genius of our grandfather who was supposed to have engaged in practical physics research back in China which eventually facilitated the splitting of the atom. Yet, Ah Siao drifted from one school to another finally dropping out of engineering college after his father, my father's half-brother, succumbed to diabetes. Ah Siao assumed management of the family's motor parts business but the store had to close shop a little over a year later. Crestfallen, the young man took the next flight to Hong Kong without his mother's knowledge and eventually ended up in Brazil where he supposedly became senior partner in an engineering consultancy firm. Now, after over two decades, my cousin Manuel was at last coming home with his Brazilian wife.

2 Aunt Mei Lu had rushed to our place upon receipt of Manuel's letter informing her of his return. Mother had opened a dimsum joint beside our home shortly after Father died of lung cancer and Aunt Mei Lu has always been our regular supplier of dumplings. Nearly 70, the woman remained prim and feisty. Marching about in her all-weather maroon pantsuit and brownish plastic clogs, Mei Lu could not put to shame people half her age with her perpetually straight-backed posture and 18-hour-a-day work habit. Now, she was a mass of nerves crushing Manuel's crumpled letter in her unsteady hands. Aunt Mei Lu had seemed to me suddenly shrunken and defeated. For once, her spine appeared weighed down by the years even as her powerful voice was clogged by phlegm and tears.

3 There was hardly been a contact between Manuel and his family since he left except for the occasional postcard from some unheard airports. He seemed to have drifted all over Europe and America. 
"He’s bringing home his Brazilian wife," Aunt Mei Lu said, nearly spilling coffee over Mother's new glass dining table.

5 "What kind of Brazilian?" Mother asked even as I recalled the bevy of bikinied beauties in the last Carnival-in-Rio movie I saw: buxom blondes, raunchy redheads, busty black beauties, mesmerizing mulattas; gyrating in their many feathered, multi-colored costumes in total abandon. Images of Sonia Braga washed over me in a wave of desire.

6 "I don't know," Aunt quipped, her forehead crinkling. "He didn't say." "A white woman, probably," Mother said.

8 Mei Lu's face folded in and for a moment I thought she would weep. "Twenty years he stayed away," she quipped, crushing her own words, fighting back tears. "Not one word. Not a single centavo he sent home to this old woman and his baby sister. Now he comes home with some foreign woman," Auntie shook her gray bobbed-hair head which must have weighed a ton. "Tell me, sister-in-law, what grave wrong have I done in my past life to deserve this?"

9 Mention of Manuel's younger sister Siao Mei - she prefers Samantha prickled me like memories of some childhood sin. Mother and daughter moved in with us for a year sometime after Manuel left and Samantha and I became quite close. At 17, Samantha married off to a rich widower in Cebu, some exporter of rattan furniture, after she spoke of working in Japan and Aunt Mei Lu feared losing another child to wanderlust. Samantha's untimely marriage saddened me but we weren't even sent plane fares for the wedding in Cebu and my parent felt slighted enough not to want to show up at all. Weeks later, Mr. Rattan exporter threatened to annul the marriage by charging that Samantha was "damaged goods," Mei Lu insinuated that I had something to do with Samantha's alleged deflowering and bawled me out. I literally swore upon Grandfather's grave that I was innocent of the charge but even Mother was difficult to convince. It turned out that the old fool simply changed his mind after meeting some Taiwanese songstress and finally clammed up about his ludicrous claims after nearly precipitating the worst scandal in the annals of our less-than-distinguished clan history. Still, it would be years 
before Aunt Mei Lu spoke to me again and I must admit to a lingering sense of loss whenever I remember my cousin.

10 “There, there, Mei Lu," Mother consoled Auntie. "He is a grown man, he has his own life," she said and reminded Auntie of our former neighbor whose son married rich Chinese-Brazilian years ago. "There are lots of them," Mother said and Mei Lu appeared to brighten for a moment. "Ranchers and planters dying to get their fortunes out of those banana republics. They're forever on the look-out for eligible Chinese sonsin-law." Mother concluded and Aunt Mei Lu at last sipped her cold tea.

11 In a touching gesture of sympathy, Mother volunteered my services in picking up Manuel at the airport. After Auntie left, I issued my perfunctory protest against Mother's usual solicitude at my expense, though the thought of seeing Ah Siao after all these years with Sonia Braga in tow wasn't exactly unexciting.

12 It was all I could do to spot a middle-aged Chinese-Brazilian amidst the welter of humanity crowding the arrival area, even with the latest photo of Manuel in my breast pocket. A delegation from Hongkong had just landed aboard a Cathay Pacific flight and the place teemed with Chinese- looking people. Manuel's flight had arrived too and I rose aloft my placard, waving every which way. MANUEL LIM: BRAZIL, it read.

13 The bespectacled, pony-tailed figure approaching me seemed lost and confounded, peering at me through horn-rimmed designer glasses. I was about to point him in the direction of the rest of the Hongkong gang when he stopped and blurted out my name in English. "Carlos... it is you. Look at you, you're all grown up.”

14 If this was Ah Siao then I'm Jackie Chan. Yes, he must have been at least twenty pounds heavier than the image in the photo I had with me, his shoulder length hair tied back in queue befitting the last emperor of China. Clad in fashionable white tweeds and slacks, my cousin Manuel could have passed for some Hongkong kung-fu star given a few more inches to his $5 \mathrm{ft}$. 5 inch frame. He wasn't as tall as I remembered but neither was he as robust and well-built. I felt my shoulder blade unhinge as he pumped my hand. 
15 "Such a big guy you are now, Ah Puy," I cringed slightly at his mention of my childhood pet name - Fatty.

16 "Manuel, putsa, I could've mistaken you for some movie star," I said in Chinese. Hindot, how many gold mines are you feasting on now?"

17 "Sssh..." he hushed me in mock confidentiality and whispered: "Dope, man. That's where the action is, haven't you heard?" His hearty fullthroated laughter reminded me of some medium-sized, oddly attired pro wrestler on TV. Something nipped my balls. I've never heard Ah Siao laugh this way. I've never heard of a nerd who never got anything going come home a winner.

18 “Where's your stuff?" I asked, "Let's get our butts out of this hell hole."

19 “Wait, my wife's with me," he said and rushed back to the luggage inspection area. For a while, Manuel's overpowering presence had banished all thoughts of Sonia Braga in me. But the mention of his wife pricked open some invisible bag lodged in my throat unleashing a horde of unseen insects to overrun every molecule of my being. My heart clubbed against my rib cage. Sonia, at last, sweet Sonia. Manuel took forever finding his way back and for an insane moment I thought he and my dear cousin-in-law had been mistaken for some stateless refugees and hide back to Hongkong. And then they were suddenly beside me.

20 “Consuelo, este e o meo primo. My cousin Carlos." He gestured with a flourish. "Carlos, mi esposa, Consuelo." She was huge and black. Perhaps among the largest women I've seen alive. At least six feet tall and no less than 200 pounds, Consuelo towered over Manuel like a giant, a smiling genie from some ancient Amazon bottle. Wrapped from head to toe in yellow-green robes speckled with bluish globes, and white stars, her massive breasts - which would have filled an entire wok as mother used to say - and an arms heaved with the slightest laughter. Foot long earrings of oyster shells and canine teeth adorned her ears even as her perfect teeth shone in a solid arc of triumph. Her eyes were onyx marbles in a sea of white. This was Mother African-Brazilian in person and her presence attracted not a few curious souls. 
21 I was glad I brought the van. Something told me that twenty years' worth of baggage would never fit into a bantam Toyota - God only knows how Consuelo would have squeezed into those mini bucket seats, "I speak little English..." she said to me in a scratchy, high-pitched baritone and I suddenly thought - Billy Holiday.

22 “Do you sing?" I blurted. A frown crossed her face as she smiled and launched into a spirited rendition of El Condor Pasa - I remember the Simon and Garfunkel version - and Manuel joined in after a few bars. I turned on the radio to drown out the deafening duet and had to play tour guide to Manuel the rest of the way to Aunt Mei Lu's, explaining the monumental changes that have overtaken Metro Manila from garbage heaps to nomadic street children. He wanted to know if they could still play the slot machines along Roxas Blvd. Where's "Bayside"? Where's the Flame? Who's Robin Padilla? What's “shabu”? What's the PBA? You mean Jaworski's still playing?

23 The couple spoke mostly Spanish - or was it Portuguese - to each other although I wasn't sure if Manuel was relaying any relevant information about his old city to Consuelo. And then, glimpsing my rear view mirror, I saw the grayish wooden stumps he pulled out of his right pants' pocket. My insides froze for a second. Ever since our meeting at the airport Manuel had kept his right hand inside his pants pocket. He carried his bags, squeezed my shoulders, pumped my hands all using his powerful left hand. I'd thought it a strange Latin affection he'd picked up until then.

"What's that?" I asked. "What?"

25 "What's that in your hand?"

26 "Oh?" he quipped, raising his stump. "I lost it in an accident while working in a logging concession in the Andes many years ago," he explained. "Three days before we were to leave Manila some mugger did off with my silver-plated artificial limb.”

27 Manuel said something to Consuelo and they burst once more into their hearty baritoned laughter. I forced a smile, but the coldness clung to my bones. I was trying to conjure in my mind's screen the impending 
homecoming scene for Ah Siao. So his mother might forgive him for two decades of absence and neglect. So might she even learn to live with the fact of a foreign daughter-in-law, Spanish speaking and all. But Consuelo? The woman simply failed to strike me as being in the universe of possibilities Aunt Mei Lu could imaging. She was, after all from an age where the word "beauty" conjured a fairness often described as "being edible" and where petite, teenage, virgin brides were tucked neatly into fragile sedan chairs fit for babes.

28 I turned the radio on a bit louder as a zamba revival came on the air with Consuelo and Manuel sashaying their upper torsos to the beat. The music kept my mind off dire possibilities and on the narrowing road.

29 The last time I saw that look in Mother's face was when our sliding glass doors came crashing down at the height of typhoon Yoling in '73. As for Aunt Mei Lu, it seemed her entire apartment unit had caved in on her. The two women were speechless and seemingly stunned while Consuelo smiled in her soulful way and Manuel hugged his mother as though he would an unmoving mango tree. I've never known Manuel to be capable of such expressiveness and cringed even as Mei Lu remained rooted unto her granitic flooring. I turned to Mother and saw her glaring at me. I winced. She seemed to be blaming me for everything that was going on. In a willful moment I blurted: "Consuelo, this is my mother Rosario. She's been dying to meet you. She's a soprano." I took Consuelo's large hands and guided her to Mother who was now scalding my aura with her laser beam stare. Mother managed a tortured smile, though as Consuelo hugged her and orated in Spanish.

30 "Excuse me," Aunt Mei Lu mumbled to no one in particular. It seemed she wanted to say more but appeared dazed and dumbfounded. She was gesturing to us to be seated. Mei Lu turned to cousin Manuel as to some crass stranger, then she looked at Mother and sort of scampered off into her bedroom. "She's not feeling all that well," Mother said in Chinese to Manuel "Oh, is she sick?" Manuel seemed truly worried. "Oh no, she's just a bit fatigued." 
31 Manuel explained the situation to Consuelo who rattled off something in Spanish and quipped: "I can help, maybe?" her words appeared to have struck Mother like a phantom blow and for the first time since he arrived, Manuel seemed lost. "It's okay, Consuelo," he whispered "Ela esta so umpouco cansada." Mother said she was looking in on Auntie.

32 Left to play host to the domicile's rightful inhabitants, I learned Consuelo was some kind of healer. I figured it had something to do with spirits and psychism but did not pursue the matter. I'd accompanied my own father to two dozen healers - everything from Sto. Nino mediums, to drunken Taoist masters and chi kung experts from China and assorted pranic practitioners - after cancer experts had given him a paltry six months to last. Most of these so-called alternative cures had struck me as honest delirium at best and criminal misrepresentation at worst, but I had enough of a scene in my hands to risk Consuelo casting some voodoo curse on me. I let half an hour pass before deciding to look in on the two women.

33 "Get out, stay with your cousin," Mother yelled as I entered. Aunt Mei Lu was weeping and slapping the bed.

34 "What's going on?"

35 "Are you deaf?"

36 "He's home with his wife after twenty years and you're carrying on like someone died."

37 I might as well have poured boiling water over Mai Lu as she burst into a bone-piercing feline wail. Mother was really mad at me now. "Carlos, I will not tell you again..."

38 "What awful deed have I done to deserve this..." Auntie asked mother for the umpteenth time."

39 "What's wrong?" I asked. "Your son and daughter-in-law are home."

40 Mother threw something at me, missing me by an inch while Mei Lu wailed, "You could tell she was loading up whenever she took calling me by my Chinese name. "Why did you bring them there, you idiot?"

43 Mother's query clawed away my last skin of good humor." What?" I nearly choked. "Where was I supposed to bring them?" 

hurl another projectile my way when Mei Lu wailed: "O ke kiam tua kho waah..."

49 "Big and black...big and black," the woman moaned like some professional mourner weeping over a mutilated corpse. "She's bigger than the Great Wall and blacker than the pit on my kettle."

50 "She'll bear big children," I blurted and Mother had more or less given up on trying to control the whole scene. "Big and black..." Mei Lu kept on. "Big and black children. Oh...Ah Di ah, what have you done? Why didn't children you look after your only son? Are you too busy laying women in the netherworld or burning in hell what you allow this tragedy? What will your ancestors say? How am I to face them? They will tear me to pieces in the afterlife and curse me till eternity's end..."

51 "You know how much they make these days in the NBA?" I rambled on but Mother was beyond riling, "Carlos, please. This may all seem very funny to you, but it isn't. It really isn't."

52 "She's a healer," I said.

53 Mother scowled: "What?"

54 "She's a psychic healer. You know voodoo stuff... zombie specials..."

55 Mother attacked me with the folded 20-page classified ads of the Sunday Bulletin, forcing me out of the room.

56 The changes in domicile that occurred during the following days was pure sitcom that only Mother could have scripted. She invited Aunt Mei $\mathrm{Lu}$ to vacation for a while in our place and "recuperate" while allowing Manuel and Consuelo some "privacy." And school being a few weeks off, and since I wasn't exactly an indispensable item at the restaurant and since I was dumb enough to have driven them straight home and would be needed, anyway, to drive them around for the rest of their stay, why 
don't I just check-in with my lovely cousins at Aunt Mei Lu's for the nonce?

57 It wasn't much of a chore driving the couple around town. In fact, it got to be quite enjoyable. Manuel was more than I've ever known him to be- though I didn't get to spend too much time with him as a boy-while Consuelo was a real knock-out. She laughed at every oneof my poorly-translated jokes, sang Sergio Mendez classics and told my fortune every day. Being stared at constantly inside malls and restaurants provided some sense of celebrity even as I began to pick up a spattering of Spanish.

58 Manuel seemed dead set on catching up on his Filipiniana - anything from basketball to politics. He was particularly curios about the psychic scene. He said they've heard quite a bit about the Philippines "wonder healers" from German to Japanese travelers. I relayed to them as much as I knew about the matter. The fact that I was largely skeptical of these alleged wonder may have somewhat dampened their inquisitiveness but I did promise to introduce the couple to some experts.

59 I too was able to get Cousin Manuel to tell me about his sojourns. Manuel told me how his life took a drastic turn about a year ago when he sailed down the Amazon with a group of surveyor while working on a government project. Manuel said he became comatose after being bitten by some rare tropical insects and nearly given up for dead by his companions when an aborigine brought them to Consuelo's village. A known healer, Consuelo could not then practice her medicine as she was recently widowed. But the woman decided nonetheless, to break tradition and heal the Oriental person who she had not long ago seen in a vision. Consuelo applied an antidote and Cousin Manuel recovered. Manuel said he awoke a changed person. "I fell in love not only with this wonderful woman but with the entire village, the rain forests, the tranquil Amazon," he encountered nearly teary-eyed. "This was it. I knew at once it was what I'd been searching for all my life. I stayed in the village for several months before returning to Rio de Janeiro. I'm 
thinking of selling off my shares in the firm and moving to the Amazon permanently."

60 "Wouldn't that be a bit drastic?" I quipped.

61 But Cousin Manuel was off somewhere in the Amazons.

62 "You wouldn't know how it's like until you get there, Carlos," he said. "I grew my hair long to gain power, put on weight and found my center. Everything I am now owe to Consuelo," he beamed and I could swear that for an instant, Cousin Manuel's face emanated an unearthly glow even as the midday sun shone through our tinted car windows.

63 "I am his black star," Consuelo declared and I caught the twinkle in Manuel's eyes. I remembered at once how my cousin used to drag around his telescope through which he'd peer at the sky at odd hours of the night. He was an astronomy buff back then and could name every one of the constellations which he pointed out to me save an object he dubbed the "black star." I remembered Manuel telling me that he'd made an astounding discovery and he was willing to name the "undetected quasar" after me for my entire personal savings worth P250. Yet try as did, I simply couldn't sight this black thing Manuel seemed genuinely ecstatic about. Years later, while reading about Imelda Marcos' celestial musings, I wondered whether cousin Manuel wasn't imagining some black hole in the horizons way back then. The International Astronomical Society never acknowledged Manuel's letter informing them of his discovery and he'd soon trade off his telescope for a super 8 movie camera.

64 I was glad Manuel finally found his black star. It was a tale befitting a television mini-series the way my cousin related his adventures and I marvelled at the man's daring and survival qualities. I who would never dream of cooking my own meals, much less hunting for them, could never live half the life Manuel had had.

65 It would take me long, too, to witness first hand Consuelo's healing abilities. Manuel had been complaining of the heat since his arrival. He said Manila's humidity was a different sort from that of the Amazons and he was often short of breath. I suggested for him to have a medical 
exam but he thought he was just experiencing an overextended jet lag. Anyhow, he was deep into "wholistic healing" with his herbs, and crystals and Consuelo. I realized soon that cousin Manuel wasn't as trim as his designer suit made him appear initially. He was a bit on the plump side and ate like a recently released hostage. Either the months in the Amazon had really pumped up his appetite or the guy was trying to gobble up enough local cuisine for another twenty years of exile. Three days as a balikbayan and Manuel's bowels were threatening to go on strike.

66 We were halfway through our native meal of steamed oysters and crab when Manuel suddenly turned blue and his eyes nearly popped out. He was grasping for breath holding on to his neck and tumbled to the floor. The restaurant was frenzy and the manager was shouting at someone to get a doctor when Consuelo issued this bone-piercing wolfish cry stunning the whole place into silence. The woman picked up my fallen cousin and sat him back on his chair. He places her large hands beneath his chest and gave him a couple of pumps and I could see Manuel's black iris settling back in place. She asked for a raw egg and was finally given one after some commotion. Consuelo held the egg about a foot from Manuel and passed it over his body as if she were sketching an invisible outline of Manuel in thin air. Then she started blowing away what she had seemingly drawn and cracked the egg on Manuel's brow. Some of the egg yolks dripped over his head as Consuelo whispered something into Manuel's ears. Manuel's eyes began rolling as Consuelo once more placed her hands beneath his chest, shrieked into his ears and pumped P350 worth of seafood out of him.

67 The episode unnerved me. It was my closest brush with death since fraternity initiation rites when a blindfolded neophyte leapt into a waterless pool. I insisted that he see a doctor but Manuel was adamant against it. He explained that Consuelo was cleansing his aura with the raw egg. The individual, he explained, consisted of several body was supposed to be the "grossest manifestation" while the higher soul was of the subtlest and highest frequency. All nature, all reality, is vibratory, my 
cousin Manuel said. And I suddenly recalled the times he would lecture me on the thermodynamics and the general theory of relativity. More than anything, Manuel was a teacher who was never more passionate than when explaining the finer points of some theory or other. Before any disease manifests itself in the physical plane it first shows up in the etheric body, Manuel pointed out. Therefore, one needs only to heal physical sickness, he concluded. I nodded. Whether he made sense or not, Manuel could overwhelm you with the sheer passion and seeming clarity of his exposition. It was futile to argue with him once his made up his mind to be correct. I'd seen stranger "healings," and as long as the net effect was curative, I couldn't care less whose medicine was bogus. Still, I didn't think a blood test would alter the frequency of anyone's higher soul. But Manuel would sooner die than be taken to a hospital. It was Consuelo he was rather worried about. The woman was large, hypertensive and asthmatic. She had already "died” twice in her life according to Manuel, reawakening each time with even greater powers.

68 "It was a simple case of heartburn," Mother concluded after listening to my animated recounting of Manuel's apparent near-death experience, while Aunt Mei Lu was convinced Consuelo had it in mind to kill off Manuel and inherit his fortune.

69 "She saved him," I protested.

70 "Your aunt has a point," Mother mused. "We might not have any legal claims to Manuel's properties in Brazil in case anything happens."

71 "Mother," I blurted in exasperation.

72 “Are you so sure that it's still my boy inside that strange body?" Mei Lu turned to ask, tears welling in her eyes.

73 "This is way beyond my league!" I muttered and resolve to have nothing more to do with my displaced, cross-cultural cousin once I had introduced them to psychic researcher Renato Corrales.

74 I had met Corrales at a party thrown by a good buddy, Dwight Lim who had a dwarf allegedly exorcised from his family's perennially distressed factory by one of Renato's wards. I invited Renato to meet with my cousin and he readily agreed. 
75 What was supposed to be a restricted affair turned into a virtual press conference. Corrales brought along a bevy of fellow researchers, psychics, features, writers, and assorted groupies turning Aunt Mei Lu's apartment into a human sardine can. Everybody wanted to know about this "black widow from the Amazons." Dwight was also ecstatic about after she'd predicted his forthcoming marriage. I took the loudmouth aside and shouted into his ears: "She's now a widow, you moron, she's my cousin-in-law. I curse you this day. May your low-grade, hazardous, environmentally unsound refugees' camp of a factory turn into a nursery of evil black dwarves.”

76 In the midst of the unscheduled press conference, a fiftyish woman with acute arthritis was wheeled into the apartment from the van outside. It appeared someone had gotten wind of the occasion and had sent word to the woman that some sort of healing session was going on. Surprised, Consuelo demurred. She wasn't in the proper frame of mind. But the woman pleaded with Consuelo and Corrales egged her on. Someone brought out a video camera which Manuel promptly banned from the gathering.

77 Although bothered by the crowd, I too was admittedly eager to see more evidence of Consuelo's powers. The woman had seemed candid and low key enough about her abilities. It was Manuel who struck me as being bent on making a public show of the matter.

78 Consuelo fell into a deep trance and Manuel silenced the gathering. After nearly ten minutes she began to shake mildly, then violent and frothing at the mouth in epileptic like seizure. "Let us all pray," Manuel said igniting Babel of murmurs. He held onto Consuelo and Corrales rushed to his aid. Consuelo opened her eyes and stood up. Her eyes were unblinking and her face was stone. I felt a sudden gush of warm air on my face. She began passing her hands over to the woman the way she had done so with Manuel at the restaurant before asking for an egg and breaking it over to the woman's head. I could see the woman grimace as the egg white streamed down her face. Then Consuelo knelt in front of the woman and began passing her hands over the woman's legs before 
laying her massive hands upon them. Consuelo massaged the woman's legs vigorously before standing up and holding out her hand to the lady. "Lavante-se..." she ordered. "Stand up. Stand up..." Manuel whispered into her ear but the woman merely stared at them desperate and confused, shaking her head, tears brimming in her eyes with eggyolk all over her face. "Levante-se," Consuelo shouted and the woman burst into tears. The weeping got to Consuelo and she appeared to be snapping out of her trance, breathing hard and staggering, but the crowd wasn't about to let her off easy.

79 "No mas, no mas," she whispered shaking her large head, the yellow-gold bandanna at last failing off revealing short cropped hair rather than the huge curls I'd expected. And I was at once reminded of Roberto Duran walking the away exasperated from a clowning Sugar Ray Leonard in that classic lightweight title rematch. "No mas, no mas."

80 "Come on, Consuelo, give it one more slot," Corrales said. "Yes, she's almost cured.” Another whispered, "Please, don't stop, save her.” It was now a chorus urging her on as Consuelo face the wall, turning her back on the crowd. Suddenly a low moan was heard, seemingly emanating from the wall. Then Consuelo belted out that skin-shearing cry of some wild cat being skinned alive, stunning the gallery. She turned around and strode towards her patient - 200 pounds of fierceness. Fear infected the lady as Consuelo slapped her. She was too stunned to react; eyes nailed on the massive blackness before her. In a moment, Consuelo was overcome by a numbing gentleness laying a finger on the woman's forehead. "Levante-se...!" she whispered, gentle and deep "Levantate!"

81 The room was cast in deathly silence as the woman grabbed on to Consuelo's arm and slowly pulled herself up from her wheelchair. She was anything but puny standing beside Consuelo hanging on to the healer's shoulder. Consuelo held on to her as she took her first tentative steps and then she was walking by herself, wobbly, as a child walking for the first time. "I can walk," she declared in seeming disbelief, "I can walk," she repeated overcome with joy, "after all these years." She turned to Consuelo and kissed the copper medallion with an inscribed image 
of the Virgin Mary hanging from the healer's neck. "Bless you; you are an angel of the Lord." She was trying to genuflect before Consuelo but the large woman stopped her. "Vaya con Dios," my Brazilian cousin told the lady who strode to her van, normal and joyful, but for a slight limp, followed by cheers and applause. The lady's male companion produced a red a packet which he tried handing Consuelo as if making an offering to some black icon. Consuelo shook her head. "Give it to charity," she said, but cousin Manuel are on top of things, deftly packing the red packet from the guy's hands. "Let's make this an offering to the Sto. Nino," he said, pointing to Aunt Mei. Lu's statue of the infant Jesus surrounded by a cloud of incense smoke. "Thank you," the man uttered and the gathering fell into a deep silence before Consuelo said in English - "Let us pray," - and the murmurs returned.

82 The tale of the "black widow from the Amazons" would spread during the following days. Consuelo was featured in a number of newspaper articles and over a week later a television crew would come over to cover one of her healing sessions. The woman seemed embarrassed over the publicity and refused interviews, relenting only upon Manuel's impassioned prodding. Manuel's new found affinity with media was beginning to bother me and I approached him right after the third TV crew left. "You intend to stay long in the country?" I asked.

83 "Who knows?" he answered, almost dreamily. "God works in mysterious ways. I might have found my true calling," Manuel became reflective. "After all these years... strange, only to come home and..."

84 "Is this what she wants?" I butted in.

85 "The Virgin Mother has chosen to work through Consuelo and this is her consecrated land."

86 It was the first time I heard Manuel mention the Virgin Mary and I thought he might have picked up a few pointers from Corrales and his gang.

87 "But, Consuelo..."

88 "Consuelo wants what I want," Manuel blurted a mite impatient and I felt my face burn. "Let's have that again?" 
89 A slight sense of panic rushed across his face. "No..." he stammered, catching himself. "I mean, Consuelo knows I look out for her best interests."

90 "You think all this is in her best interests?"

91 "You seem to dislike her, Carlos," Manuel said with some pain in his tongue. "I thought you were different from the old people. That you understood."

92 I was picked by the injustice in his tone and nearly screamed - "I don't dislike her. I think she is a fine woman and I think you're using her." This really got to Manuel and the middleweight wrestler of a man collared me. "Don't you ever say that again," he said with rocks in his throat, mashing his teeth and mice scurrying beneath the skin over his biceps. And just as I thought Cousin Manuel was to pluck of my puny head he dropped me like a hot potato. "I'm sorry," he quipped truly confused and apologetic. "I'm terribly sorry, you're right."

93 "No," I barked. "I was out of line."

94 "You're right, this is all too much. Things are going too fast. I never expected this. Perhaps we should leave."

95 "No," I said without knowing why. "What's the rush? I mean you've got a well-established business back in Rio. I'm sure you have people to oversee things while you're gone?

96 I immediately regretted having encouraged him to stay on as good sense overcame survival instincts and cousin Manuel, too, was back to his mild-mannered ways. "Let's give it a few more weeks," he said and a sudden load of weighed down my bowels.

97 Next day, Mother and Aunt Mei Lu were at the apartment shortly after sun-up. They began burning spirit papers by the doorway; yellowish crepe paper issued by Sian $\mathrm{Di}$ - the alleged spirit medium of some red-faced Chinese deity. They were all-purpose talismans that were used to ward off all sorts of evil and ill-luck. Aunt Mei Lu would occasionally burn a few sheets, mixed with ashes and water and drink the liquid to cure her migraine. I knew something extraordinary was up.

98 "What are you doing? It's five in the morning," I asked. 
99 "Stay out of the way," Mei Lu ordered. "You're blocking the path."

100 "What path?"

101 "The path of the spirit."

102 "What are you calling on spirits for this early in the day?"

103 "We're preparing the way for the spirit to come and exorcise the evil presence," Mother said, her face a mask of concentration.

104 “What evil presence?"

105 “The black One,” Mei Lu said dead serious.

106 The scene would've been loudly comical if not for the anger written all over the women's faces. "Mother, stop this." I blurted in exasperation. "I can't believe you'd take part in such nonsense."

107 "I can't believe you haven't got rid of her yet," she shot back.

108 "What am I supposed to do with her? She's my cousin-in-law."

109 "She's a witch."

110 "She's a healer. I saw her cure with my own eyes. She'll be on TV."

111 Awakened by our voices, Consuelo and Manuel were soon standing with us at the door. I was certain that Manuel knew what was happening but it was Consuelo all excited over the strange ritual. She kept asking her husband about the scene until Manuel whispered something to her in Spanish and she suddenly smiled widely, her eyes lighted up. She took some spirit papers from Mother and examined them carefully before joining in on the burning. Mei Lu's face was askance. She threw dagger looks at Manuel and marched to her domicile, locking herself up in the bathroom. Consuelo couldn't contain her excitement, lighting up the yellow crepe paper and hurling them into the wind as Mother looked on in dismay.

112 Nearly an hour later, Sian Di herself arrived with her lady assistant. Standing a mite under five feet, wrinkled skin stretched taut over squarish bones; the sixtyish bobbed-hair woman exuded an eeriness that argued as much saintliness as malevolence. Chanting Taoist sutras, the four women entered the apartment, incense smoke rising from the urn borne by Sian Di's assistant who seemed to be sleepwalking. Sian Di would scoop incense from the urn with a small spade and scatter 
them every which way. The sickish smell stuck to my throat and my eyes began to sting from the cloud of smoke that had transformed Mei Lu's apartment into a temple. I could see something was eating Manuel but Consuelo was ecstatic. She tried participating with the chanting until Sian Di turned on her suddenly and screamed. The living room was thrown into deep silence at once. And just as I thought Consuelo was about to return fire, the big woman laughed. She laughed ceaselessly, she laughed hungrily, all 200 pounds of her shaking violently. We were all of us stunned turning to Manuel who merely twitched his shoulders. Desperate, Mei Lu rushed towards Consuelo and yelled into her face, though at a respectful distance. "O kui, o kui," she shouted, calling the large woman a black devil. Consuelo seemed to have gotten wind of her mother-in-law's drift and turned to Manuel with a slight scowl. Manuel whispered something in Spanish and scowl once more gave way to a hearty laughter. Consuelo approached Mei Lu, nodded and placed her large hands - bedecked with all varieties of brass rings and bracelets gently behind the smaller woman's nape. "Gracias," she said beaming. "Gracias." Dumbfounded, the women stared at each other, seemingly confronted by something truly otherworldly. I guessed Manuel told her this was some kind of grand welcome ritual for her. As the quartet retreated into a corner in utter disbelief. I could see Manuel's face turn ashen and grim while Consuelo was never happier.

113 The next two weeks saw more Consuelo's healing and media coverage of this Brazilian wonder. She worked on cripples, cancer patients and heart conditions and few went away without some sense of relief and recovery. Her laughter, too, proved infectious just as her silences and sudden scowls elicited a sense of danger and morbidness in me.

114 Manuel was determined now to host our clan reunion that Mother had been postponing since Consuelo arrived. I was certain any official recognition of her foreign daughter-in-law would have to be done over Mei Lu's dead body. But Manuel already sent out words to gather the kinsfolk at a Chinatown restaurant for him to show off his wife and foreign fortune. With all the media coverage the couple had been 
receiving, it would've been a wonder too, if most of our relatives hadn't already heard of Consuelo. A health buff, Mei Lu's slight diabetic condition had alleged worsened since Consuelo's arrival according to Mother - an admittedly unreliable source. The woman's heart had also supposedly been skipping a few beats for the past few months. Whatever her true condition, I was sure Mei Lu wouldn't be caught anywhere near Manuel's "lauriat."

115 The party started out as a subdued enough affairs, quite uneventful save for the "monk-leaping-over-the-fence" soup. I didn't notice many raised eyebrows as Consuelo stood by the restaurant door to greet almost every one of the nearly one hundred guests. It was supposed to be a homecoming cum post-wedding reception for the couple.

116 But soon enough, my second degree cousin, Winston - a budding theater comic who's been embarrassing his Protestant parents by caricaturing the Pope on primetime TV - who was hosting the sing-along side show asked Manuel for a Brazilian long song. Manuel obliged with what sounded like a cross between "Jealousy" and "Eres Tu", and before long Consuelo had joined him and it was a "Carnival-in-Rio forming in the heart of Chinatown, Manila.

117 Shortly after dessert, a waiter called Manuel to the counter. Mother had phoned telling him that Mei Lu had been rushed to the hospital after suffering a stroke. We kept the news to ourselves though I was certain Mei Lu and Mother's absence didn't exactly go unnoticed. Manuel urged me to take Consuelo home while he rushed to the hospital and I agreed. At home, Consuelo looked puzzled. She'd thought we were going to the hospital in a separate ride. She quizzed me continually until I relented and told her the whole truth. "I can help," she said in English, deeply disturbed I suddenly wanted to cry. "I can save her," she repeated. "Many people I saved from stroke, heart attack," she went on. "Why not I go to the hospital? Why not we go?"

118 I didn't know whether or not to give her the lowdown, "listen, you're probably the main reason she's in emergency." I decided my Spanish might have worsen things and clammed up. "Let us pray," I finally 
blurted. "Maybe you can help her from here," I said. Consuelo got my drift and seemed to enter into a trance that made me draw a map detailing the route from our place to St. Martin's Medical Center. Consuelo made a metal note of my sketch and slipped back into her trance. I guess she was bilocating or doing some sort of astral travel. After several minutes, a soothing smile broke across the woman's face as she rubbed her palms. "It's alright," she whispered, eyes closed. "Muy bien. No problem, no worry. She will live. Ela vivira!” on that note, I bade her good night and rushed to St. Martin's.

119 Aunt Mei Lu was lying comatose inside the intensive care unit hooked to a network of monitors and bottles. I caught Manuel and Mother sitting at opposite ends of the cushioned bench outside the ICCU. They were probably blaming each other for Mei Lu's condition. I found my loyalties split down to associate instead with a coffee machine. And there she was, slightly heavier the last time we met, her eyes sad and brilliant, her lips caught in a strange half smile that sent moths fluttering in the moonlit nights many seasons ago.

120 "Hello, Sam. How are you?"

121 "Hi," she whispered looking away as the two moths circled the light. "seems we'll finally see some rain." I whispered walking her to the hallway. "I'm sorry for your mother, I wish we'd met under happier circumstances. But it's really great to see you after all these years."

122 I'd always remember Siao Mei for her light headed spunk now her silence was alien and unnerving. "You're looking fine," I trying desperately to strike up a conversation. "You too," she finally said.

123 "So how's the family?" I asked, trying to keep her increasing pace. She seemed to be leaving the premises.

124 "They're all here."

125 "I mean your family."

126 "Well Nic-nic will be turning four soon you should see him sometime."

127 "Where is he?"

128 "Home. In Davao. I wasn't sure what I'd find here so I decided to fly over by myself." 
129 “Davao?”

130 "I've resettled there... after the split."

131 "Split?"

132 "We've separated," she said, looking at me for the first time and I felt sudden pain in my back. "I'm sorry."

133 "I'm not," she shot back and I knew she'd lost none of her teenage spunk only sharpened it with a more deliberate, hardened pose.

134 "What happened?"

135 "Nothing. I had enough of the old goat and cut him loose."

136 "So where is he?"

137 "Beats me." She shrugged in that taut boyish manner and all the tension that had been piling up in me after nearly a month of voodoo, zamba, Amazonian tales, and shaman wars melted into a confused tenderness yearning to flow out through my every pore. I hugged myself to keep my hands from touching her and caught glint in her eyes.

138 Last I heard he'd hide off Taipei to shack up some singer. Are you cold?”

139 "I'm a bit under the weather, nothing serious."

140 I've learned enough of the rattan business and decided to set up a shop in Davao. Labor costs are manageable, adequate supplies... I'm hoping to export by next year."

141 “That's something... I mean your own business, you're so young...”

142 "Not so young."

143 "Younger than me,"

144 She twitched her bare shoulder again and I had to grab on more desperately in my arms. "Listen Sam, I know there have been misunderstandings between our families. Some of the old people got things wrong and...”

145 "I don't want to talk about these things, Carlos. Not now. I'll see you sometime."

146 "You're leaving?"

147 "Ya. I don't think mother will regain consciousness very soon. I'll go get some sleep at the hotel." 
"Hotel? Why don't you stay with us? Or stay with Mother? I mean my Mother has actually been staying with your mother ever since your brother got back."

149 "No thanks. This is better. I want to be alone."

150 Mother had entered the ICCU to check on Mei Lu while Manuel was now slumped beside the coffee machine. The air-conditioning had conked out and Manuel had taken off his jacket - the first time he had done so in public since arriving - and his wooden stump straddled his thigh like some decayed organ. In the half-light his scars appeared to be etched deeper into his skin and he looked suddenly lifeless. It struck me for a moment that I was looking at some ancient Aztec deity of stones, terribly worn down and deformed.

151 “I met Sam. She's left for the hotel," I said.

152 But Manuel didn't so much move his stone head to recognize my presence. Mei Lu's sickness had seemingly driven the verve out of everyone. "Pretty as ever."

153 "I really like your sister," I ramble on, reminded of the times I, a declared agnostic, would wander into some empty church to chat with statues I was certain couldn't care less. "They lived with us a while, a few years after you left. We became close.”

154 Manuel finally turned to me. I caught the violence in his eyes and looked away. "So you were," he mumbled gravely. "Listen Manuel, you might as well hear it from me," I stuttered. "There were some silly talks about us..."

155 "So I've heard," he butted in. "There's a time to be foolish," he said. "It's okay, I know it's nonsense. Forget it." The ensuing silence was both deadly and ivied. And it was too late to hold my tongue. "I might have been in love with her."

156 "You're nuts."

157 "I was."

158 "You were kids."

159 "I was fourteen and she was almost fourteen."

160 "Did she know?" 
161 "Your mother got wind of things, I think and moved out. We never heard from them again. Next thing I knew, Sam was marrying this old fart in Cebu."

162 "Good thing."

163 "Christ, if I had half your balls I'd have done something about it. I'd have looked for her sometime and faced up to your mother."

164 "Stop it, kid. I was the one who ran off."

165 "I know it is what you would've done."

166 "She's my sister, Carlos. You're first cousins. What on earth are you saying?"

167 "My father was adopted. The old people know that."

168 "It doesn't matter, you pumpkin brain. You carry the same name. It can't be."

169 "I love her. I know that now."

170 "You really want to know what I would have done if I were around?"

171 "You'd have understood."

172 Cousin Manuel leapt off his feet with a powerful kick. The statue at last imbued with the breath of its vengeful spirit. "Shit," he blurted, exasperated. "You're really mad." And pointed at me menacingly with a stump. "You even bother my sister again, Carlos and I will kill you. I swear to God I will.” Manuel strode angrily towards the ICCU and I saw he was limping.

173 I had the mind to quit the premises before Manuel came back at me with pre-emptive strike but I was worried about Mother and decided to hang around a bit longer. Half an hour, I saw Manuel standing outside the ICCU, resting his head against the glass doors. I approached him with a fresh glass of coffee.

174 Manuel looked at me with sad, tired eyes and received my peace token. "I'm sorry," he said.

175 "What for? Your mother is the one lying inside."

176 "It's all my doing."

177 “Come on cousin... it's nobody's fault." 
178 "I've lost everything, everything, Carlos. I've screwed up my life and everybody else's. I shouldn't have come home.”

179 "Nonsense, your mother will be fine. Consuelo assured me herself."

180 Cousin Manuel glared me for a while I thought his face folded in but he looked away and took deep breaths.

181 "You've got a good life waiting for you back when you get back in Brazil. You can always liquidate your assets and move back here. Set up some business. There's lots of things you can do with a couple of million dollars. You've done really well, guy, really.”

182 “There isn't any business in Brazil, Carlos," he mumbled.

183 "I ran into a lot of debts with some harebrained schemes. Borrowed heavily from a drug lord and couldn't pay up so I hid in the jungle. They caught up with me, shot me and left me for dead. That's when some villagers took me to Consuelo. She nursed me back to health. I stayed on in the village because there is nothing left for me in Rio save debts and death threats. Consuelo's a good woman. I know you're not much of a believer but I really think she's got something. I've seen her do some really fantastic things."

184 Manuel's revelations hit me like a phantom punch. I was at once weak and empty. "Anyway, I was able to convince her people to let me sort of market her services..."

185 "You're managing her?"

186 “Well, sort of. Nothing grand. It's a service, you know and we both deserve something. Anyhow, we got by and things appeared to be picking up for a while. We got some good press and before long Japanese tourists and German cancer victims were making pilgrimages to our village. Then this mistress of some army general was brought to us. She was dying of leukemia and Consuelo was able to cause a remission. The general's wife heard it and came down hard on us. Two months later, the mistress dies and the general accuses us of murder and drug trafficking. We had to leave."

187 It turned out that Consuelo was traveling on a stolen passport and fake visa while Manuel under an assumed name. "I thought perhaps we 
could start a new life over here. What with all this craze about spiritual healing... and now this," Manuel was on the verge of tears.

188 "I'm jinxed, Carlos, I'm cursed," he spat. "Everything I touch turns to shit. I should lose this other hand too," he said and began chopping at his good hand with stump until I grabbed his arm. "I haven't done anyone good. I haven't done anyone any proud in my life. I lost my father's business, ran around empty for twenty years and come home to destroy everyone's lives..."

189 "Don't be too hard on yourself," I whispered though every word he said rang true.

190 "My mother is seventy and rolling dumplings. My sister had to be married off to some son-of-a-whore widower. And here I am, trying to live off the only person, outside my family, who's been halfway decent to me."

191 "I think you're a grand pair... really." I said.

192 And just as I thought cousin Manuel would throw himself against the glass door, in marched Consuelo, striding across the hallway like some ancient African queen. A massive black will clothed in green and yellow. We were both too stunned to react as Consuelo pushed her was through the glass doors and marched right into the ICCU.

193 Consuelo's face softened as she saw Mei Lu. I remembered seeing tears in her eyes. She approached my aunt and caressed the comatose woman before issuing her high-pitched cry which turned the heads of the two of the other three patients in the ICCU. I rushed over to close the glass doors less the nurses and resident physician got wind of what was going on and Mother drew the curtains around Mei Lu's bed.

194 Consuelo had her hands over Mei Lu and began wiping away invisible blockages. She produced an egg from her purse but instead of breaking it over Auntie's head, Consuelo lit a flame beneath the egg before blowing the smoke away from Mei Lu. Consuelo asked as to form a circle around the bed and hold hands. She went into a deep trance and began shaking mildly, then violently until nearly stumbling from sheer exhaustion. Consuelo dropped down the chair and turned to Manuel. "She will be 
alright," she whispered. "Your mother will live." We all stood about flabbergasted for around five minutes before the green pulse on Mei Lu's ECG monitor started going berserk. Mei Lu began to stir and we were all agog. "Call the nurses... the doctors..."

195 "No," Consuelo ordered and we all fell silent. "Water," someone croaked in Chinese, and we all turned to Mei Lu and saw her open her eyes like one awakened from the dead. "Water..." she repeated. "Mother..." Manuel cried and hugged his shrunken mother so tightly I thought she would snap in half. We all milled around Mei Lu as Mother brought the plastic straw to my aunt's lips for her to suck some liquid from the beaker. Consuelo took Mei Lu's hand and smiled grandly. She whispered something in Spanish which I failed to catch as my aunt stared blankly at her. "Where am I?" Mei Lu asked in Chinese. "What happened?" Consuelo squeezed her hand. "You will live." And ordered the rest of us to vacate the premises. "You all leave." She commanded and we were all suddenly subject to her mercy and power.

196 Around fifteen minutes later Consuelo alighted from the ICCU as stoic and expressionless as when she arrived at the hospital and proceeded to march down the hallway. Manuel and I ran after her. Manuel vainly tried to catch her attention as Consuelo pushed her way through the glass doors and Manuel followed her in the dark. I rushed back to the ICCU and saw Mother standing distraught at the glass window. Aunt Mei Lu was now conscious and seeing no more visitors.

197 Mei Lu insisted Mother and I brought her home the next day and so we did. She recovered fast during the next few days but remained tight lipped about what transpired between her and Consuelo inside the ICCU even as my cousin disappeared days after they rushed out of the hospital. Mei $\mathrm{Lu}$ appeared unperturbed about her missing son and daughter-in-law. She was a changed woman - silent, composed and reflective - and wouldn't be coaxed into commenting much on anything except to say now and then that most things were so because of "God's will". Manuel had been halfway around the world she said confidently on the fifth day of their disappearance, thought of calling the police but I wasn't certain 
of what to say or how to explain why I was harboring travelers with fake documents. Leaking the story to media might only exacerbate the situation and cause Mei Lu a fatal attack. Sam, on her part, had returned to Davao.

198 Just when I had resolved to drop the whole thing and treat the entire episode as a pleasant, if ill-conceived, joke, Manuel showed up in Aunt Mei Lu's apartment bearing a brass urn. He looked dishelmed and dead tired.

199 “What happened? Where's Consuelo?” I asked.

200 Mother who had now moved in with Mei Lu and reassigned me back to our home, had gone out for groceries with the house help and left me to oversee the place as Mei Lu spend most of the days inside her bedroom.

201 "Here," Manuel said placing the urn on the table.

202 "What do you mean?" I asked, opening the lid and finding nearly a kilo of ashes. "These are ashes," I said and Manuel nodded sadly. "What are you saying Manuel? What happened?” I was frantic.

203 “Consuelo's dead," he murmured. "I mean... departed."

204 "What are you saying? Make up your mind."

205 "Her physical body couldn't stand the strain,"

206 "Strain?"

207 "It took a lot from her... saving Mother... her body gave way."

208 "She died?"

209 Manuel fell silent and looked away. He looked terribly old all of a sudden. It happened that Consuelo asked to be taken to Corrales after reviving Mei Lu at the hospital, she was weak and experiencing palpitations and refused to see a doctor. Corrales brought her to Pampanga for "recharging" by a local psychic healer who was able to stabilize her condition... but after three days, Consuelo suffered a fatal cardiac arrest. Manuel decided not to report the incident to avoid complications, and following Consuelo's village ways, cremated her corpse in a funeral pyre.

210 Manuel's tale left me stoned. Meanwhile, Mother had returned and Mei $\mathrm{Lu}$ had come out to greet her son. Mother could only shake her head 
even as Mei Lu looked truly downcast. "You were not meant to be," she sighed.

211 Something steely ripped through my abdomen. "She saved your life," I said.

212 "Shut up, Carlos," Mother shouted. "This is none of your business."

213 "She saved your life. She died in saving you like a true filial daughter and this is all you say?"

214 Mother was too shocked to utter a word and for a while I thought she'd be the next cardiac victim. Mei Lu stared at me and I could suddenly see Consuelo's deep black onyx eyeballs sizing me up, looking through me. Tearing me apart with their invisible strength. I looked away.

215 Mei Lu approached the table picked up the urn and placed it on the altar beside the portrait of her dead husband. She lighted joss sticks, kowtowed three times before the altar, closed her eyes and prayed fervently, placed the joss sticks on the incense burner before tuning harshly on Manuel. "Manuel," she said, "have you forgotten your ways? You have not once paid respects to your father since coming home.” And suddenly cousin Manuel, weather-beaten and crippled, fell on his knees, touched his forehead to the floor and wept like a child.

216 "Leave us," Mei Lu said. "We are in mourning."

217 A few days later Manuel called up to ask me to drove him to the airport. He had placed some of Consuelo's ashes inside a pouch to be brought back to where they would allegedly provide power to other healers. Meanwhile, the urn would remain in its honored place at the family altar. So much and transpired since the couple arrived and we were silent most of the way.

218 “So, what are your plans?" I finally asked.

219 "I don't know," he sighed. "I know I have to make it up to Consuelo's people. I took her away from them. I have to give back some of myself."

220 "What can you do for them?" I blurted, "with generals and dope dealers on your tail..." 
221 "I have to do some good with that remains of my life, Carlos," he said. "And don't think I can do any of that here. If I can anyone... if I belong to any people, it's to them, the Amazon."

222 "Well, good luck."

223 “There's this environmentalist group trying to stop illegal logging in the rainforests. Perhaps I'll join them.”

224 "Is that what Consuelo would have wanted?"

225 "Consuelo never asked anything of anyone," he whispered. "Yes," he went on. "I'd like to think it's what she would have wanted of me. She loved the forests.

226 "What do you think the talked about?" I asked. "Consuelo and your mother. What do you think they said to know either inside the ICCU?”

227 "Who knows?" he whispered. "I don't think I ever got to know either of them all that well."

228 "Maybe they didn't know you, too." I said. "Maybe you never give anyone enough time to know you."

229 “Maybe they didn't say anything to each other," he said. "Perhaps," I said. "maybe they just needed some time together."

230 "I'm sorry about you and your mother," he whispered. "You've been fighting because of me."

231 "Oh? Not really," I said. "We fight every other week. We're that way most of the time since Father died," And I suddenly remembered cousin Manuel weeping on the floor and wanting to do the same. "It's never really serious. It keeps us talking to each other, at least."

232 "Look after my mother for me," he said as we reached the airport and shook hands. His grip was just as powerful as when he arrived but gone the flourish and the verve

233 "Sure thing." I said. "Take care."

234 "Check up on my sister, too, now and then," he whispered, "she turned out all right, at least."

235 "Sure thing," I said and waited for to limp his way to the departure area. I knew it would be the last I'd see of my cousin Manuel. 
236 To this day I harbor doubts about Manuel's tale about what happened to Consuelo. Months after he left were reports about a "black widow" in Jolo who could cure any ailment, perform fantastic feats, and speak in various tongues. I never checked out the story and she has since supposedly moved to Malaysia. On the first anniversary of their arrival in Manila, I received a postcard from Rio signed Manuel and Consuelo. So she was really alive? Or her spirit transferred to another body? Was this another black healer my cousin has shacked up with or the Sonia Bragg-look-alike of my dreams?

237 I'd probably never know just as I'd never know the whole truth about my cousin Manuel-did he really become an environmentalist or was he back to managing physics? Or what my Aunt Mei Lu and cousin Consuelo said to each other in their fifteen minutes of togetherness. But I know these things shouldn't be bothering me as I sit here in the veranda of our modest beach house in Bauang, La Union rocking our eight month-old Consuelo to sleep in her rattan cradle, watching Samantha and Nic-nic chase frisbees in the sand. Little Consuelo, who has Sam's thin lips and squash seed eyes, points at something in the early evening sky. I look up thinking she's discovered another constellation and know at last that my life will never be the same because once upon a humid dry season, my long lost cousin Manuel, beaten but unbowed, charmed by fate and chased by crooks, hitched his tail to a black star and brought home a wife.

(Ong 96-126)

\section{Guide Questions:}

1. In the story, Manuel had the nickname Ah Siao ("The Crazed One") while Carlos had that of Ah Puy ("Fatty"). These nicknames are typically Chinese in the sense that only Chinese parents would deliberately call their children unflattering names. This stems from an old belief that spirits are just waiting to snatch the children away and therefore, a child 
with such an ugly name would probably be spared by such spirits. This vigilance against these spirits is such that some very traditional Chinese deliberately dress up their sons as girls in their young age to fool these spirits regarding their sex (even the spirits prefer boys!); they also loudly enumerate and lament their children's shortcomings to drive away the spirits. As their children grow older, these unflattering names inevitably stick as their pet names. Comment on this practice vis-à-vis what you know about psychology and Filipino children.

2. Generally, the Chinese do not show their affection publicly. Even parents do not show their love for their children for others to see. Cite how the Chinese show their affection based on the story and your own observations or experiences of such demonstration.

3. One of the conflicts in the story is Mei Lu's inability to accept Consuelo as a daughter-in-law. What is Mei Lu's objection to Consuelo? Do you think she would feel differently if Consuelo were white Brazilian? Note the Chinese's preference for the sons and the lines following from the text: "The woman failed to strike me as being in the universe or from an age where the word beauty conjured in fairness often described as "being edible" and where petite, teen-age, virgin brides were tucked neatly in fragile sedan chairs fit for babies." (par.27)

4. Why do you think the Chinese prefer a Chinese daughter-in-law? What unique roles and duties do a Chinese daughter-in-law have to fulfil for the mother-in-law and the rest of the clan?

5. Although criticism and jokes about the mother-in-law abound all cultures, the Chinese mother-in-law is especially notorious. Why? Discuss the reasons for the antagonism between the mother-in-law and the daughter-in-law in a Chinese family. Would a non-Chinese fare better as a daughter-in-law? Why or why not?

6. Carlos is a grown man yet he is a little boy all over again in the company of his aunt and mother. (Note par. 29 and par. 32.) Why? What "power" does the mother, especially a matriarch, wield in a Chinese family?

7. Samantha's marriage to an older man when she was barely 15 years old (just to avoid Carlos) illustrates the extent to which the Chinese are 
willing to go to save face and avoid a scandal. No matter if the two weren't even blood relatives (Carlos' father being adopted), Mei Lu's decision to have her married off is regarded as a wise decision since people with the same surname aren't supposed to marry each other. Cite the advantages and disadvantages of strict adherence to tradition. Cite Filipino beliefs about marriage which are similar or related to the story.

8. Mei Lu's attack and Consuelo's role in the event ushered the resolution of the conflict; it resulted in the reconciliation between mother and son after twenty years. Regardless of whether Consuelo actually died or not, cite and explain the reasons and events that prompted Mei Lu's change of heart.

9. Mei Lu's acceptance of Consuelo came when she placed the urn supposedly carrying her ashes on the place of honor - beside her husband's picture. Her doing so shows that Consuelo has rightfully earned her place in the clan by being a filial daughter-in-law who serves her mother-in-law unconditionally. Discuss this act in terms of how the Chinese regard the afterlife. Was Mei Lu's act too late? Explain fully.

10. How different or alike is a Chinese matriarch with her Filipino counterpart? Discuss their roles in their respective families and cite how their clans, in turn, regard them. 


\section{"Mother Tongue"}

by Ma. Fatima Lim-Wilson

Ma. Fatima Lim-Wilson graduated from Ateneo de Manila University with an A.B. in English Literature, cum laude and took her Master of Arts in Creative Writing at the State University of New York in Buffalo. She was a fellow in the U.P. National Writers' Workshop in 1986. In 1988, she was a recipient of a summer scholarship at the University of Vienna and toured China as a member of a delegation of poets from the Writers'Union of the Philippines.

Mother, I shadowed by your words

Repeating them at the oddest turns

Before your startled visitors

And the invisible friends

I gathered at about me at dusk.

Mother, as you minced vegetables

Into mosaics, or closed the gaping

Holes of my skirt, you murmured:

"Lucillulilla... Rorobarodo... Mulamuna..."

My dolls moved their lips with yours.

Mother, alone in Formosa,

You found your way home.

I felt your tongue pressed my ear.

Walking to an empty house, I ran to your room

Where we whispered through a cracked mirror.

Mother, when did I unlearn to speak

I can no longer hear you, not even in sleep.

Scanning mirrors, I catch shadows.

I can only smile at myself now. 


\section{Guide Questions:}

1. Describe the mother and the speaker. Are they the typical Chinese wife and daughter?

2. Nowadays, one of the "most important" considerations for taking a prospective Chinese-Filipino daughter-in-law is her ability to speak Chinese. In the poem, is the persona still able to speak Chinese? Does this pose a great problem to her? Explain fully.

3. Why do you suppose the Chinese place a great value on the ability to speak the mother tongue? Explain why this is still important for Chinese-Filipinos who were born and have lived here all their lives.

4. Second-generation Filipino-Americans who cannot speak Filipino but can speak fluent English are not considered an embarrassment to their families. Chinese-Filipinos, on the other hand, are considered shameful if they cannot speak Chinese even if they speak fluent Filipino and English. What problems do you foresee for a Chinese-Filipino daughter or wife who cannot speak Chinese? Is this inability to speak the mother tongue enough for the family "to lose face"? 


\section{“Upon My Father's Calligraphy"}

by Ma. Fatima Lim

White, cold sheets

Whiter, and colder than the marble of your tomb.

My warm fingers rub them back and forth,

Up and down,

My life trying to bring to life

The beautiful black lines

Brooding in the paper-thin silence

I cannot understand.

Father, why is it you never told me

That you wrote

In a private office room of your misery?

'I am a cup

Precious to the eye

Put behind glass

Because I am ancient

And cracked.'

My uncle tells me that is what you say.

I must believe him.

Then I will never know for myself

Your fears for yourself

And for your youngest child:

The frail, brown bird

Who chattered in that singsong English

You could hardly follow

And who grew frightened

With your unsure grasp.

I thought you would snatch from me the air

That you had given

And so I flew away. 
And now it is I who come back

Unsure,

Holding close to your poems

Hoping to find in them

What I want to believe

You would have wished for me

'I am a cup...'

You never held me to your lips

'Precious to the eye ...'

And I look up to you

'Put behind glass...'

And now this impenetrable permanence

'Because I am ancient...'

And today I am young

'And cracked.'

Something in me melts

As I watch the beautiful black lines blur.

I let go

Watching as you must have,

Your pet doves exulting in the air.

(Lim, Wandering Roots, 1-2) 


\section{Guide Questions:}

1. Calligraphy is the fine art of penmanship that uses a special pen or brush. Chinese calligraphy using a Chinese brush and ink takes years of meticulous practice before one can be considered an expert in it. Discuss what the father's calligraphy reveals to the speaker.

2. Describe the effect of the father's words on the persona. Does the calligraphy's message come as a surprise? Why or why not?

3. As gleaned from the poem, how can the father's relationship with the persona be described? List and discuss the possible reasons for such a relationship.

4. Explain how the speaker's ability to speak Chinese would have helped the father-daughter relationship. 


\section{"Father, in Old Town, Stockholm"}

by Ma. Fatima Lim-Wilson

Why is it not at all strange

That I should find you here, Father?

Even the young Swede

Ringing the bell of his bicycle

And the bent, bandannaed kvinna

Moving her cane to make room for you

Do not stop in their tracks

On the cobblestones to ponder,

'Why is this man

Dead almost ten years now

Strolling like a native

Down our twisted streets of Old Town?'

You are looking happier than I remember.

Pants of loose silk, hair in a queue,

You smile at the blonde infants in their prams

And stop for what seems to be too long for a while

Before figurines of Scandinavian crystals.

Slowly, I walk up from behind you

Unafraid to admit only now:

'Yes, the glass is lovely,

Only because you do not seem to judge them frail.'

You do not see me. You walk on

Towards where Lake Malar reaches the Baltic,

Taking a boat from this strand to Drottingholm

Where Tessin the Younger built a palace

For his bride in Chinoiserie.

I will not follow you, ask you to come back with me

Or at least let you know why I am here.

Go home, Father, undo the redolent fir

Where winter falls in thick patches 
And the midnight sun casts shadows over stars.

Your home is in the China Palace, Father,

Centuries old and empty,

Where your children cannot ask you

In what strange tongue you speak in your sleep.

(Lim, Wandering Roots 3)

\section{Guide Questions:}

1. Communication gap between parents and children in a Chinese-Filipino family is common. Considering the undemonstrative style of parenting the older generation Chinese received and the increasing influence of the West on the younger ones (with its emphasis on individual rights, freedom of speech, and others) what other problems can you surmise the father and the speaker in the poem had?

2. Would the speaker's ability to speak Chinese have helped the two? Why or why not?

3. Trace the reasons for the gap between the older Chinese and the young Chinese-Filipinos of today.

4. What is the rationale behind the undemonstrative way by the older Chinese in dealing with their children? Are these reasons still applicable in the MTV generation of today? Explain fully.

5. Describe the speaker as she reveals herself in the following lines:

slowly, I walk up from behind you

Unafraid to admit only now:

'yes, the glass is lovely,

Only because you do not seem to judge them frail.' (lines 18-21)

Would you say that this character is typical of Chinese girls? Why or why not? 


\section{"Ming Tombs"}

by Ma. Fatima Lim-Wilson

Perhaps it began in childhood

When I thought it best to leave

Some things misunderstood:

Why a cousin, twice removed

Would lay a bowl of fruit

Before a dead man's picture

Or why, while still fast asleep

In her pram, her parents already planned

Her future with an infant bridegroom.

Perhaps the slightest resentment

Built brick by brick

Against those who marked me

By my single-syllabled name:

Thrusting me amongst the tightly-knit

Tight-fisted clan whose speech

Clanged in the ears and who,

In supposed greed,

Hoarded gold in the holes

Of their teeth.

(And yet I had no claims

To the inner circle, having lost father

My key, for far too many years.)

Perhaps all this no longer matter now

Here, in the underground kingdom

Northeast of China, where I find

Myself with father, familiarly floating

With or royal kin. We trail

Dragon's Breath and silken wings 
While the rabble of tourists

Toddle below, staring disappointedly

At the empty tombs.

(Lim, Wandering Roots 4)

\section{Guide Questions:}

1. Filial piety has been unquestionably the moral barometer of the Chinese for thousands of years. An important aspect of it demanded the observation of proper rites of ancestor worship for one's kin. The birth of a son is viewed as an extremely important and fortunate event as it assured the perpetuation of the clan the proper observance of ancestor worship. Discuss the advantages and disadvantages of ancestor worship (including the regard for sons) in this day and age.

2. Part of the rituals observed in ancestral worship includes offering of food, lighting of joss sticks, and burning of spirit money before a portrait of the dead. Does the Filipino culture have a similar practice regarding their dead? Explain fully.

3. Discuss how Filipino and Chinese parents differ in their treatment of their sons and daughters.

4. Traditionally, Chinese parents arranged the marriages of their children. Discuss the advantages and disadvantages of this practice today.

5. Explain the speaker's resentment and alienation. In general, is this situation typical or atypical of Chinese-Filipino women? 
"Chinatown"

by Ma. Fatima Lim-Wilson

Suddenly, I desire

These narrow streets.

The clanging din

Of a different tongue

Lighting needles

Puncturing my ribs.

And the drink

Brewed from the root

Twisted into a man.

If only Father lived.

He would read my future

Unfurling in the tea leaves,

Show me the inn

Where they serve

The finest jumping shrimps,

And lead the way to the old pagoda

Where a long-lost uncle lives.

As they trade

Old tales. Father slips

A band of heavy jade

Upon my wrist.

A stone dragon leaps.

I am borne, a quarter-moon-

Eye child, home, upon

My father's shimmering

Back. 


\section{Guide Questions:}

1. Describe Chinatown in the poem and in the different Chinatowns you may have visited or heard about. What are some sights unique only to this place? Would a Filipino feel at home here? How about the ChineseFilipino? Explain fully.

2. What does the persona feel as she visits the place? Would you say that the feeling is common to the young Chinese-Filipino (even if unlike in the poem, the parents are alive)? Why or why not? 


\section{"Frost's Cabin" \\ by Ma. Fatima Lim}

(Middleburry, Vermont)

For Marian Yee

It won't be long now

Our manuscripts, thin and mute

Will flower in print,

Magnifying by word of mouth.

In Manila, my mother in the market place

Tears passages of my poems,

Bandages to lay across murdered men's eyes.

In Foochow, your relatives hearing of you,

Write and make themselves known.

They promise never again

To leave a girl exposed on a hill

Here, the blue grass crashes like waves

With wind and cricket sound.

Their crested blades slash our chins

Our breasts tingle in the late summer dusk.

We stand still, before the cabin

'Here is where Robert Frost wrote.'

The shut window offers a dim view.

A fireplace. Dried flowers in a vase.

Soft Slippers under a bed. An Inkwell.

Soon! All this will happen to us soon.

We leave finger smudges on the glass. 
We cup our voices,

Shouting our unknown names to the green hills.

(Wandering Roots 32)

\section{Guide Questions:}

1. Describe how the relatives of the persona and the "you" might react to the speaker's success as a writer. Do you think their reactions would come as a surprise? Why or why not?

2. Why would the mother use the poems to bandage the eyes of murdered men in Manila? Does this image support or overlook the speaker's success? Explain fully.

3. Explain stanza 3. Why would the relatives in Foochow "make themselves known" (line 9)? Is this uncommon or suspect? Why or why not?

4. What is the reference to leaving girls exposed on the hill? Is this practice peculiar only to the people of Foochow? What are the underlying reasons for such a practice?

5. Cite reasons why many committed female infanticide and discuss whether these justify the parents' decision. Take into account that Foochow is located in barren Fujian Province where majority of the people are impoverished. 


\section{APPENDIX 1}

\section{The Lesson Plans: A Teacher's Guide}

This Reader aims to present the unique role of women among ChineseFilipinos through selected short stories and poems; at the same time, it offers 4 sample lesson plans to help non-Chinese teachers tackle such literary texts in the classroom. The sample lesson plans employ teaching techniques which offer teacher and student alternative activities in the classroom. 


\section{Lesson Plan A: “Anais” by Doreen Yu}

Methods: Interactive Text Processing, Gradual Psychological Unfolding, Cooperative Learning

Lessons may take two to three 40 -minute sessions.

I. Objectives

1. To infer mood, tone, emotional reactions, motivations, and traits of characters.

2. To extract the theme and/or significant human experience.

3. To cite and discuss the different cultural values in the story.

4. To share ideas, feelings, experiences about and in relation to the story.

5. To gain a better understanding of the Filipino-Chinese culture as seen in students' views.

\section{Procedure: Interactive Text Processing}

A. Check-up Quiz: Bottom-up Text Processing

1. How did Dina learn of Ainee's death?

2. Where is the story set?

3. How did Ainee die?

4. What was she sick of?

5. Who told Dina about Ainee's sickness?

B. Motivation: Top-Down Text Processing:

(As an assignment, the class has previously been asked to read about different Filipino customs and practices about death.)

Discuss and describe the different Filipino practices, beliefs, and rituals about death you know. How are these practices similar with or different from the Chinese practices we see in the story?

In a Chinese-Filipino wake, one would see burning incense, food offerings, banners of white with Chinese characters written 
in black ink offering condolences, mourners and visitors dressed in black or white and paper money for the dead being folded and burnt as offering, as the story showed. Ainee was a baptized Christian yet her mother preferred that they follow all the Buddhist funeral customs. What does this reveal about Ainee's family? How does this pose as a problem?

C. Motive question in relation to the story: Bottom-up text processing

Dina attended her friend Ainee's wake. Why did she feel uneasy? Cite proofs from the text.

D. Questions for discussion: Gradual Psychological Unfolding

1. Who is the speaker? How is she related to Ainee? What role will she play in Ainee's problem?

2. What is the conflict in the story?

3. Based on what you know about Ainee's childhood and family background, trace the possible causes of Ainee's problem with her family.

4. Do you agree with Ainee's view that exclusive schools area "cloistered and stifling institutions of non-learning?" (par. 10) Why/why not?

5. Why do you suppose she said that?

6. Would Ainee's life have been different if her parents simply had her treated in Manila? Why or why not?

7. What do you think is the author saying about "absurd deaths and stifled minds"? (par 23)

8. Explain why you agree or disagree with the author (in relation with no. 7)

9. Do you know anyone like Ainee or her parents? Describe them briefly.

10. How would you counsel Ainee if she were to come to you for help or advice? 
11. To what extent is society and Ainee herself responsible for her situation?

12. Obviously, Ainee is a tragic figure, alone and alienated from her community. List all the possible causes of her alienation and give corresponding solutions.

13. As the story progresses, who gets more of your sympathy, Ainee or her parents? Can you blame her or them? Why or why not?

14. In a traditional Chinese-Filipino family, daughters do not enjoy the same status as sons. Most of their decisions on choice of university, course, career, and eventually even of a husband usually depend on what their parents say. Discuss how this practice contributed to the conflict of the story.

15. In ancient China, women were regarded as inferior to men and subject to the three obediences; in childhood, subject to her father or elder brother; in marriage, to her husband, in old age, to her son. Although women are generally better off today (they are not sold as slaves or put to death merely on account of their sex), they are still not equal to the male. Chinese-Filipinos are generally traditional and patriarchal. Discuss how this situation can cause problems to a modern Chinese-Filipino woman like Ainee educated in western ways.

E. Class Activity

\section{OPTION 1: Collaborative Learning and Writing}

Divide the class into groups of 5 . Name the groups $A, B, C, D$, and E. Ask each group to write a dialogue for the characters in the situation that will be assigned to them. They are free to add details and be as dramatic as they please as long as these details will not go against the plot of the text. They must guard against stereotyping the characters into good or bad guys. (The teacher should type each situation on a strip of paper before class to save time.) 


\begin{tabular}{|c|l|}
\hline Group & \multicolumn{1}{|c|}{ Situation } \\
\hline A & $\begin{array}{l}\text { Ainee talks to George about her situation. She wants to keep her } \\
\text { illness a secret from her parents; George is optimistic that her } \\
\text { parents will understand. He is encouraging and supportive. }\end{array}$ \\
\hline B & $\begin{array}{l}\text { Ainee tells her parents about her addiction and illness. They are } \\
\text { shocked and hurt. They insist that she goes to the US for treat- } \\
\text { ment but she is equally adamant against the idea. }\end{array}$ \\
\hline C & $\begin{array}{l}\text { Ainee leaves home as her parents and siblings talk about what to } \\
\text { do. They discuss how to avoid losing face and how to best con- } \\
\text { vince Ainee to come home and seek treatment abroad. They love } \\
\text { her but do not know how to deal with her. Finally, they ask Lily to } \\
\text { talk to Ainee. }\end{array}$ \\
\hline D & $\begin{array}{l}\text { Ainee refuses to see Lily. Lily asks Ainee's friends to convince Ain- } \\
\text { ee to come home or to talk to her. When Lily leaves, Ainee talks } \\
\text { to her friends about her problems with her family. }\end{array}$ \\
\hline E & $\begin{array}{l}\text { Ainee's father, mother, and siblings receive a phone call informing } \\
\text { them of her accident. They are shocked, dismayed, and distraught. } \\
\text { Include in your dialogue a lamentation about missed opportunities } \\
\text { and wasted lives, about the trap between what tradition demands } \\
\text { and what they feel should be done nowadays. }\end{array}$ \\
\hline
\end{tabular}

Ask students to rehearse the dialogue they have written and to present it in a dramatic fashion to the class in the next meeting.

\section{OPTION 2: Round Table}

Conduct a discussion on the very Asian value of "saving face." When can this practice be advantageous and disadvantageous? In a Chinese-Filipino community, does this practice help bring about order, unity, and understanding? Or is it actually divisive which leads to more problems? Does the same situation exist in a Filipino community? Would it be the same in Japan or Korea? How is it the same or different? Make sure the class can cite concrete examples or proofs to support their answers. 


\section{Closure and Assignments}

Ask the students to read "The Burial" by Benito Lim. What similarities and differences regarding the conflict of traditions do the stories show? Are there more examples of "absurd death and stifled minds" here? Complete the Venn diagram by listing the similarities and differences regarding the conflict of traditions in "The Burial" and in "Anais."

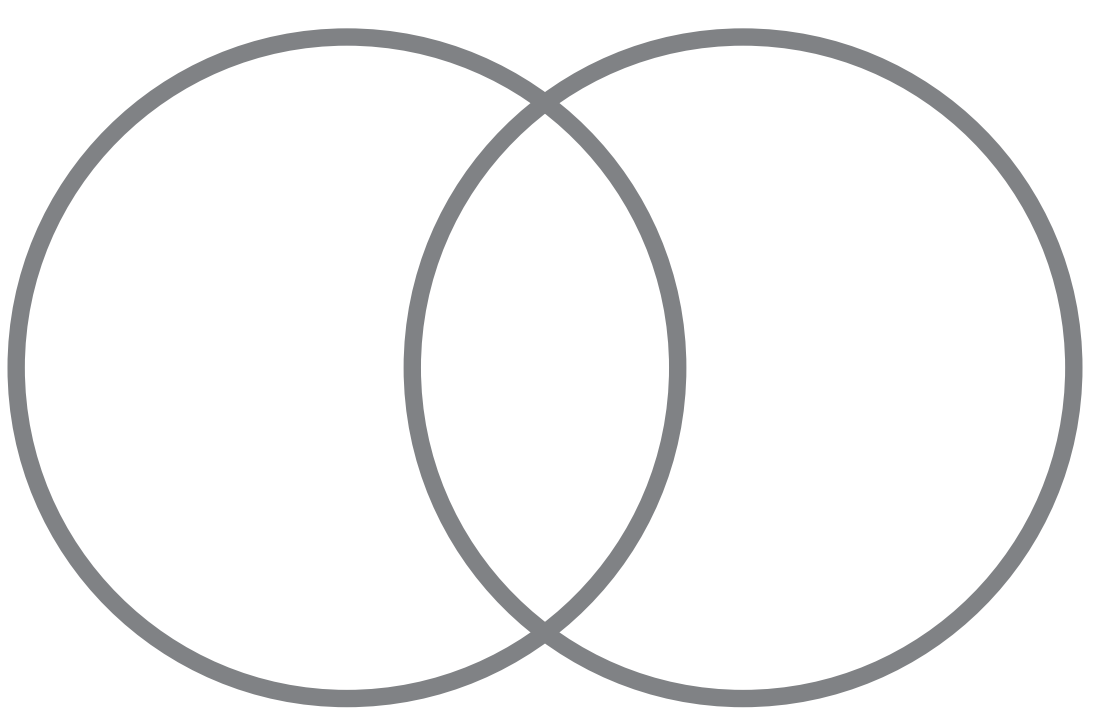




\title{
Lesson Plan B: "Trouble in Beijing" by Charlson Ong
}

\author{
Method: Howard Gardner's Seven Intelligences
}

\section{Objectives}

1. To write ideas, perceptions, and feelings about the Chinese as they listen to a Chinese song (based on this strategy, the music will simply be playing in the background. It does not matter if they understand Chinese or not).

2. To define unfamiliar words through context clues.

3. To discuss the elements of fiction with a partner or a group.

4. To show an increasing awareness of the Chinese-Filipino way of life as seen in their answers.

\section{Procedure}

Howard Gardner's strategy hopes to tap the seven intelligences of students. Depending on a teacher's class make up, the teacher may use all 7 intelligences to cater to all groups of learners or choose to concentrate on those that have the most students.

The following may be done in any order, depending on the class.

\begin{tabular}{|l|l|l|}
\hline (Motivation) & $\begin{array}{l}\text { Musical Intrapersonal } \\
\text { self-knowledge (draw- } \\
\text { ing on experiences and } \\
\text { observations) }\end{array}$ & $\begin{array}{l}\text { Let the students listen to a Chinese } \\
\text { song. (As they listen, they should list } \\
\text { down everything they know about } \\
\text { Chinese customs, vices, virtues, } \\
\text { and others. Encourage them to } \\
\text { write these in complete sentences. } \\
\text { (Non-Chinese students like Chi- } \\
\text { nese-Filipino students will just listen } \\
\text { to the music as background music. } \\
\text { They do not need to understand the } \\
\text { lyrics.) }\end{array}$ \\
\hline
\end{tabular}




\begin{tabular}{|c|c|c|}
\hline \multirow[t]{3}{*}{$\begin{array}{l}\text { (From Peer to } \\
\text { Group Work) }\end{array}$} & $\begin{array}{l}\text { 2. Interpersonal Lin- } \\
\text { guistic }\end{array}$ & $\begin{array}{l}\text { Let them share what they wrote with } \\
\text { their partner. Volunteer pairs may } \\
\text { then read their list to the class. }\end{array}$ \\
\hline & $\begin{array}{l}\text { 3. Linguistic (expanding } \\
\text { concepts and vocab- } \\
\text { ulary) }\end{array}$ & $\begin{array}{l}\text { Write the following words on the } \\
\text { board (the numbers are paragraph } \\
\text { numbers): } \\
\text { Reluctant (1) } \\
\text { Exhilarated (2) } \\
\text { Trepidation (2) } \\
\text { Uncanny (7) } \\
\text { Exasperation (12) } \\
\text { Malignant (14) } \\
\text { Progeny (18) } \\
\text { Irrepressible (19) } \\
\text { Paradigm (94) } \\
\text { Elicit meanings through context clues } \\
\text { and examples. }\end{array}$ \\
\hline & $\begin{array}{l}\text { 4. Interpersonal Cooper- } \\
\text { ative Reading Bodily- } \\
\text { Kinesthetic }\end{array}$ & $\begin{array}{l}\text { Let them read the selection in groups } \\
\text { of five. When they are done, let them } \\
\text { discuss the following: } \\
\text { a. What is the conflict in the } \\
\text { b. How is the Tiananmen } \\
\text { conflict related to the } \\
\text { c. How was the conflict } \\
\text { resolved? } \\
\text { Present a short skit of a,b,c. }\end{array}$ \\
\hline & $\begin{array}{l}\text { 5. Logical Mathematics } \\
\text { Linguistic }\end{array}$ & $\begin{array}{l}\text { How many conflicts had to be re- } \\
\text { solved in the story? Summarize each } \\
\text { conflict. } \\
\text { How many stages do the story go } \\
\text { through? Summarize these stages. }\end{array}$ \\
\hline & $\begin{array}{l}\text { 6. Interpersonal Bodily } \\
\text { (kinesthetic) }\end{array}$ & $\begin{array}{l}\text { Have students role-play the high- } \\
\text { lights of these steps. }\end{array}$ \\
\hline & $\begin{array}{l}\text { 7. Interpersonal Af- } \\
\text { fective (emotional } \\
\text { response) }\end{array}$ & $\begin{array}{l}\text { Encourage them to analyze their re- } \\
\text { actions to the story as the characters } \\
\text { are slowly revealed. What different } \\
\text { stages did the characters go through } \\
\text { themselves adjusting through the } \\
\text { development of the story? }\end{array}$ \\
\hline
\end{tabular}




\begin{tabular}{|c|c|c|}
\hline & $\begin{array}{l}\text { Linguistic Intraperson- } \\
\text { al Spatial-Visual }\end{array}$ & $\begin{array}{l}\text { Ask them to graph the story struc- } \\
\text { ture. Where would they place the } \\
\text { climax, the turning point of the } \\
\text { story? Ask them whether they found } \\
\text { the ending predictable or credible. }\end{array}$ \\
\hline & $\begin{array}{l}\text { Linguistic Critical } \\
\text { Thinking }\end{array}$ & $\begin{array}{l}\text { Based on the story, the Chinese-Fil- } \\
\text { ipino woman is caught between the } \\
\text { western-influenced education she has } \\
\text { received and her family's adherence } \\
\text { to traditional ways and beliefs. One } \\
\text { example a conservative Chinese still } \\
\text { have would be "girl's do not count." } \\
\text { Ask the class how this view can be } \\
\text { the cause of discord in the family } \\
\text { and the community as a whole. They } \\
\text { must take into account the Chinese } \\
\text { value of filial piety. }\end{array}$ \\
\hline & $\begin{array}{l}\text { From Reading to } \\
\text { Writing Linguistic } \\
\text { Spatial-Visual }\end{array}$ & $\begin{array}{l}\text { Discuss characterization as an } \\
\text { element of fiction by examining the } \\
\text { following statements: } \\
\text { a. Characters are revealed as } \\
\text { the story unfolds. } \\
\text { b. Authors use dialogue to } \\
\text { reveal character traits } \\
\text { (both through the charac- } \\
\text { ters' words and what other } \\
\text { characters say about them). } \\
\text { c. Authors use narration, } \\
\text { description, and exposition } \\
\text { to describe characters' } \\
\text { thoughts, feelings, and } \\
\text { actions. } \\
\text { d. How the main characters } \\
\text { deal with the conflict in the } \\
\text { story reveals the protago- } \\
\text { nist's character. }\end{array}$ \\
\hline
\end{tabular}


III. Closure and Assignment: Ask students to work in pairs to complete the table below.

\section{Simone's Character Development}

\begin{tabular}{|l|l|l|}
\hline As a daughter & As Larry's girlfriend & As herself \\
\hline & & \\
\hline & & \\
\hline & & \\
\hline & & \\
\hline
\end{tabular}




\section{Lesson Plan C: “Ming Tombs” by Ma. Fatima Lim-Wilson}

Reading and Interpreting Poetry

Method: Directed Reading and Thinking Activity

Lesson may take two 40-minute sessions

I. Objectives

1. To read and interpret a poem

2. To answer discussion questions

3. To gain a deeper understanding of the Chinese-Filipinos as seen in their views.

II. Procedure

A. Reading a Poem

The class (through choral reading), and finally, a student.

B. Discussion: Pair Work

1. Which of the following statements are true? Be prepared to defend your answer.

a. The persona resented being Chinese.

b. The persona felt being alienated from the Chinese community.

c. The persona understood and approved of the traditional. Chinese customs of offering food for the dead and arranged marriage.

d. The father was regarded as the link to the Chinese.

e. The persona blames the father for his or her alienation.

2. The speaker's tone of voice is
a. bitter
d. matter-of-fact
g. sarcastic
b. reflective
e. resigned
c. sad
f. nostalgic 
3. Opening each stanza with the word "perhaps" shows. (Choose one and defend it.)

a. the writer's inability to nail down the specific reason for the person's feelings;

b. the vacillation of the speaker toward his/her father;

c. the writer's emotive style; or

d. the persona's mood.

C. Reaction Guide

1. Check the statements that "people who marked" the persona guilty might have said:

a. __I wish I had your fair skin.

b. __Remember, children are supposed to be seen not heard.

c. __Her mother must have not taught her any manners. Look how she receives Grandfather's gift with only one hand!

d. __Are you sure you can still see with those eyes?

2. Write 3 more possible statements these people might have said.

3. Which of the following statements related to the poem do you agree with? Explain fully.

a. A bi-cultural identity can lead to alienation from both communities.

b. Traditional customs and beliefs have no place in modern life.

c. Losing a parent can lead to feelings of insecurity and inadequacy.

d. Visiting the place of one's roots would make one extremely nostalgic.

III. Assignment: Read "Chinatown" and compare the feelings expressed by the persona with those expressed in "Ming Tombs." Look into the poems' ideas, attitudes, language, and poetic form. 


\title{
Lesson Plan D: "Upon my Father's Calligraphy” by Ma. Fatima Lim-Wilson
}

\author{
Method: Jigsaw Reading (Cooperative Learning) \\ Lesson may take two 40-minute sessions
}

\section{Objective}

A. To read and interpret a poem

1. Who is the speaker in the poem? Is the speaker a girl or a boy?

2. What has the persona discovered? How does he or she react to this discovery?

3. What is the persona's reason for "trying to bring to life the beautiful black lines" he/she cannot understand?

4. Describe the persona's relationship with the father. Give possible reasons for this kind of relationship.

5. What is the dominant feeling expressed in the father's calligraphy? Cite possible reasons for such a feeling based on the poem and what you know about the parent-daughter relationship of the Chinese.

B. To infer the value of responsibility as individuals belonging to a group as seen in their own dealings with their group.

C. To infer the values of group process shown in their own groups.

D. To gain new insights on Chinese-Filipino family and ties as seen in their answers.

\section{Procedure}

A. After students read the poem aloud by turns, divide the class into groups of six.

B. Before giving instructions, get a representative from each group who will monitor the behavior of his or her group members throughout the activity. They will be using an observation sheet to monitor the group but may still join the discussion. He or she will 
make frequency marks by the category as the members exhibit a behavior. The categories are as follows:

\begin{tabular}{|l|l|l|l|l|l|l|}
\hline \multicolumn{1}{|c|}{ Member } & 1 & 2 & 3 & 4 & 5 & 6 \\
\hline Behavior & & & & & & \\
\hline $\begin{array}{l}\text { Makes sure everyone } \\
\text { understands }\end{array}$ & & & & & & \\
\hline $\begin{array}{l}\text { Encourages others to } \\
\text { contribute }\end{array}$ & & & & & & \\
\hline Expresses feelings & & & & & & \\
\hline $\begin{array}{l}\text { Gives directions on } \\
\text { group work }\end{array}$ & & & & & & \\
\hline
\end{tabular}

The representatives will be asked to report their observations after the discussion; another student will act as a recorder of the group discussion.

C. Explain the learning task. Each student will be assigned a question and will be responsible in answering the said question. After the 5 members have finished answering their respective questions on their own, they will discuss their answers with the other members of the group.

D. Explain the goal structure. Tell the students that they have to work together in answering the questions. They are to turn in one set of answers which reflects the group's consensus. Their signature on the sheets indicates that they agree with and understand the group's answers and the reasons for them. As group members, they are to make sure that everyone has his or her say and that everyone understands. The group's answer will be graded on how well they defend their answers. Logical explanations of answers, those that may be supported by text evidence, will be looked for; points will be taken off for illogical and unfounded arguments or answers which show lack of discussion depth. 
E. Monitor the group sessions, occasionally checking to see if a student can explain an answer the group already agreed upon. Students showing group skills are pointed out and praised.

F. Assess the group task. Each group will be asked to read their answers to the class and other groups offer their comments and reactions. The groups are then asked to check their answers to see if they are satisfied and make changes if they wish to. Papers are then to be submitted for grading.

1. How well did you work as a group? Was it easy to come to an agreement? What happened when members disagreed? How did you persuade each other to agree on something?

2. What would help you work better together? (The observer will act as a resource person for this.)

\section{Assignment}

Through the activity, we saw the importance of communication, which enabled members of a group to share their ideas, feelings, and opinions about something in an atmosphere of openness and respect. In the poem "Upon my Father's Calligraphy," communication was able to proceed smoothly between father and a child.

In a well-developed composition, trace the possible reasons why Chinese-Filipino children would have a greater communication gap with their parents compared to Filipino children. What in their culture, traditions, and beliefs block smooth communication lines between parents and children? 


\section{APPENDIX 2}

\section{Note to the Teacher on the Different Teaching Techniques}

Teachers familiar with theories of teaching will benefit from the sample lesson plans as they integrate concepts and principles into practice that work in the classroom. The teacher can choose the methods and strategies that would best suit his or her students' personalities and abilities. The following notes are intended for teachers who may not be familiar with the technical names of these techniques or teaching theories. It is hoped that reading about these techniques and trying the lesson plans in the classroom will prove to be rewarding for both teacher and student.

\section{Interactive Text Processing}

The interactive model is one model of the reading process that takes place in the reader. In Rumelhart's model, the reader processes factors like letter features and sounds (referred to as bottom-up factors) at the same time as factors like his or her knowledge of the topic of the text and the situation in which it is read (referred to as top-down). This interactive model, therefore, suggests that reading involves a simultaneous parallel processing of both 
bottom-up and top down-down factors. The model proposes that the weight given to particular factors, whether bottom-up or top-down, will depend on the characteristics of the reader (such as decoding ability), the text (such as familiarity of topic), and the context or environment in which reading takes place. Thus, the importance of top-down and bottom-up factors will differ from reader to reader, text to text, and situation to situation.

There are two areas of pedagogy which can assist readers to improve their bottom-up, language decoding skills, grammatical skills, and vocabulary development. The following pre-reading activities can enhance top-down processing: direct teaching through lectures; viewing movies, plays, slides, and pictures; going on field trips, demonstrations, real-life experiences; using text previewing, role-plays, and key-word-concepts association activities.

Moreover, the following organized methods help activate appropriate background knowledge:

1. Language Experience Approach or LEA (Hall, 1981; Rigg, 1981; and Stauffer, 1969)

2. Extending Concepts Through Language Activities or ECOLA (Smith-Burke, 1980)

3. Directed Reading Thinking Activity or DRTA (Stauffer, 1980)

4. Experience-Text-Relationship Method or ETR (Au, 1979)

5. The Pre-Reading Plan or PReP (Langer, 1980)

6. Survey-Question-Read-Recite-Review Method or SQ3R (Robinson, 1946)

\section{Gradual Psychological Unfolding}

An interactive approach to content and formal schemata would result to better learning. Since content schemata is simply background knowledge on a particular subject (tapped widely by the teacher through the motivation question), students presented with questions could easily contribute to the discussion since they need nothing but their own ideas, experiences, opinions, and/or observations to contribute to the discussion. In contrast, classes that use the formal schemata (a type of orientation/presentation of 
text) alone may cover matter more quickly but these tend to be rigid, formal, and limited. One of the interactive approaches is the Gradual Psychological Unfolding approach which tackles both content and formal schemata through a question-answer technique.

This technique requires the teacher to prepare a list of questions which slowly lead students to the focal point of the lesson. These questions are so arranged that a student's response will lead to the teacher's next question. Since both formal and content schemata are used, the class session becomes richer and more meaningful to both teacher and students. Much of student anxiety is limited since everyone gets a chance to contribute answers in the capacity that they are already used to. An illustration of the technique may be shown as:

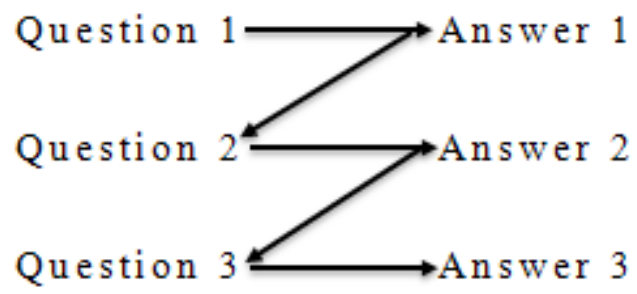

Through this questioning technique, the discussion moves horizontally tapping the learner's background knowledge and vertically eliciting reactions on the entire text.

\section{Directed Reading Thinking Activity (DRTA)}

The Directed Reading Thinking Activity developed by Stauffer (1969) was one of the first techniques that attempted to teach students how to understand what they were reading by encouraging them in the active processing of text. In this technique, the teacher asks questions that encourage students to ask questions and make predictions after reading, and provide support from the text regarding the validity of their predictions. 
DRTA is normally used with a narrative text and is particularly appropriate to use as a during-reading activity when the inferential strategy activity has been used as a pre-reading activity. In using DRTA, the teacher should interrupt the students' reading of the text for discussion at points where the students can make predictions, at points where their predictions are confirmed or refuted by the text, and where students can provide support for this confirmation or refutation.

The teacher asks four kinds of questions basic to the DRTA technique:

1. What do you think a story (or poem) with a title like this might be about?

2. What do you think of it now? (Is your prediction confirmed or refuted?)

3. What in the story makes you think that?

4. What do you think will happen next?

Although this technique may appear traditional in the sense that the teacher still asks the questions, the DRTA remains a valuable technique as it allows the students to think critically and to give intelligent predictions based on the data provided by the text.

\section{Cooperative Learning}

Although some teachers may view group work as the lazy teacher's way to kill time in the classroom, more teachers have discovered the wisdom of grouping students to work together instead of leaving them to compete against one another. Different from the traditional classroom structure where students compete for teacher recognition and grades, the Cooperative Learning technique encourages students to divide the work among themselves, help one another (especially the slow learners), praise, and criticize one another's efforts and contributions, and receive a group performance score. This is not to say that competition has no place in the classroom. Even advocates of the technique feel that competition under the right conditions and with evenly matched competitors can be a source of motivation, fun, excitement, and improved performance. However, compared to traditional 
classes, those that employ cooperative learning show reduced hostility, prejudice, and patterns of failure among many students.

According to a review of research, cooperation among students help build positive and coherent personal identity, self-actualization and mental health, knowledge and trust of others, communication, acceptance, and support of others, wholesome relationships and reduction of conflicts.

Jigsaw classroom or other variants like "jigsaw reading," "jigsaw learning," and others are forms of the cooperative learning approach designed for high school. Here, students work together in small groups on specific tasks and rely on each other for resources and information to present a concrete whole.

The following Guidelines for Cooperative Learning were developed by David and Roger Johnson:

1. Arrange the classroom to promote cooperative goals. Students will need to work in clusters. Seating arrangements should reflect this need and provide sufficient space and study areas for students to share. Position media equipment in a way that students have easy access to them as a group.

2. Present the objectives as group objectives. The group and not the individual is the focus. Gear the reward structure to achieving group objectives.

3. Communicate intentions and expectations. Students need to understand what is being attempted. They should know what to expect from the teacher and from each student in the group and what the teacher expects them to accomplish.

4. Encourage a division of labor. Students should understand their roles and responsibilities.

5. Encourage students to share ideas, materials, and resources. They should look to each other and not the teacher. The teacher may act as catalyst in making suggestions but not be the major source of ideas.

6. Supply a variety of materials. Since the sharing of materials is essential to the group, sufficient quantities and variety are needed. 
If materials are insufficient, the work may bog down and perhaps be disrupted.

7. Encourage students to communicate their ideas clearly. Verbal messages should be clear and concise. Verbal and nonverbal messages should be congruent with each other.

8. Encourage supportive behavior and point out hostile behavior. Behavior such as silence, ridicule, personal criticism, one-upmanship and superficial acceptance of an idea should be discussed and stopped since these hinder cooperation and productive group behavior.

9. Provide appropriate cues and signals. Point out when the noise level is too high ("Things are getting a little too boisterous"). Direct a group's attention to individual problems and encourage students to use the group ("Check with the group"; "Would you please add this problem to the group's agenda?").

10. Monitor the group. Check progress of individuals in a group and of the group as a whole. Explain and discuss problems, assist, and give praise when appropriate.

11. Evaluate the individual and the group. In evaluation, focus on the group and its progress. Evaluate the individual in the context of the group's effort and achievement. Provide prompt feedback.

12. Reward the group for the successful completion of its task. After evaluation, recognition and rewards should be given on a group basis so that individual members come to realize that they benefit from each other's work and will help each other succeed.

\section{The Seven Intelligences}

Since repeated cooperative learning tasks can also prove to be tedious, teachers can rely on other techniques to whip up students' interest, and increase their performance by using the Seven Intelligences.

Howard Gardner contends that there are seven ways of being smartin math or logic, linguistics, spatial sense, the use of the body, music, and interpersonal and intrapersonal relationships-which we use with different 
abilities. Teaching students to recognize how they learn best will help them become adept lifelong learners. Moreover, using all seven types of intelligences is better because more students will learn that way. As classes grow bigger and bigger in size due to certain constraints through the years, teachers who employ the seven intelligences to present a lesson would be reaching out to far more people in lesser time. Students would definitely prefer such an alternative to the traditional lecture or question-and-answer sessions which tend to be teacher-centered.

In the book, Frames of Mind, Howard Gardner further explains these seven ways as follows:

1. Linguistic Intelligence - the considerable command of the linguistic tetrad of phonology, syntax, semantics, and pragmatics; the four aspects of linguistic knowledge are:

a. Rhetorical aspect - the ability to use language to convince other individuals of a course of action;

b. Mnemonic aspect - the capacity to use this tool to help one remember information ranging from lists of possessions to rules of a game, from directions for finding one's way to procedures for operating a machine;

c. Role in explanation - teaching-learning in language principally through oral instructions, explaining verse through the word in its written form.

d. Explanation of its own activities - the ability to use language to reflect upon language, to engage in meta-linguistic analysis;

2. Musical Intelligence - the ability to understand the special flavor of music and at the same time illustrate its relation to other forms of human intellect; music is the corporealization of the intelligence that is sound; the musical is educated through concerts, raps, mnemonic songs, musically guided imagery, and dance music accompanying performance activities;

3. Logical-Mathematical Intelligence - the ability of the students to reason through the logical basis of the material being studied; this 
thinking can be traced to a confrontation with the world of objects in ordering and recording them and in assessing their quantity;

4. Special-Visual Intelligence - the ability to perceive the visual world accurately, to perform transformations and modifications upon one's initial perceptions, and to be able to recreate aspects of one's visual experience even in the absence of a relevant physical stimuli (e.g., drawings, posters, mind maps, human sculptures);

5. Intrapersonal Intelligence - the development of the internal aspects of a person-one's own feeling of life, one's range of affects or emotions, one's self knowledge and personal styles.

6. Bodily-Kinesthetic Intelligence - the ability that is developed primarily through dance, human sculptures, games, skits, and role plays in which students perform with their whole body or at least manipulate objects symbolizing elements under study;

7. Interpersonal Intelligence - the ability to notice and make distinctions among other individuals; this intelligence is developed through frequent class interaction and discovering both with whole or small groups through think-and-listen (Hoerr).

The short stories and poems selected in this Reader and the strategies outlined here are just a sample of what teachers may choose for their classrooms. Because teachers know their students best, choosing the text and a combination of suitable techniques would ultimately be their decision. 


\section{Notes}

1. Much of the data on the Chinese-Filipino woman is based on the article of Theresa C. Cariño, "Chinese Women in Manila: Changing Roles and Perceptions," in Manila: History, People and Culture. Ancestral worship refers to the Chinese custom of paying respect to one's ancestors. Elaborate rituals are observed during the Ching Ming (the Chinese All Souls' Day) and the dead's birth and death anniversaries. The Chinese believe that through the prescribed rituals, the dead were honored and induced to aid the living.

2. Ancestral worship refers to the Chinese custom of paying respect to one's ancestors. Elaborate rituals are observed during the Ching Ming (the Chinese All Souls' Day) and the dead's birth and death anniversaries. The Chinese believe that through the prescribed rituals, the dead were honored and induced to aid the living. 


\section{Works Cited}

Amyot, Jacques, S.J. The Chinese Community of Manila: A Study of Adaption of Chinese Feminism to the Philippine Environment. University of Chicago, 1960.

Baviera, Aileen S.P., and Teresita Ang See. China Across the Seas. De La Salle UP, 1985.

Cariño, Theresa Chong. China and the Overseas Chinese in Southeast Asia. New Day Publisher, 1985.

"Chinese Woman in Manila: Changing Roles and Perceptions." Manila History, People and Culture, edited by Wilfred V. Villacorta, Isagani R. Cruz, and Ma. Lourdes Brillantes, De La Salle UP, 1989, pp. 145-159.

Clayre, Alasdair. The Heart of the Dragon. Houghton Mifflin Co., 1984.

Collie, Joanne, and Stephen Slater. Literature in the Language Classroom. Cambridge UP, 1987.

Commission on the Status of Women. The Role of Women in the Philippines. Commission on the Status of Women, 1975.

Disnon, Dee, and Pat O'Leary. A Guidebook for Cooperative Learning: A Technique for Creating More Effective Schools. Learning Publications Inc., 1984.

Douglas, Robert K. Society in China. A.D. Innes and Co., 1894.

Gardner, Howard. Frames of Mind. Basic Books, 1985.

Gray, John Henry. China - A History of the Laws, Manners and Customs of the People. Irish UP, 1972.

Hoerr, Thomas R. "Becoming a Multiple Intelligences School," ASCD, http://www. ascd.org/publications/books/100006/chapters/The-Theory-of-MultipleIntelligences.aspx

Lai, T.C Things Chinese. Swindor Book Co., 1971.

Latourette, Kenneth Scott. The Chinese - The Stories and Culture. McMillian Co., 1964.

Liao, Shubert S. C., editor. Chinese Participation in Philippine Culture and Economy. By the Author, 1964.

Lim, Benito. “The Burial.” Sunday Times Magazine, 17 July 1968, pp. 42-48.

Lim, Ma. Fatima V. Wandering Roots/From the Hothouse. Anvil Publishing, 1991.

Lin Yu Tang. My Country and My People. John Day Co., 1939.

Maria Katherine. Reading Comprehension and Instruction: Issues and Strategies. New York P, 1990.

McCarthy Charles, S.J. Philippine-Chinese Integration. Pagkakaisa sa Pag-unlad Inc., 1971.

McCarthy Charles, S.J. Philippine-Chinese Profiles -- Essays and Studies. Pagkakaisa sa Pag-unlad Inc., 1973. 
Moore, Charles, editor. The Chinese Mind - Essentials of Chinese Philosophy and Culture. U of Hawaii P, 1967.

Ong, Charlson. Women of Am Kaw and Other Stories. Anvil Publishing, 1992.

Ornstein, Allan C. Strategies for Effective Teaching. Harper and Row Publishers, 1980.

Philippine Chinese Historical Association. The Annals of Philippine Chinese Historical Association. Philippine Chinese Historical Association, 1970.

See, Chin Ben. The Chinese Immigrants. Kaisa para sa Kaunlaran and De La Salle UP, 1992.

See, Chin Ben See and Teresita Ang See. Chinese in the Philippines: A Bibliography. De La Salle UP, 1990.

See, Teresita Ang, and Lily T. Chua, editors. Crossroads: Short Essays on ChineseFilipinos. Kaisa para sa Kaunlaran, 1988.

Snow, Helen Foster. Women in Modern China. Mountain and Co., 1967.

UP Filipino-Chinese Students' Association. A Reader on the Philippine Chinese. UP Filipino-Chinese Students' Association, 1970.

Van Brevern, Marilies. Once a Chinese, Always a Chinese? The Chinese of ManilaTradition and Change. Lyceum P, 1988.

Welty, Paul Thomas. The Asians - Their Heritage and their Destiny. Charles E. Tuttle Co., 1970.

Williams, C.A.S. Outlines of Chinese Symbolism and Art Motives. Kelly and Walsh, Ltd., 1972.

Yu, Doreen. “Anais.” Focus Philippines, 21 Aug 1976, pp.20-21, 24-45, 28-29.

Yutang, Lin. My Country and My People. William Heinemann Ltd., 1936.

\section{Works Consulted}

$\mathrm{Au}, \mathrm{Hu}$-Pei Kathryn. "Using the Experience-Text-Relationship Method with Minority Children.” The Reading Teacher, vol. 32, no. 6, 1979, pp. 677-679.

Gardner, Howard. Frames of Mind: The Theory of Multiple Intelligences. Basic Books, 2004.

Hall, Mary Anne. The Language Experience Approach for Teaching Reading: A Research Perspective. International Reading Association, 1978.

Langer, Judith A. "From Theory to Practice: A Pre-Reading Plan." ERIC ED, 1980, https://eric.ed.gov/?id=ED197283

Rigg, P. "Beginning to Read in English the LEA Way." Reading English as a Second Language: Moving from Theory, edited by C.W. Twyford, W. Diehl, and K. Feathers, Monographs in Language and Reading Studies, Indiana UP, 1981, pp. 81-90.

Robinson, F.P. Effective Study. Harper \& Row, 1946. 
Rumelhart, David E. and James L. McClelland. "Interactive Processing Through Spreading Activation." Interactive Processes in Reading, edited by Alan M. Lesgold and Charles A. Perfetti, Lawrence Erlbaum Associates Publishers, 1981, pp. 37-60.

Smith-Burke, M.T. "Extending Concepts through Language Activities." Reader meets Author/Bridging the Gap, edited by J.A. Langer and M.T. Smith-Burke, 1980, pp. 163-179.

Stauffer, R. G. Directing Reading Maturity as a Cognitive Process. Harper \& Row, 1969. 



\section{About the Author}

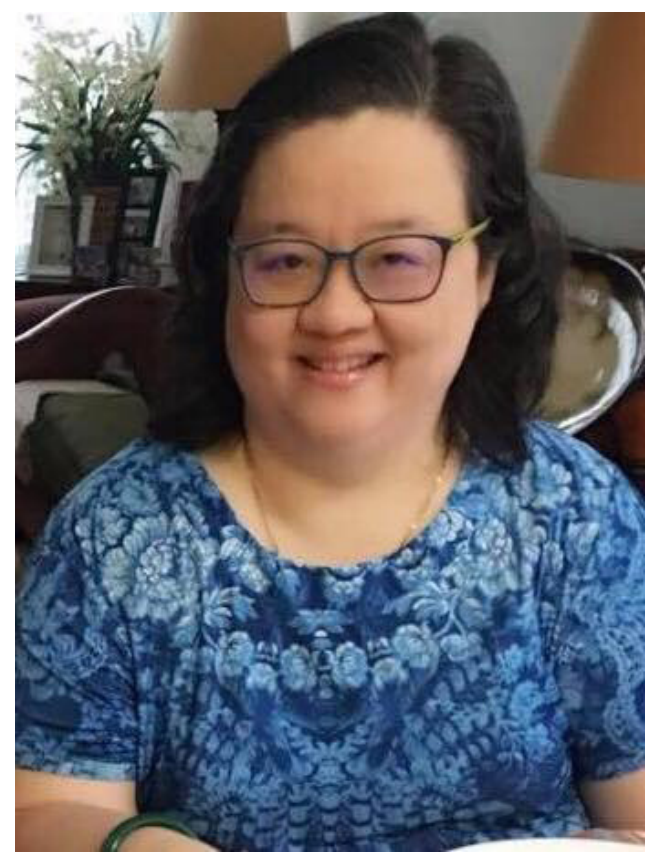

MARY JENNIFER QUE received her Bachelor of Arts and her Master of Arts in Literature from the Ateneo de Manila University and a Specialist Certificate in Materials Design and Development from the Regional Language Centre in Singapore. She taught English at the Immaculate Conception Academy in Greenhills and at the Ateneo in the undergraduate and graduate levels. She was also a teacher-trainer for the Ateneo Center for English Language Teaching and taught EFL at the Ateneo Language Center. She currently teaches at Pasadena High School, a National Model School in Pasadena, Texas. 